University of Rhode Island

DigitalCommons@URI

Open Access Master's Theses

1984

\title{
A Real Estate Development Plan for the Bancroft-Rice School Site Boston, Massachusetts
}

Margaret A. Barringer

University of Rhode Island

Follow this and additional works at: https://digitalcommons.uri.edu/theses

\section{Recommended Citation}

Barringer, Margaret A., "A Real Estate Development Plan for the Bancroft-Rice School Site Boston, Massachusetts" (1984). Open Access Master's Theses. Paper 617.

https://digitalcommons.uri.edu/theses/617

This Thesis is brought to you for free and open access by DigitalCommons@URI. It has been accepted for inclusion in Open Access Master's Theses by an authorized administrator of DigitalCommons@URI. For more information, please contact digitalcommons-group@uri.edu. 


\title{
A Real Estate Development Plan for the Bancroft-Rice School Site Boston, Massachusetts
}

\author{
By \\ Margaret A. Barringer \\ A RESEARCH PROJECT SUBMITTED IN \\ PARTIAL FULFILLMENT OF THE REQUIREMENTS \\ FOR THE DEGREE AND MASTER OF \\ COMMUNITY PLANNING
}
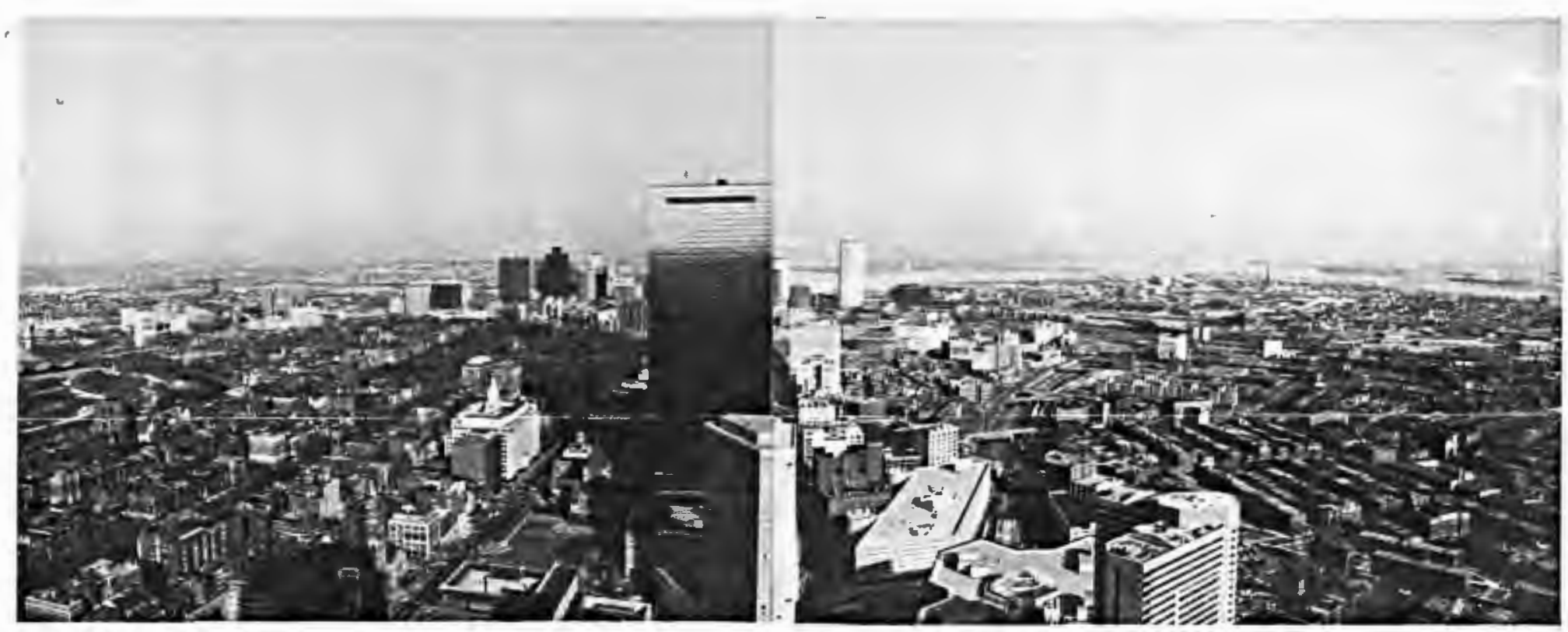

UNIVERSITY OF RHODE ISLAND 


\section{MASTER OF COMMUNITY PLANNING RESEARCH PROJECT \\ OF \\ MARGARET A. BARRINGER}

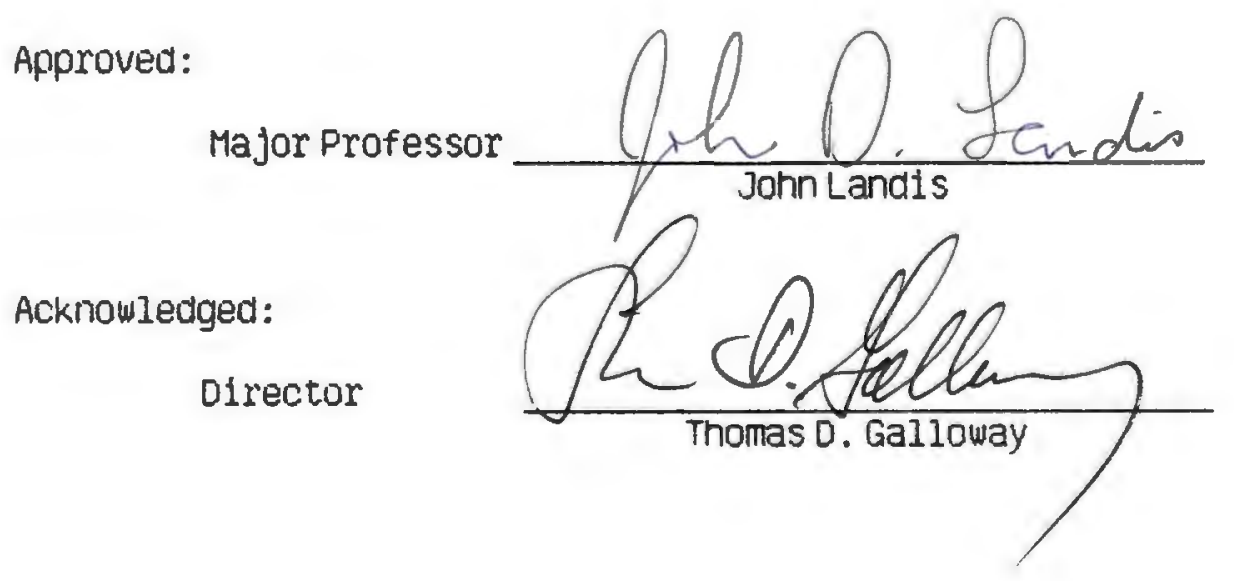




\section{Table of Contents}

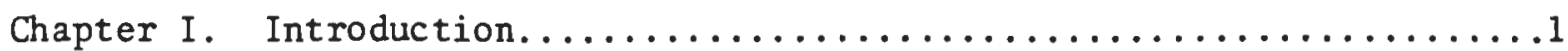
Synopsis

Chapter II. Site Analysis................................... Description of the Site

Condition

Selling Price

Chapter III. Market Analysis...............................

A. Indirect Economic Influences $\ldots \ldots \ldots \ldots \ldots \ldots \ldots \ldots \ldots \ldots \ldots$ Location Character of the Immediate Area Transportation Linkages

Parking Access to Services Existing Regulations Points of Interest

B. Direct Economic Influences............................. 22 Description of the Market Area Population Market Conditions Recent Development Projected Housing Demand Competing Housing Projects

C. Market Analysis Sumnary...Parameters for Optimum Development..................................43

Chapter IV. Description of the Project....................... 45

A. Basic Development Alternative - Residential Condominiums......45 Layout Condominium Units Amenities and Special Features External Renovation Price Construction Cost Financing

B. Alternative Development Option - First Floor Offices..........56 Suitability of Office Use Investment Tax Credit

Size Number of Units Liquidation 
C. Additional Consideration - Decreased Down Payment Requirement for Condominium Purchasers .......................57

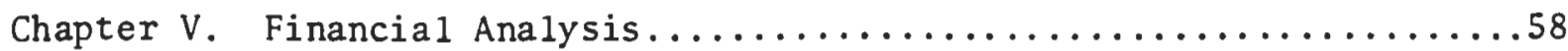

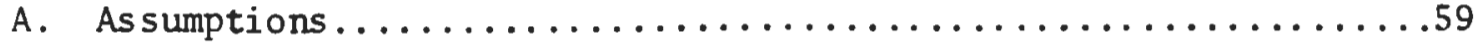

B. Basic Development Alternative - Residential Condominiums Only..61 Description of Scenarios

C. Findings: Basic Development Alternative - Residential

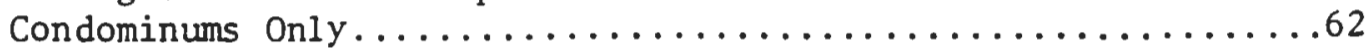
Scenario Pro Formas

D. Alternative Development Option - Condominiums with First Floor offices................................ Description of Scenarios

E. Findings: Alternative Development Option - Condominiums with First Floor offices......................... Residential Condominium Segment Office Segment Scenario Pro Formas Total Project - Residential Condominiums and Offices

F. Developer Assisted Mortgage Financing................

G. Final Recommendation for Optimum Development............90

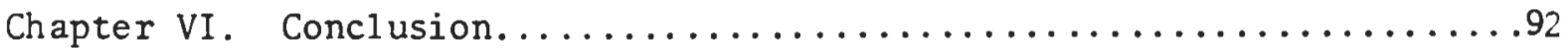

Financial Benefit to the Investor

Total Benefit to the City of Boston

Summary

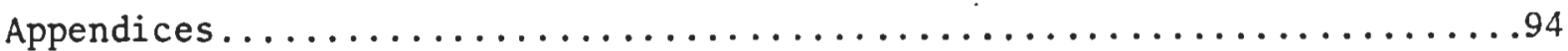

A. Regulation of Uses: $\mathrm{H}$ Zoning District..................

B. Dimensional Regulations........................

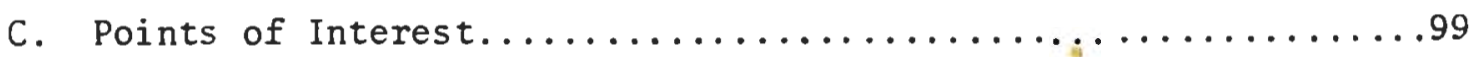

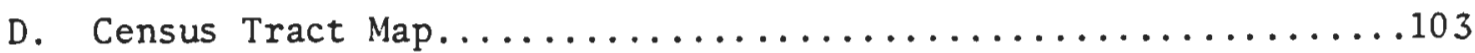

E. Fiscal Impact Analysis .........................

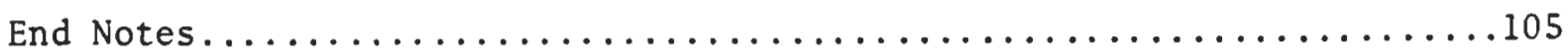

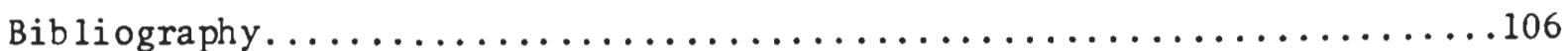




\section{List of Figures}

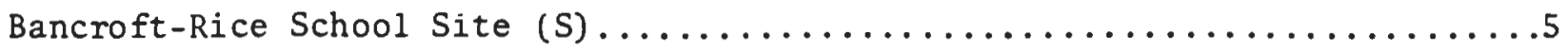

Bancroft-Rice School Site and Surrounding Area $(\mathrm{M}) \ldots \ldots \ldots \ldots \ldots \ldots \ldots$

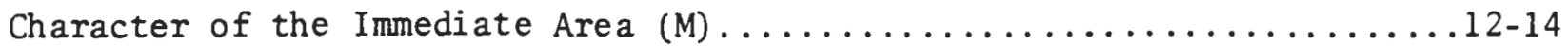

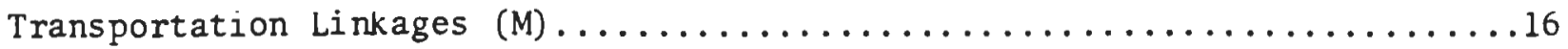

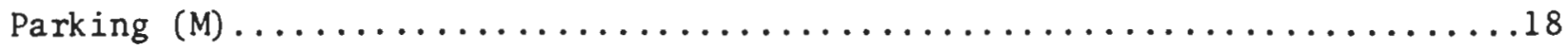

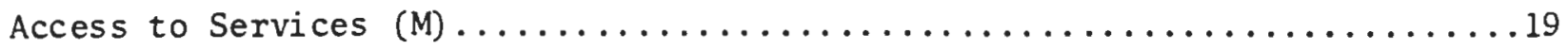

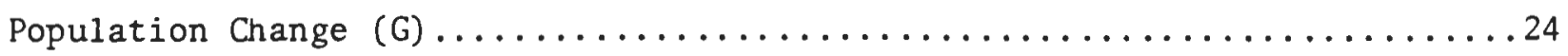

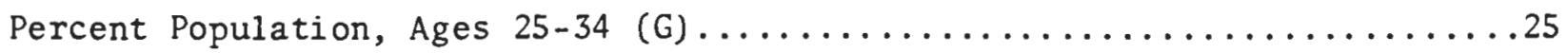

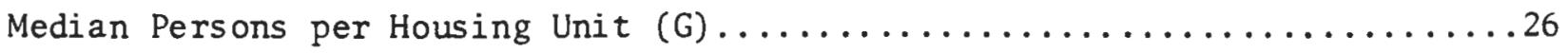

Income, Ability to Afford High Quality Housing (G) $\ldots \ldots \ldots \ldots \ldots \ldots \ldots . . \ldots 27$

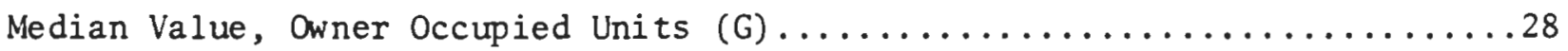

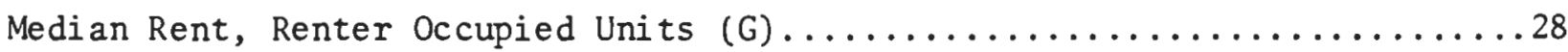

Housing Construction, Census Tract, City, and SMSA (G) $\ldots \ldots \ldots \ldots \ldots \ldots 29$

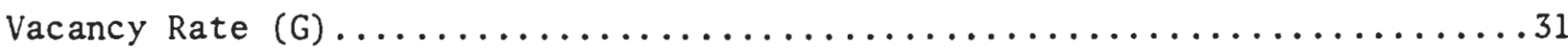

Comparable Condominium Sales Data (T) ........................ 34-35

Square Feet - Price, Comparable Condominiums $(G) \ldots \ldots \ldots \ldots \ldots \ldots \ldots \ldots \ldots$

Price - \# of Bedrooms, Comparable Condominiums (G) .................. 36

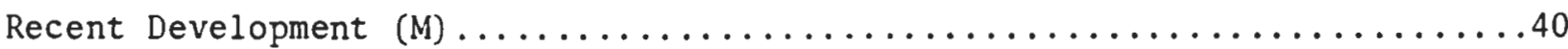

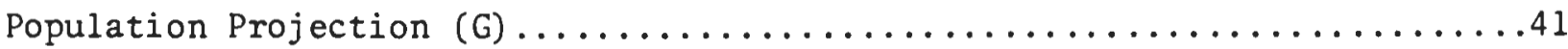

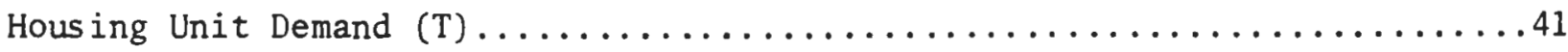

Rice Building, Layout and Unit Prices $(\mathrm{S}) \ldots \ldots \ldots \ldots \ldots \ldots \ldots \ldots \ldots$

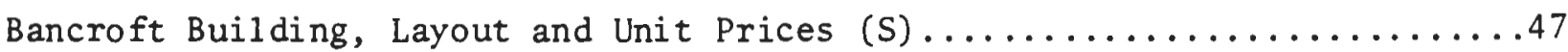

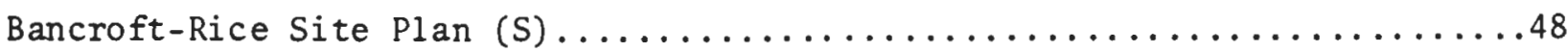


Bancroft Rice Site Plan and Elevation Drawing (S) ...............50

Renovation Cost Estimate $(\mathrm{T}) \ldots \ldots \ldots \ldots \ldots \ldots \ldots \ldots \ldots \ldots \ldots \ldots \ldots . \ldots \ldots$

Basic Development Alternative - Residential Condominiums Only,

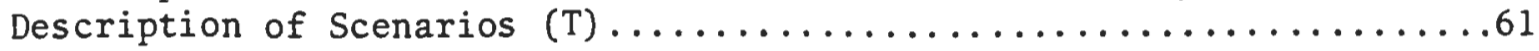

Basic Development Alternative, Summary of Key Indicators $(\mathrm{T}) \ldots \ldots \ldots \ldots 62$

Residential Condominiums Only, Pessimistic, Moderate and Optimistic

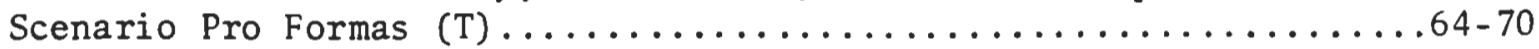

Alternative Development Option - Condominiums with First Floor

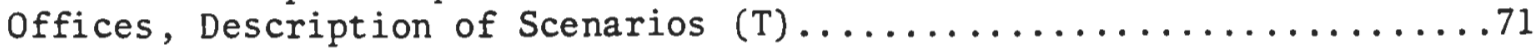

Alternative Development Option, Residential Segment Summary of Key

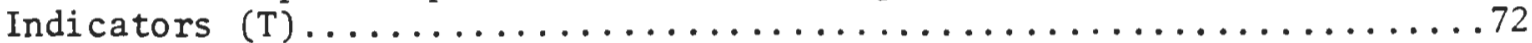

Alternative Development Option, Office Segment, Summary of Key

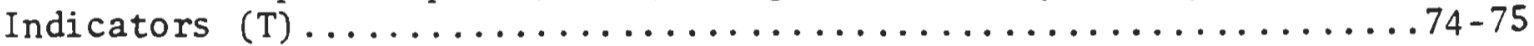

Condominiums with First Floor Offices, Pessimistic, Moderate and Optimistic Scenario Pro Formas (T) ...................

Alternative Development Option, Total Project, Summary of Key

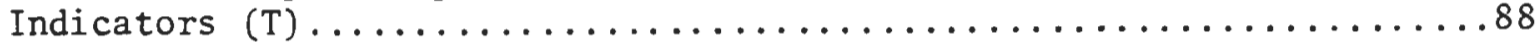

Summary of Key Indicators, Comparison of Both Development Alternatives (T).90 G - Graph
$M$ - Map
T - Table
S - Sketch or sketch Plan 


\section{Chapter I Introduction}

\author{
This paper focuses on a single \\ real estate development project in \\ Boston, Massachusetts. It is composed \\ from the perspective of a consultant \\ working for a private developer or \\ real estate trust, charged with the \\ duty of examining investment opportun- \\ ities and providing recommendations. \\ The presentation format parallels that \\ of a prospectus which thoroughly re- \\ searches and analyzes the site to re- \\ veal its development potential for \\ varied types of investors.
}

The Bancroft-Rice School was chosen as the subject of research for two reasons. The first is because it exhibits significant potential for redevelopment. The school buildings, although recently fallen into disrepair, are impressive examples of French Academic architecture, quite uncommon in Boston's South End. It is also one of the few sites in the urban area with existing on-site parking. The school is excellently located within a short distance from the fashionable Back Bay District, in an area which is beginning to experience considerable reinvestment. In addition, the recently completed Copley Place mixed ise project, situated only two blocks iway, compounds the site's potential value. The proximity to work centers and access to retail, transportation, sultural and recreational facilities further expands the opportunities for successful adaptive reuse.

The second reason for studying the Bancroft-Rice property is because the disposition of public buildings, particularly schools, is becoming more and more common. The City of Boston recently placed nine schools on the market, while other communities have also begun selling their surplus properties.
Tremendous development opportunities can be realized pending favorable agreements between municipalities and developers. The presentation of a financially sound project with community benefits outweighing public costs can often result in a reduced selling price, making the project economically very attractive.

\section{Synopsis}

I have set out to accomplish five basic tasks: site description, market analysis, formulation of viable development alternatives, complete financial analysis, and final recommendation for optimum development of the site. These tasks correspond to the five following chapters which are briefly summarized below.

Chapter II. Description of the Site. A detailed examination of the site is presented including a discussion of the architecture, size, condition and selling price of the buildings. This chapter also includes a sketch plan and photographs to illustrate the appearance and physical layout.

Chapter III. Market Analysis. This chapter is organized into two parts. The first section carefully explores the indirect economic forces affecting potential development. This investigation is generally focused on the ever import locational factors (ie. character of the area, access to services, parking, etc) as well as existing building and zoning regulations. Immediately these indirect influences begin to eliminate certain development options while indicating an increased potential for others. The primary suitable use identified for the area is residential with the possibility for a minor office component. 
The second part of the chapter then analyzes the direct economic forces affecting supply and demand to further specify the highest and best use of the property. Census information at three levels, census tract, city wide, and SMSA is used to analyze current trends indicating housing demand, and also to identify the target population. Recent sales data allows the identification of the most marketable types, sizes, and prices of housing units as well as the most popular amenity features. This combination of information presents a true picture of current housing demand. The following examination of development currently underway and existing housing supply allows the projection of the estimated future residential demand and determines the marketability of the new units. The chapter concludes with a summary of market analysis findings and the resulting suggested parameters for optimum development of the site.

Chapter IV. Description of the Project. The suggested parameters are employed in this chapter to formulate two development alternatives. The first is an entirely residential condominium development. The second alternative is also primarily residential condominiums, but also contains professional offices on the first floor of both buildings. A complete description accompanies each alternative including the sizes, prices, and amenities of the units, as well as the financing arrangements and detailed cost estimate. Sketch plans and elevation drawings are also included to illustrate the proposed layout of the buildings and parking lot.

Chapter V. Financial Analysis. The financial feasibility of both development alternatives is thoroughly analyzed in this chapter. Three scenarios varying from most optimistic to "worst case" are detailed for each alternative. They differ in selling rate, price, rent, lease up period, and construction cost. Computer spread shéet models developed for the two alternatives are then used to test the varying scenarios, determining the sensitivity of these variables with regard to their effect on the financial success of the project. The key indicators used to indicate the measure of success are: Total Discounted Return After Taxes, Net Present Value of Profit, Return on Investment After Taxes, Internal Rate of Return and Investment Value.

This chapter also examines the possibility of developer assisted mortgage financing. As determined by the market analysis, a large percentage of the target population has the income necessary for mortgage payments but not the savings for a down payment. Therefore, reducing the initial equity requirement may greatly increase the sales appeal of the units. The cost of this type a buy down is weighed against the benefits of a potentially shortened selling time. The Total Discounted Return After Taxes resulting from varying selling periods is examined. This indicates the potential value of having the units sell more quickly and suggests a dollar amount parameter for investment in a buy down of this type.

The chapter concludes with the comparison of the two development alternatives. Each option is evaluated with regard to the differing needs of individual investors.

Chapter VI. Conclusion. Finally, the conclusion is presented in two parts. The first summarizes the analyses conducted, reiterates the recommendations for optimum development of the site and indicates the types of investors which would most likely gain from investment in the project. The second part focuses on how the project would benefit the 
City of Boston. This is particularly important because the site is being sold at the City's discretion and it will be necessary to prove that the financial revenues and other advantages outweigh the public costs incurred. The results of a fiscal impact analysis are presented with other supporting information illustrating the lasting value of the project. 


\section{Chapter II}

\section{Site Analysis}

\section{Description of the Site}

The Bancroft-Rice School is composed of two structures existing on a lot of just over one acre of land $(45,579 \mathrm{sq}$. feet). Approximately two thirds of the site is a paved parking area which surrounds the buildings. The largest structure, the Rice Building, totals 40,520 square feet of floor space. It was constructed in 1869 and designed in the French Academic tradition by the prominent Boston firm of Emerson and Fehner. 1 The building illustrates many attractive characteristic elements of the style: the symmetrically organized facade, sculptural window enframents and mansard roof. The smaller structure, the Bancroft building, is comprised of 22,480 square feet of floor space and dates from 1870. It is somewhat less architecturally interesting than the Rice, although its design is similar and does possess aesthetic merit.

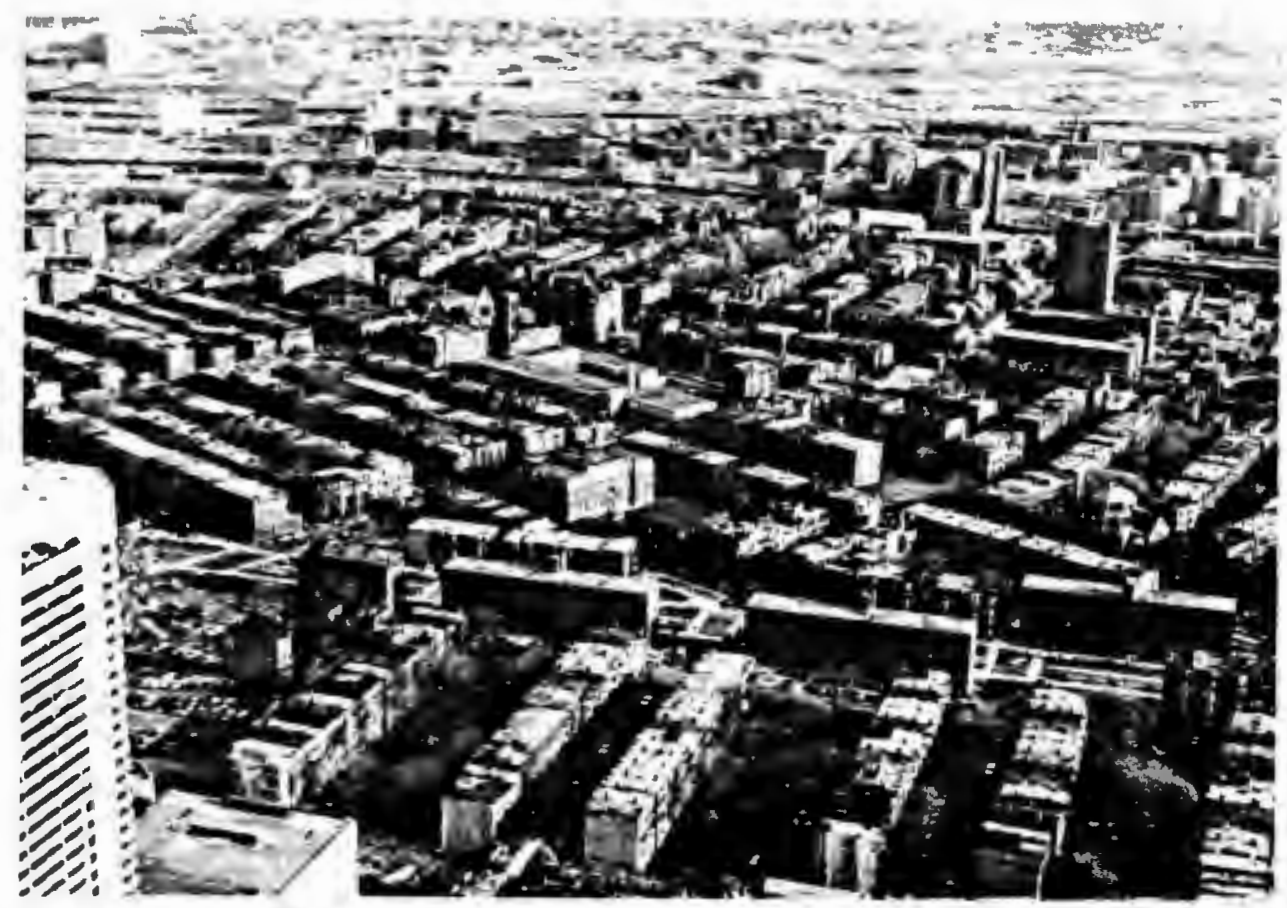

SOUTH END (Bancroft-Rice Site at center of photograph) 


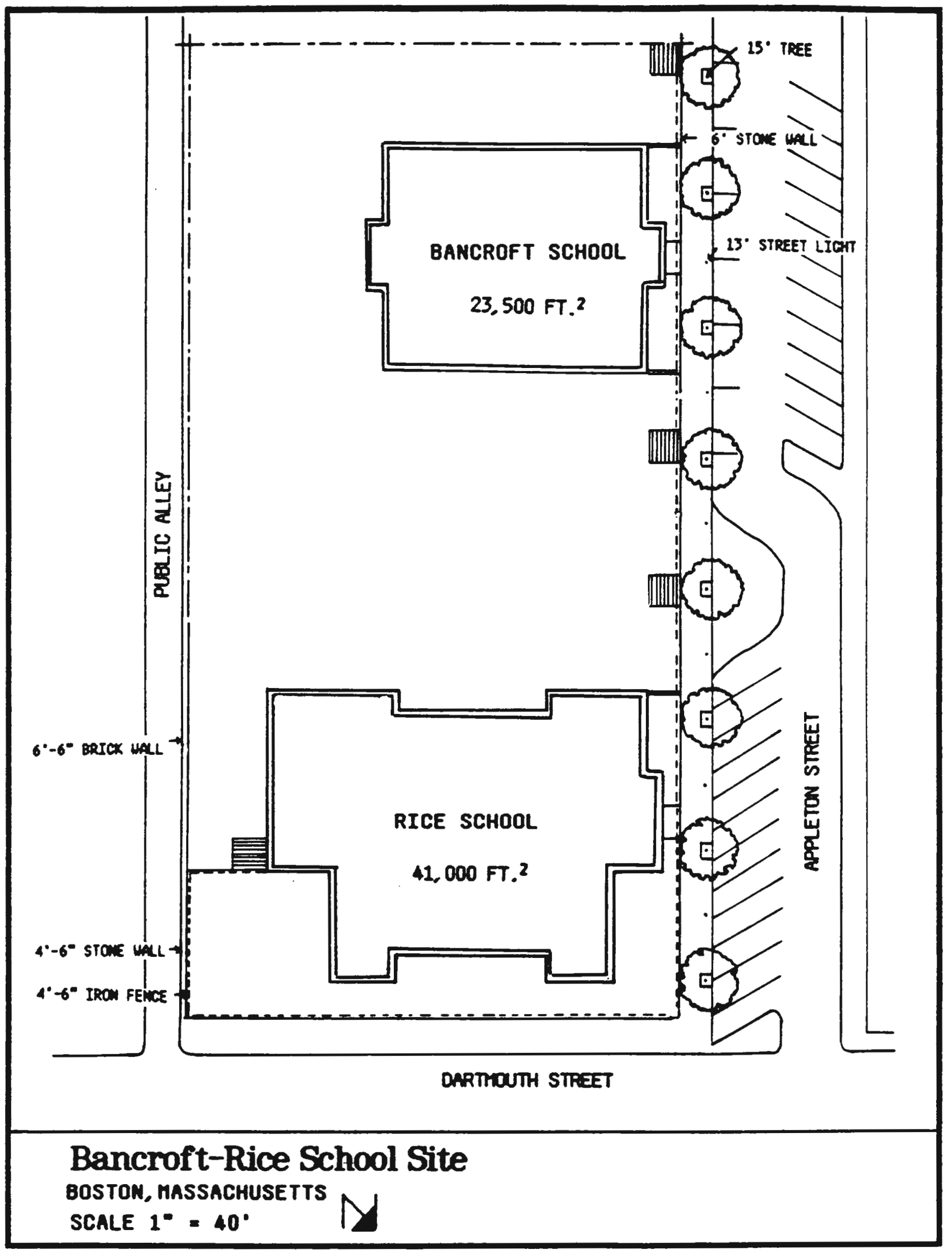




\section{Condition}

The Bancroft-Rice School was closed in July, 1981 and has been vacant and subject to vandalism since that time. The exterior appearance of both buildings is poor. Extensive renovation is needed to restore the facades to near their original beauty.
Necessary exterior rehabilitation would include: cleaning and treatment of masonry, replacement of all windows, repair of .window and door enframents, and repair and cleaning of the mansard roof. Although maintenance needs have been neglected in recent years, the buildings remain is relatively sound structural condi-

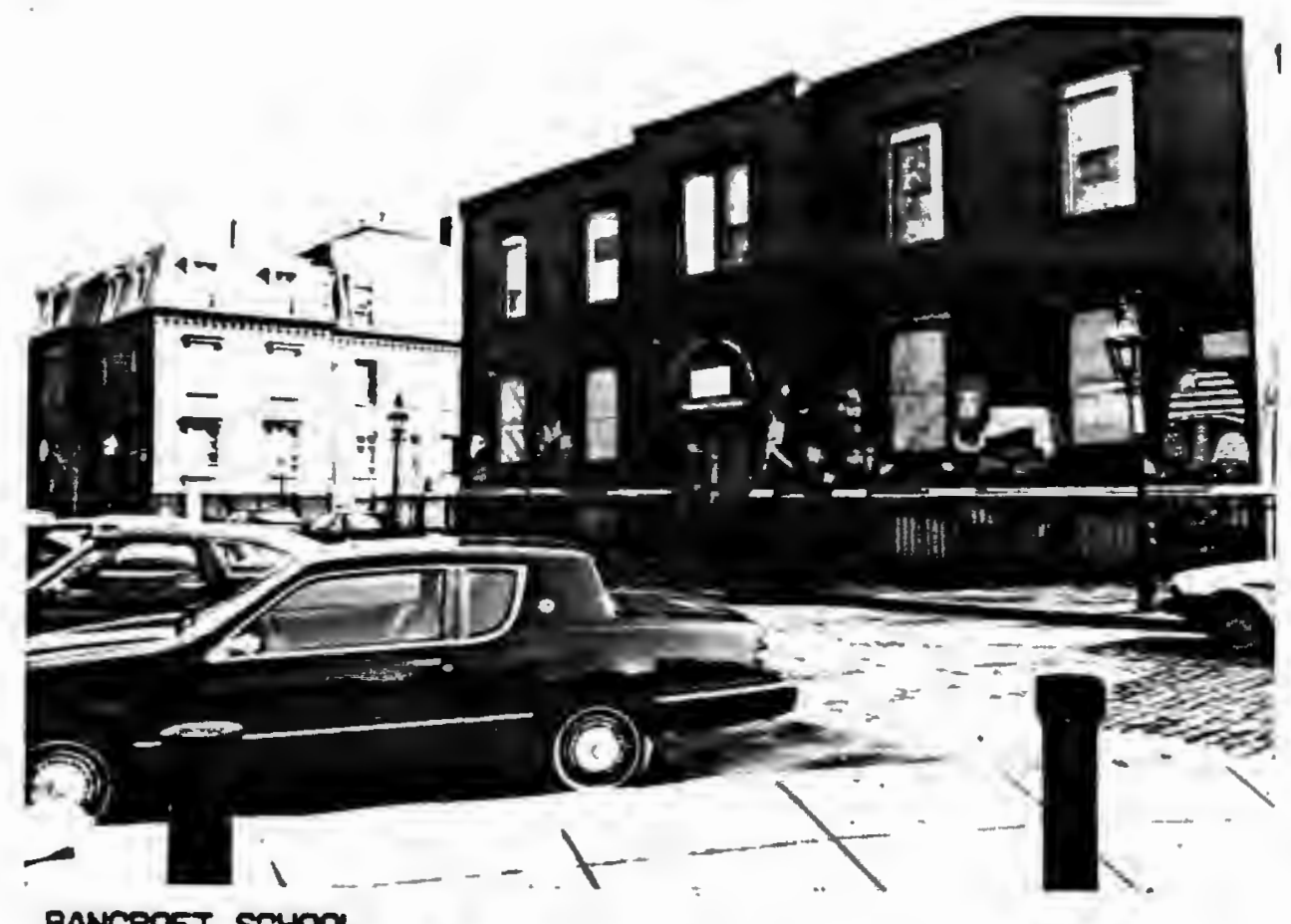

BANCROFT SCHOOL

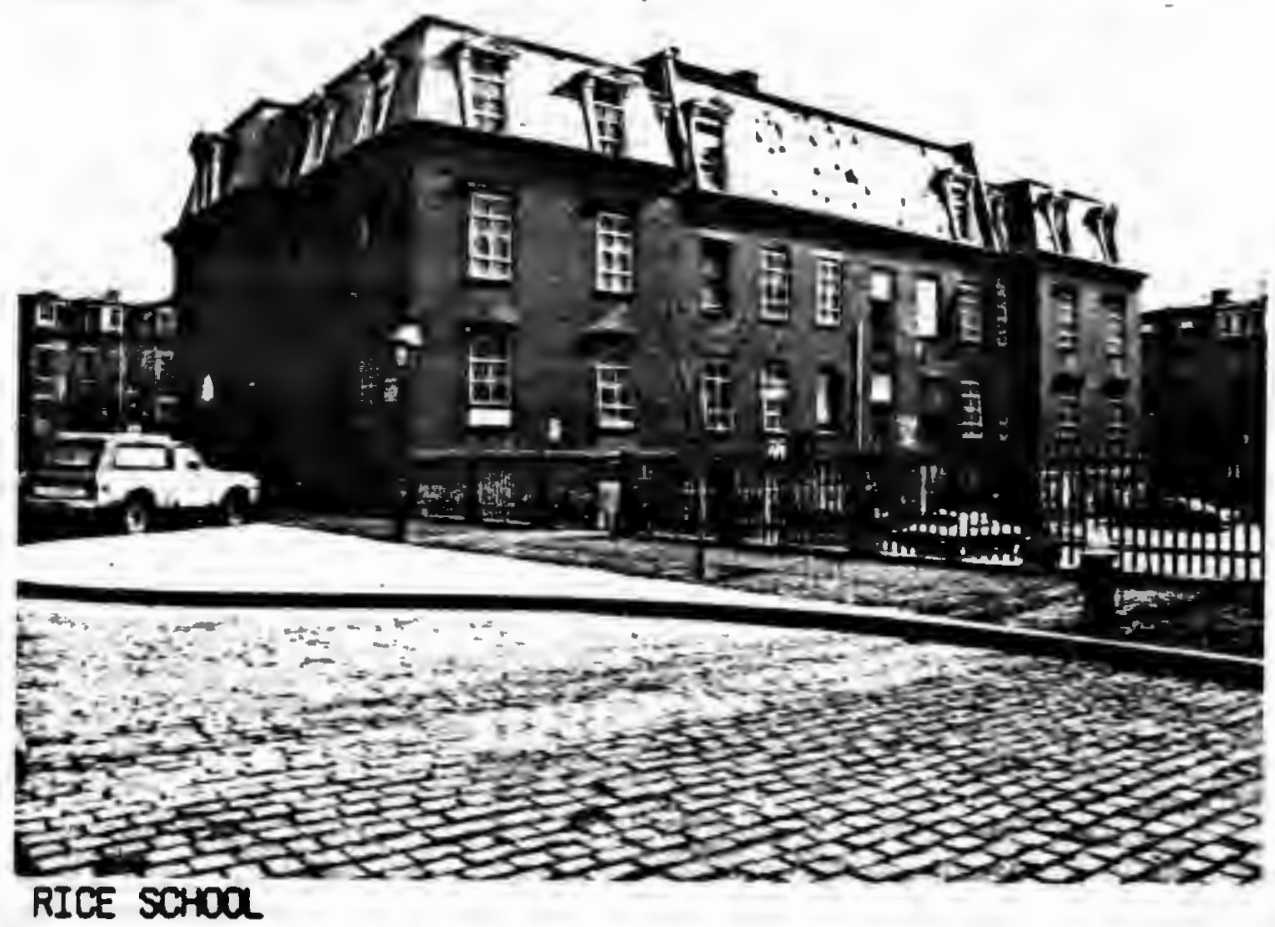


tion and would be well worth the renovation efforts suggested. The interior structure would also require alteration, the extent of which is dependent on the proposed use. Plumbing, heating, air conditioning and electrical systems would need complete revamping in addition to any other customizing work necessary to accomodate the new use.

\section{Selling Price}

The current selling price for the property is $\$ 265,000$. The school is to be packaged with two other schools which offer less attractive development opportunities. Prospective developers wishing to purchase the Bancroft-Rice School must also purchase the other two sites. However, for the purpose of this analysis, the Bancroft-Rice property will be viewed independently as a single development project. At the conclusion of the study, the results of the feasibility analysis may be tempered in light of the requirement to purchase all three

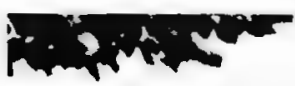
schools.

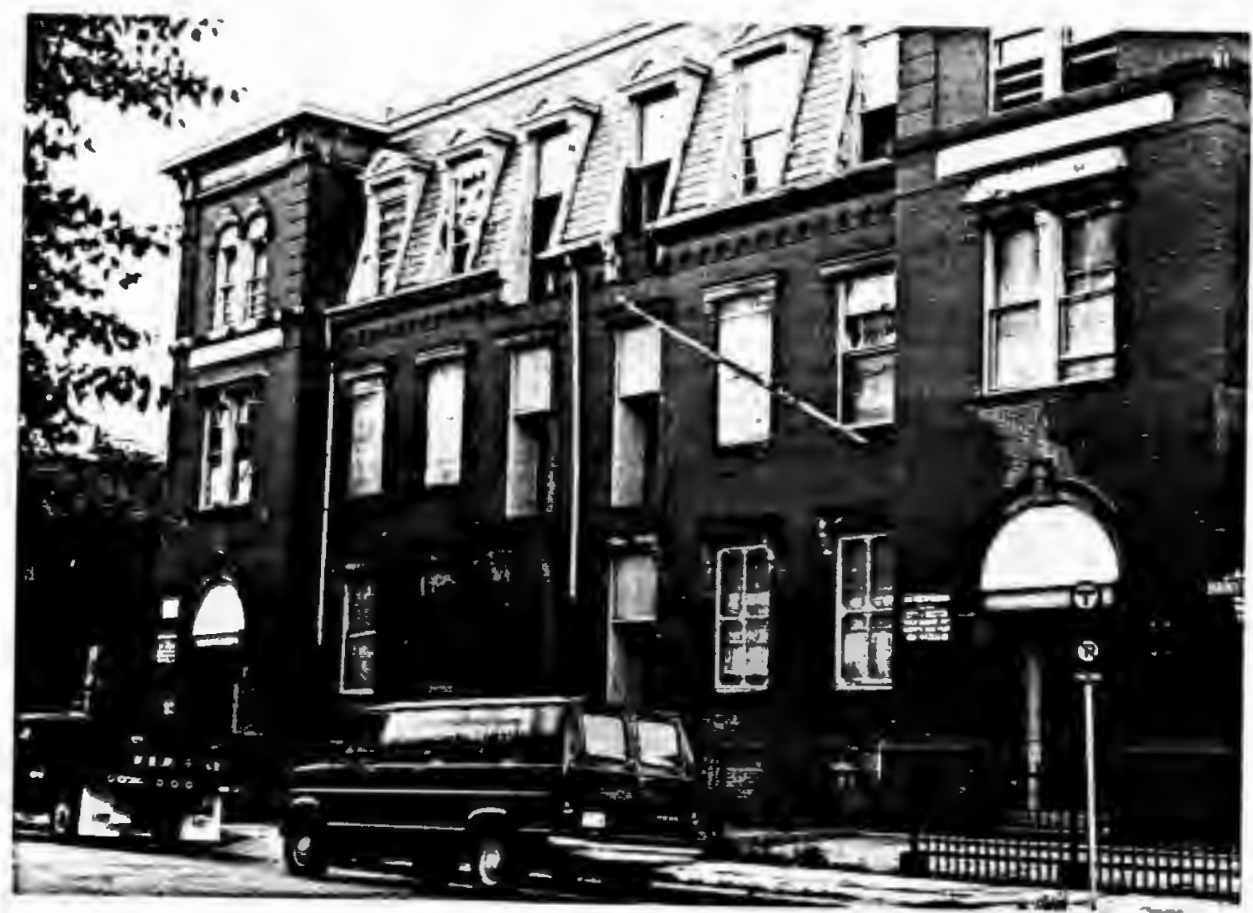




\section{Chapter III}

\section{Market Analysis}

The market analysis is accomplished in two steps. First, the indirect economic influences which begin to suggest suitable uses for the site are explored. This includes locational factors such as proximity to services and character of the area as well as existing building and zoning regulations. Secondly, after the most appropriate general uses have been cited, the direct economic influences are examined in detail. The forces of supply and demand are examined to yield the best estimate of market conditions. The conclusion of the chapter utilizes the results of the market study to identify parameters for the optimum development of the site.

\section{A. Indirect Economic Influences}

All indirect economic influences are examined at the onset of the market analysis. These factors instant$1 y$ begin to eliminate certain development alternatives while illustrating an increased potential for others. These influences are investigated under the following topics:

Location, the general description and background information concerning the neighborhood,

Character of the Immediate Area, an indication of the visual impression the area projects,

Transportation Linkages, an illustration of the site's accessibility to employment, retail and residential centers,

Parking, a description of the location, quantity and type of parking available to potential site users,

Access to Services, the proximity to commercial, cultural and recreational facilities,

Existing Regulations, the limitations on potential uses and restrictions affecting building expansion or alteration,

AND

Points of Interest, an identification of significant sites which exert an attracting force on potential development. 


\section{Location}

The Bancroft-Rice site is located on Appleton Street at the intersection of Dartmouth Streez in Boston's Historic South End. The area is predominantly residential with a limited number of small first floor retail establishments and occasional offices. To understand the composition of this neighborhood, it is necessary to examine its developmental history. This city neighborhood developed primarily between 1850 and 1870 as a fashionable residential quarter. Three and four story brick townhouses with swell-fronts, mansard roofs, high stoops and black iron railings 1 ined the streets. The area prospered and grew until the turn of the century. At that time the neighborhood began to decline. After wealthy residents abandoned the area, most large homes were converted to rooming houses and apartment buildings, housing poor immigrants. The crime rate rose sharply in the following years hastening the South End's decay.

Redevelopment efforts began in the 1960's and can be viewed as having occurred in two phases. The first phase benefited the low income residents who remained in the South End after the middle class exodus to the surrounding suburbs. Subsidized housing and other publicly aided projects helped to rejuvenate the area for its current population.

The second phase of redevelopment began in the late $70^{\prime} \mathrm{s}$ and has continued into the $80^{\prime} \mathrm{s}$, coinciding with the renewed desire on the part of the middle and upper class to live within the City, and the redevelopment of the adjacent Back Bay District. Many areas of the South End, particuularly those at the fringe of the Back Bay, have experienced redevelopment, generally of the small scale, building by building type. These private efforts are geared to attract middle and upper income residents into the area, an objective quite different from that of the first redevelopment phase.

It is helpful to note that most of the phase one type redevelopment has occurred in the Southern - most section of the South End and most of the phase two type has occurred in the Northern - most section bordering Back Bay. In between these two areas and within them as well, rows of original townhouses from the $1850^{\prime} \mathrm{s}$ and $60^{\prime} \mathrm{s}$, primarily used for rental housing, remain potential targets for redevelopment .

The Bancroft-Rice School is 10cated in the Northerly section of the South End as illustrated on the following map. This map as well as others depicting neighborhood influences, shows a significant portion of Back Bay, as the site's proximity to this prestigous residential, commercial and cultural center has a large impact on its desirability. Back Bay's Victorian buildings, brick sidewalks and historic lighting have created an impressive neighborhood attracting many residents who can affort its high prices and disappointing those who cannot. The logical spillover area for those wishing proximity to the elegance of high quality galleries, specialty shops, hotels and restaurants, but finding Back Bay unattainable, is the adjacent South End, lending greater potential to the BancroftRice School location. Further, the site is only $1 \frac{1}{2}$ blocks from the new Copley Place Development with its mix of hotels, offices and retail estab1 ishments. 


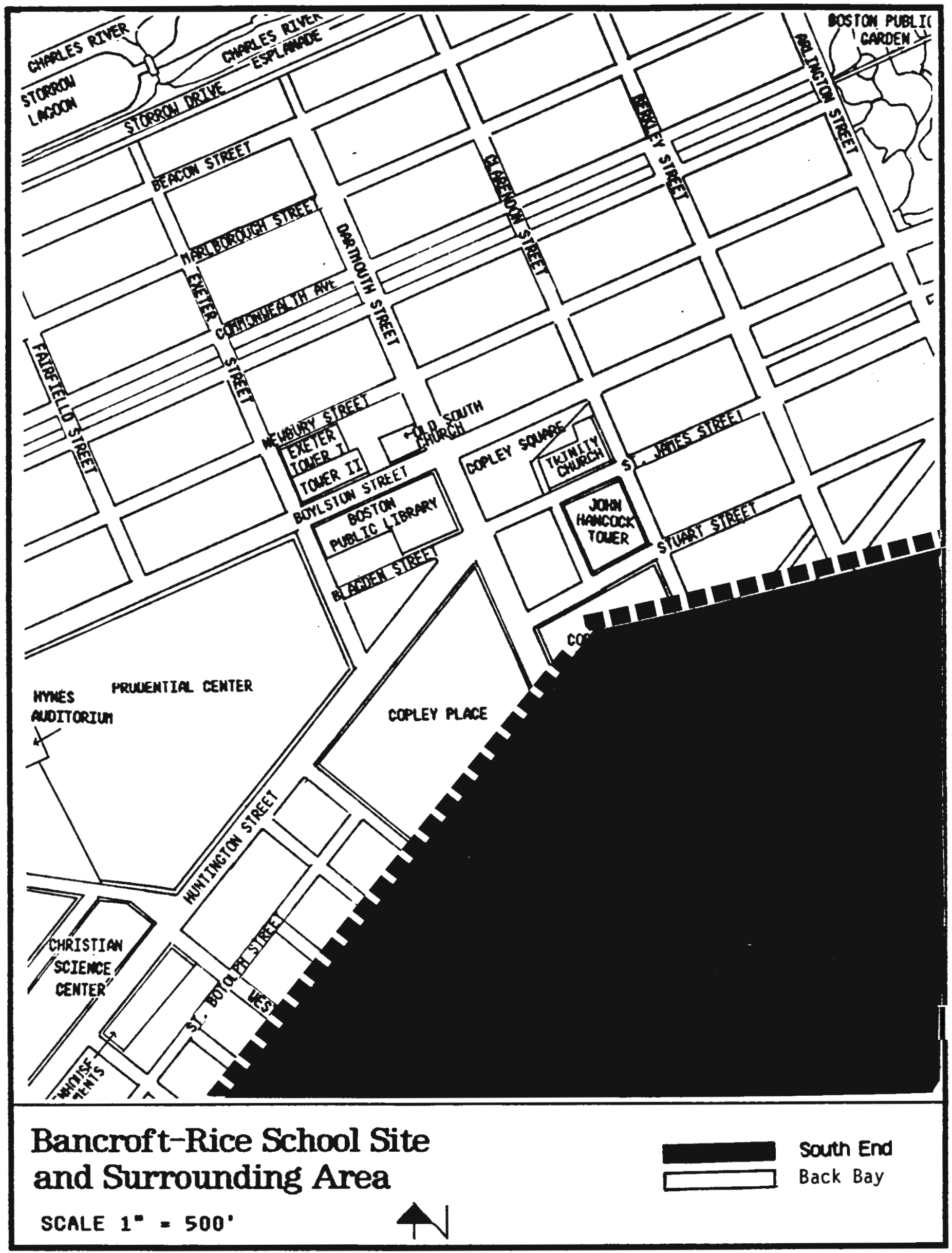



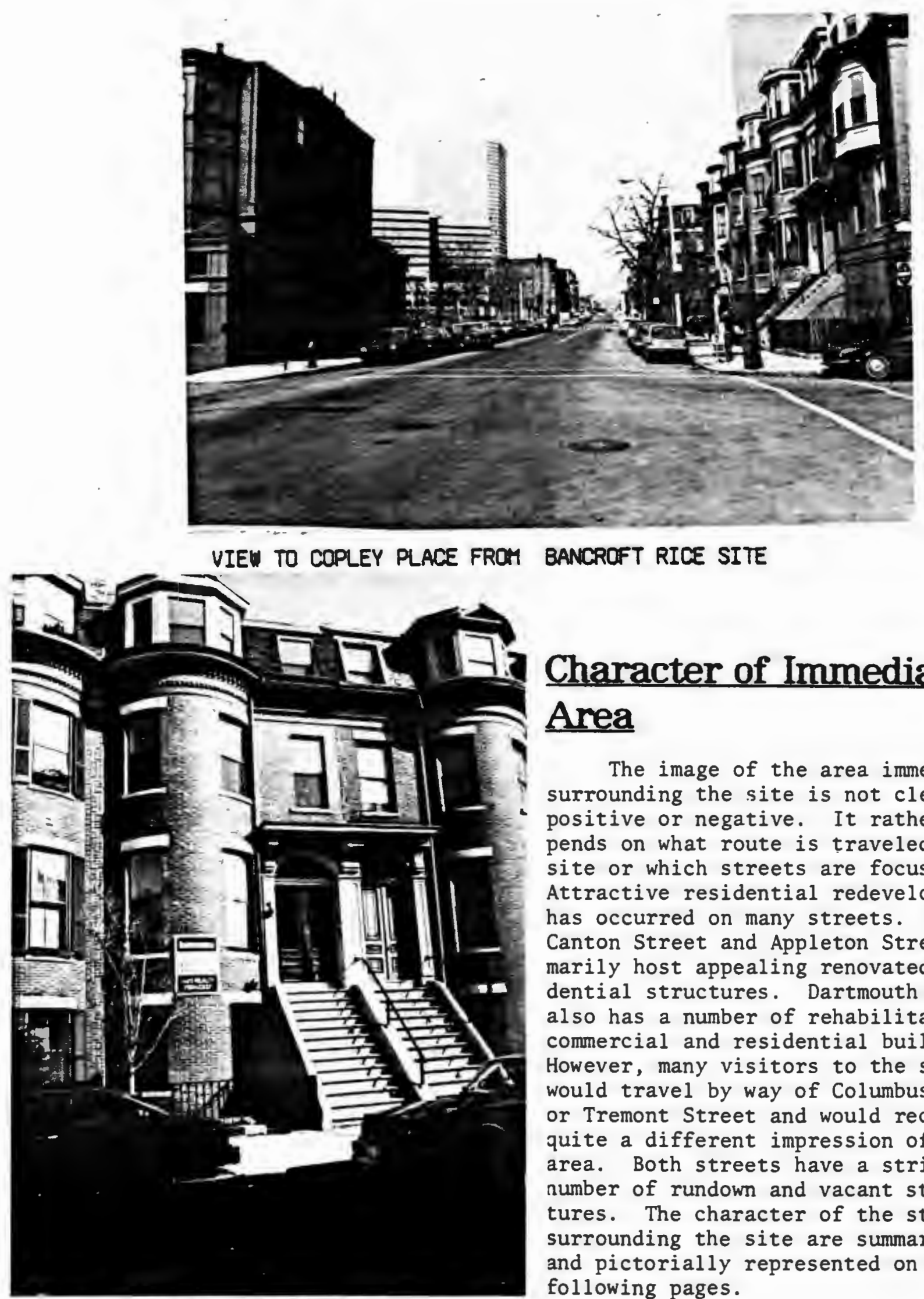

BANCROFT RICE SITE

\section{Character of Immediate Area}

The image of the area imnediately surrounding the site is not clearly positive or negative. It rather depends on what route is traveled to the site or which streets are focused upon. Attractive residential redevelonment has occurred on many streets. West Canton Street and Appleton Street primarily host appealing renovated residential structures. Dartmouth Street also has a number of rehabilitated commercial and residential buildings. However, many visitors to the site would travel by way of Columbus Avenue or Tremont Street and would receive quite a different impression of the area. Both streets have a striking number of rundown and vacant structures. The character of the streets surrounding the site are summarized and pictorially represented on the following pages.

TYPICAL TOWHOUSE RENOVATION 


\section{Character of Immediate Area}
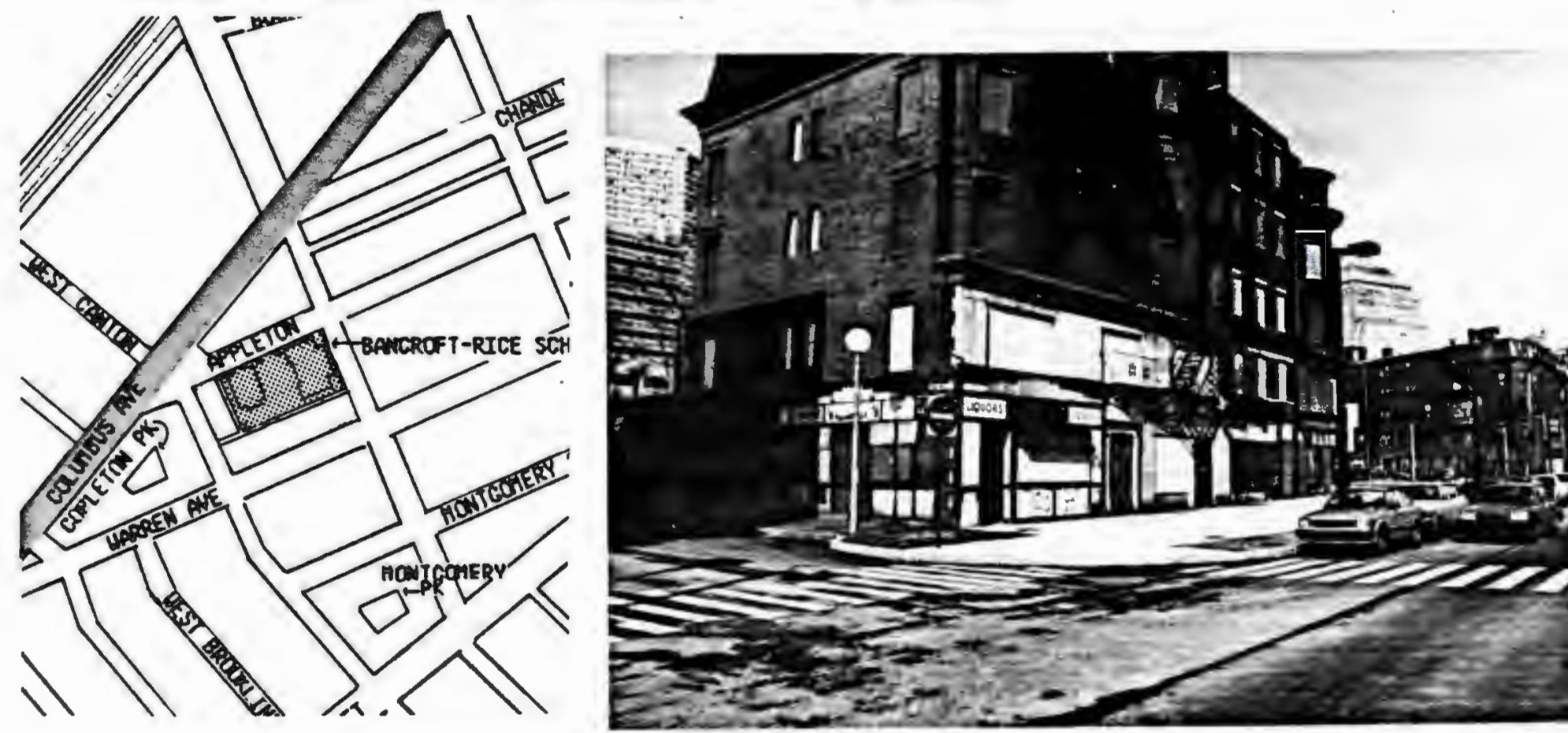

Columbus Avenue

Character: Commercial and residential, generally unattractive, poorly maintained buildings, many vacant and under-utilized structures, primarily rental housing.
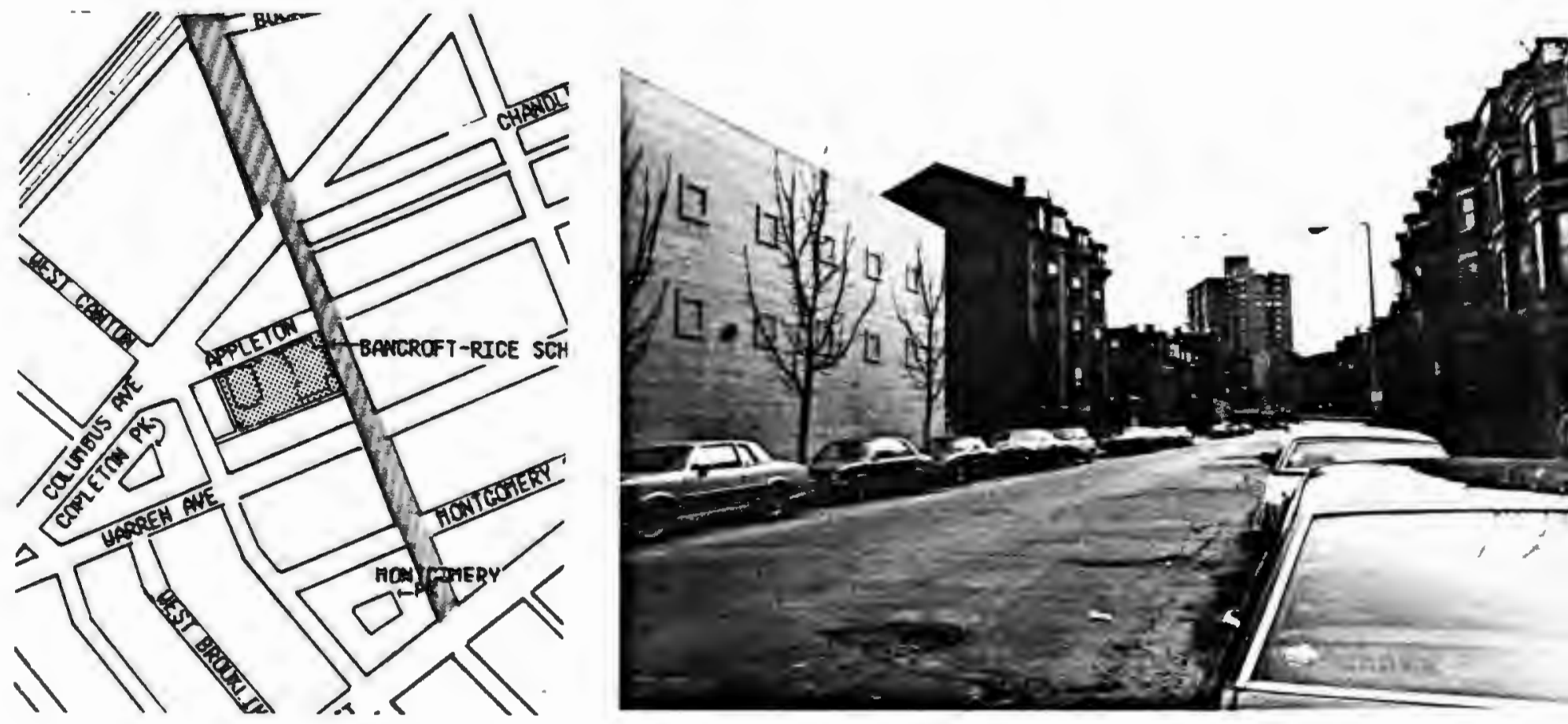

\section{Dartmouth Street}

Character: Commercial and residential, generally attractive, many renovated structures, some ouner occupled awellings 


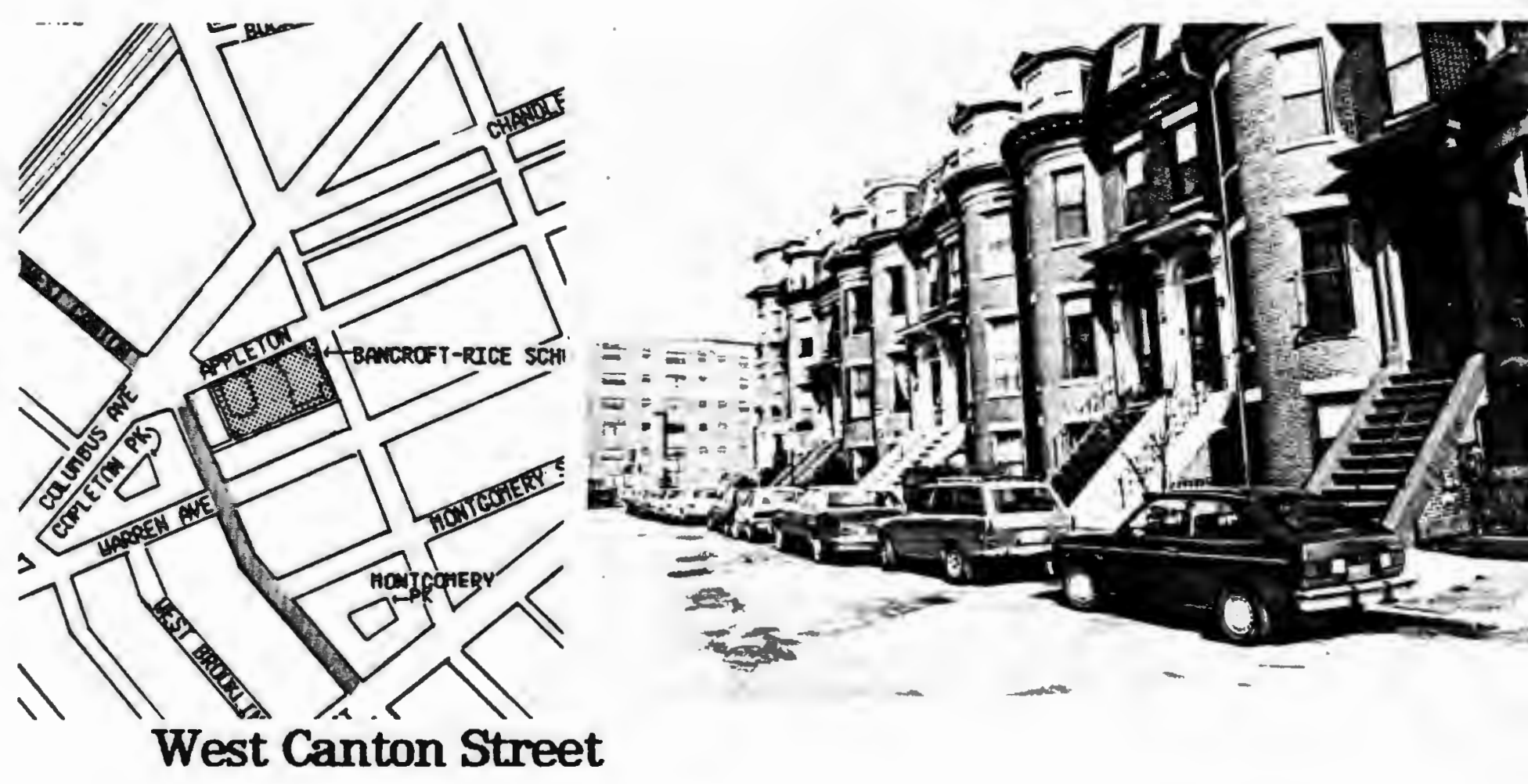

Character: Residential, attractive, primarily renovated buildings, predominantly owner occupied dwellings.
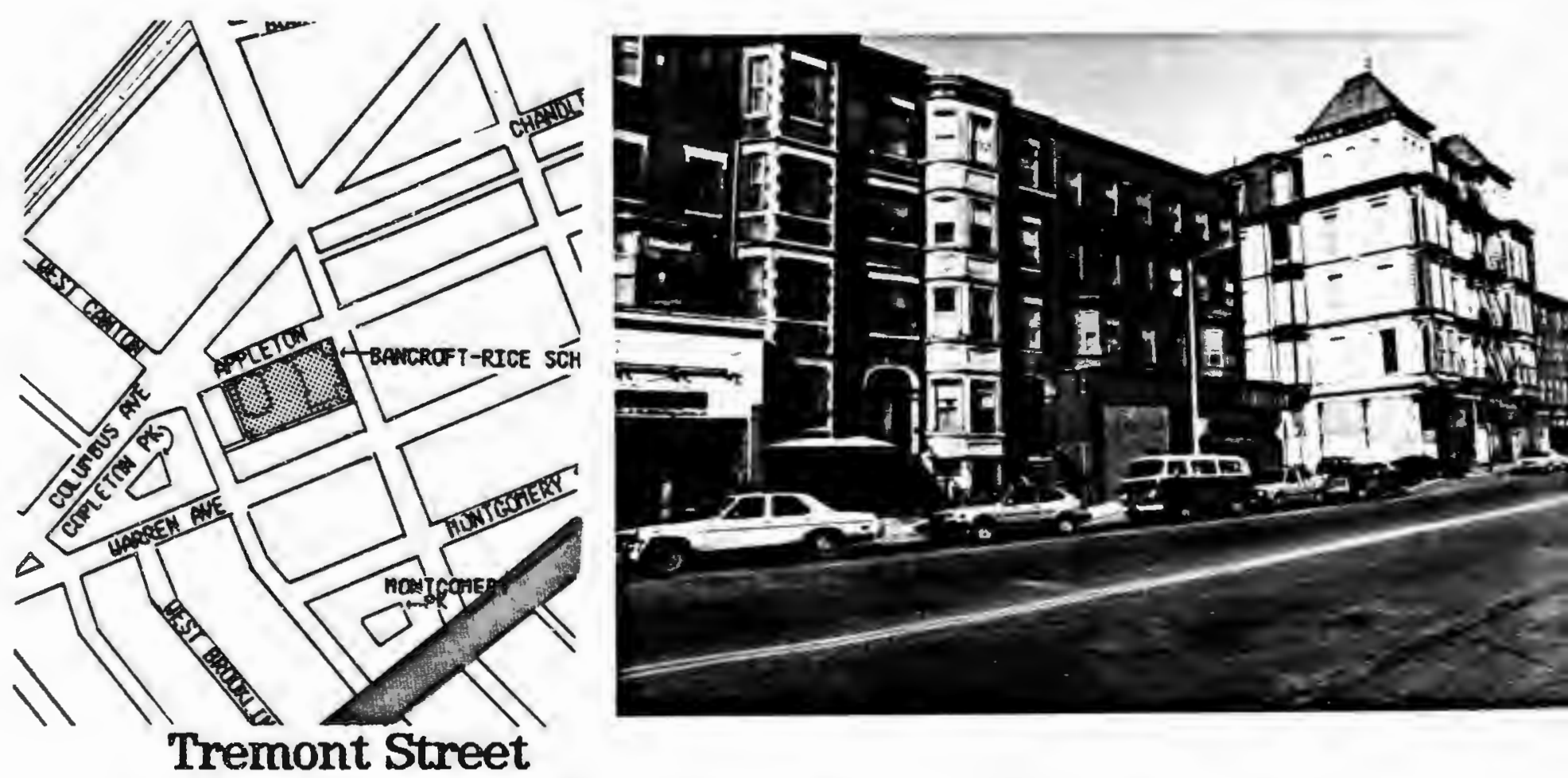

Character: commerclal and resloential, generally unattractive, many poorly maintained bulldings, many vacant and under-utilized structures, primarily rental nousing. 

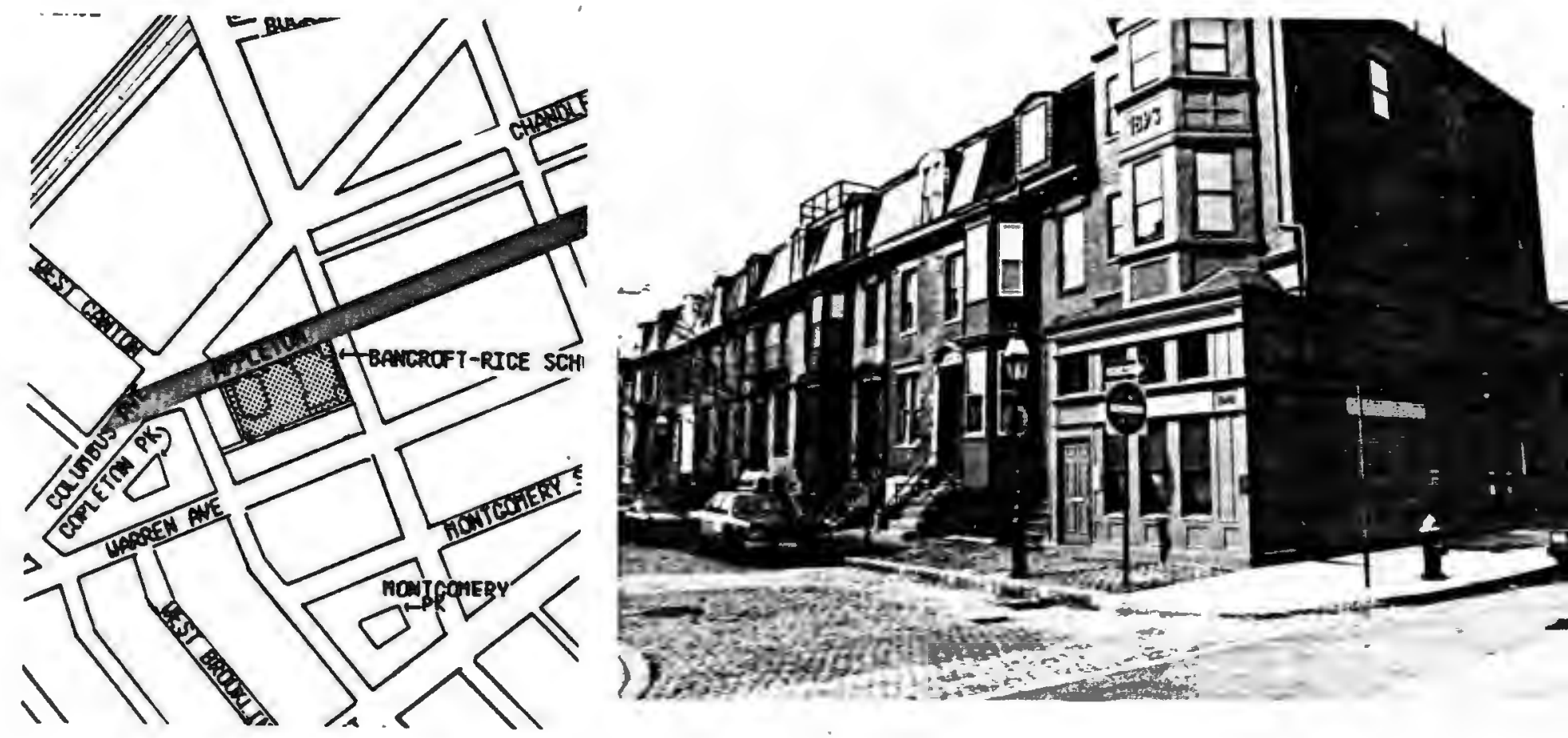

\section{Appleton Street}

Character: Residential, attractive, many renovated structures, many owner occupled dwellings.
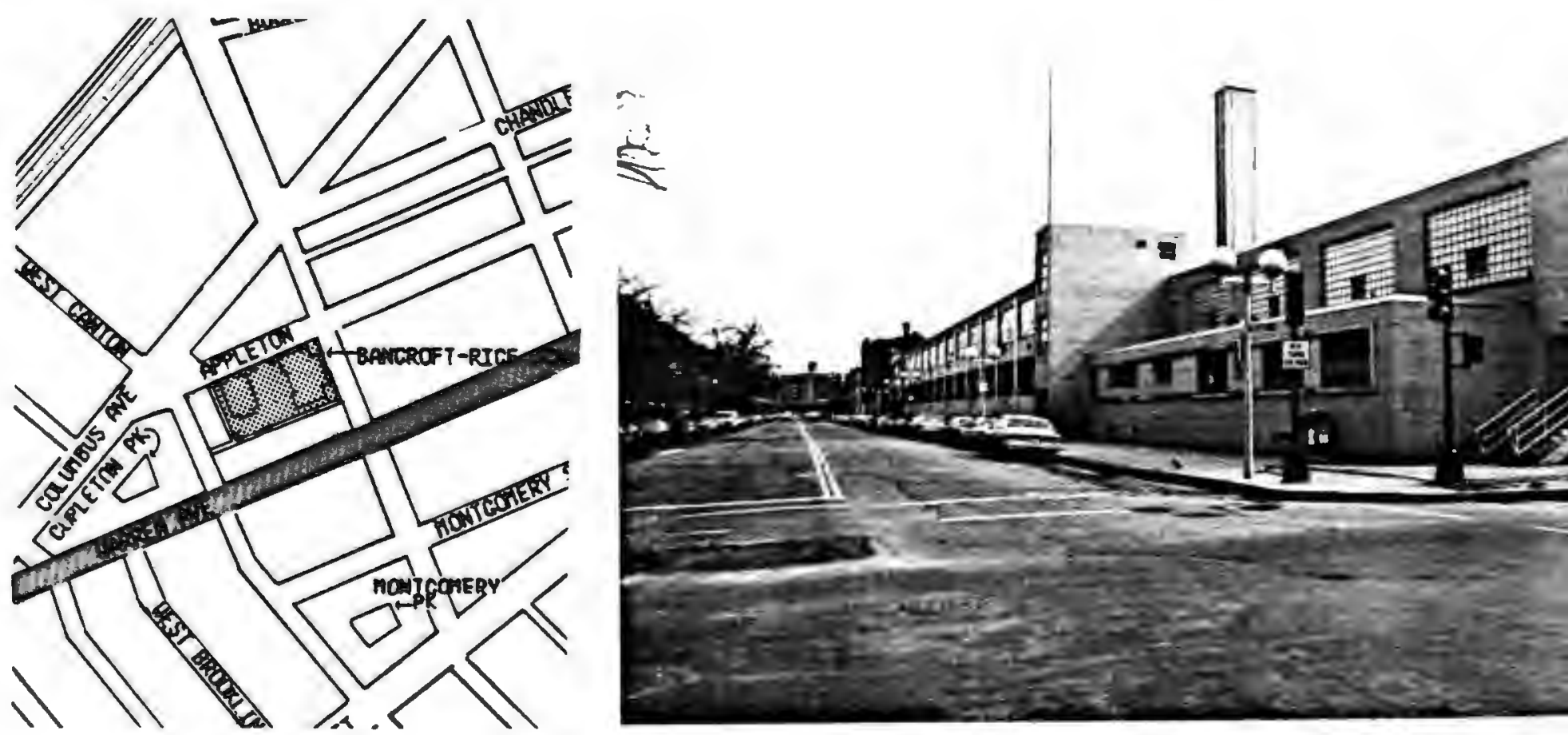

\section{Warren Avenue}

Character: Residential and institutional, some renovated structures, primarily rental housing, unattractive school bullding, charred remains of a church fire. 


\section{Transportation Linkages}

As illustrated by the following map, the site is served by many modes of transportation. Traveling by automobile, Dartmouth Street provides a direct route to Back Bay, Commonwealth Avenue (Rt. 30), and Storrow Drive (a main East-West Route). In addition, the entrance to the Mass Turnpike is less than $\frac{1}{2}$ mile from the site.

Public transportation is also readily available. Massachusetts Bay Transit Authority (MBTA) busses, both inbound and outbound, service stops within 2. blocks from the site and connect to the Greenline Subway. The completion of the Southwest Corridor, currently underway, will make public transportation even more accessible.
This project will provide an extension of the Orange Line Subway stretching from Washington Street in downtown (connecting with the Red Line) to the Forest Hills Station in Jamaica Plain (connecting with many commuter lines). The corridor will also provide a route for Amtrak high speed commuter trains expanding service between Boston and points South and West. The planned Back Bay Station offering access to the Subway and Commuter trains will be located only two blocks from the Bancroft-Rice School. In addition to the transportation advantages of the Corridor Project, a park is planned for the ground surface over the tracks from the Back Bay Station South West through the South End. The Corridor Parkland will provide new recreational facilities for residents. The project is scheduled to be completed in 1985.2

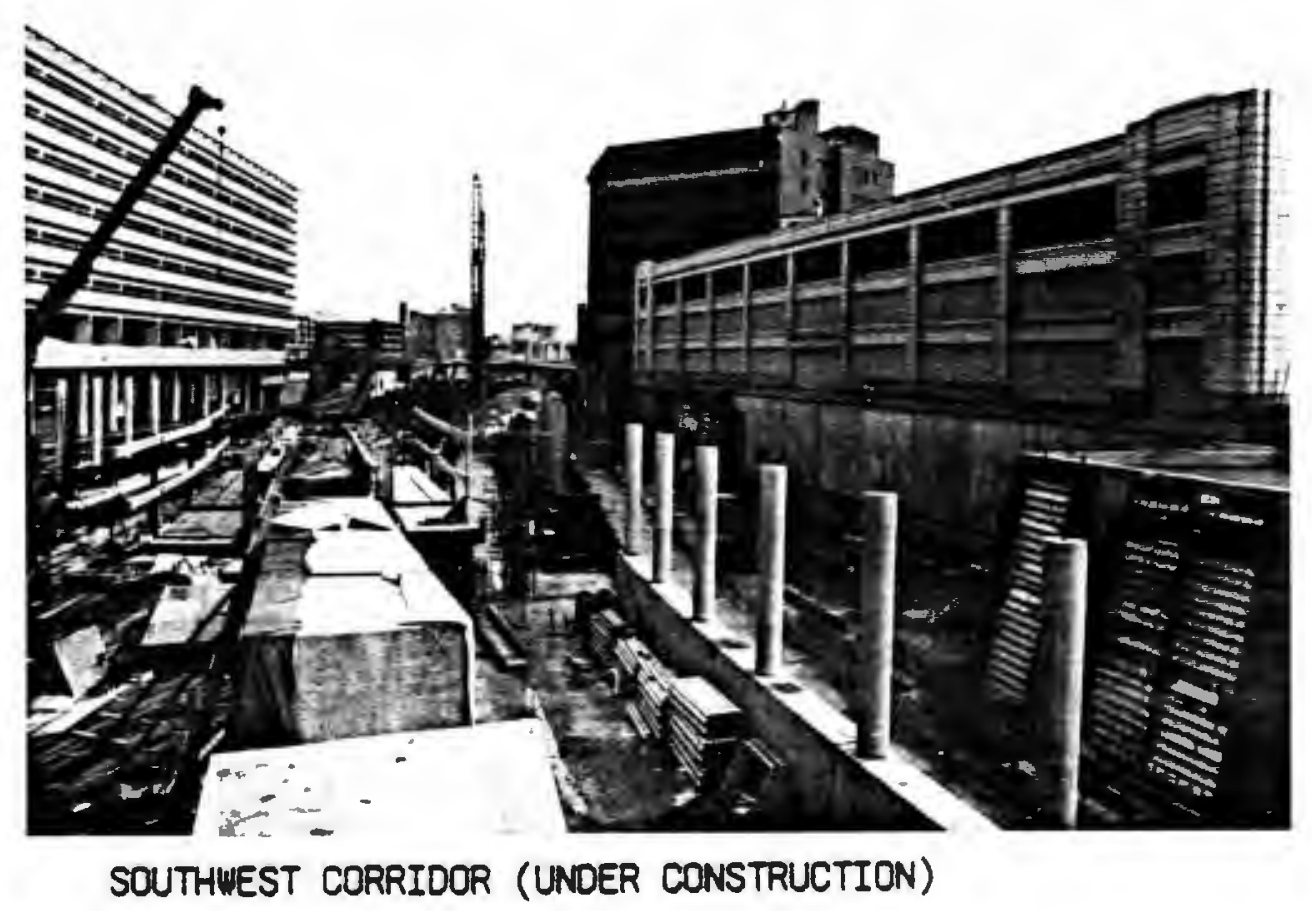




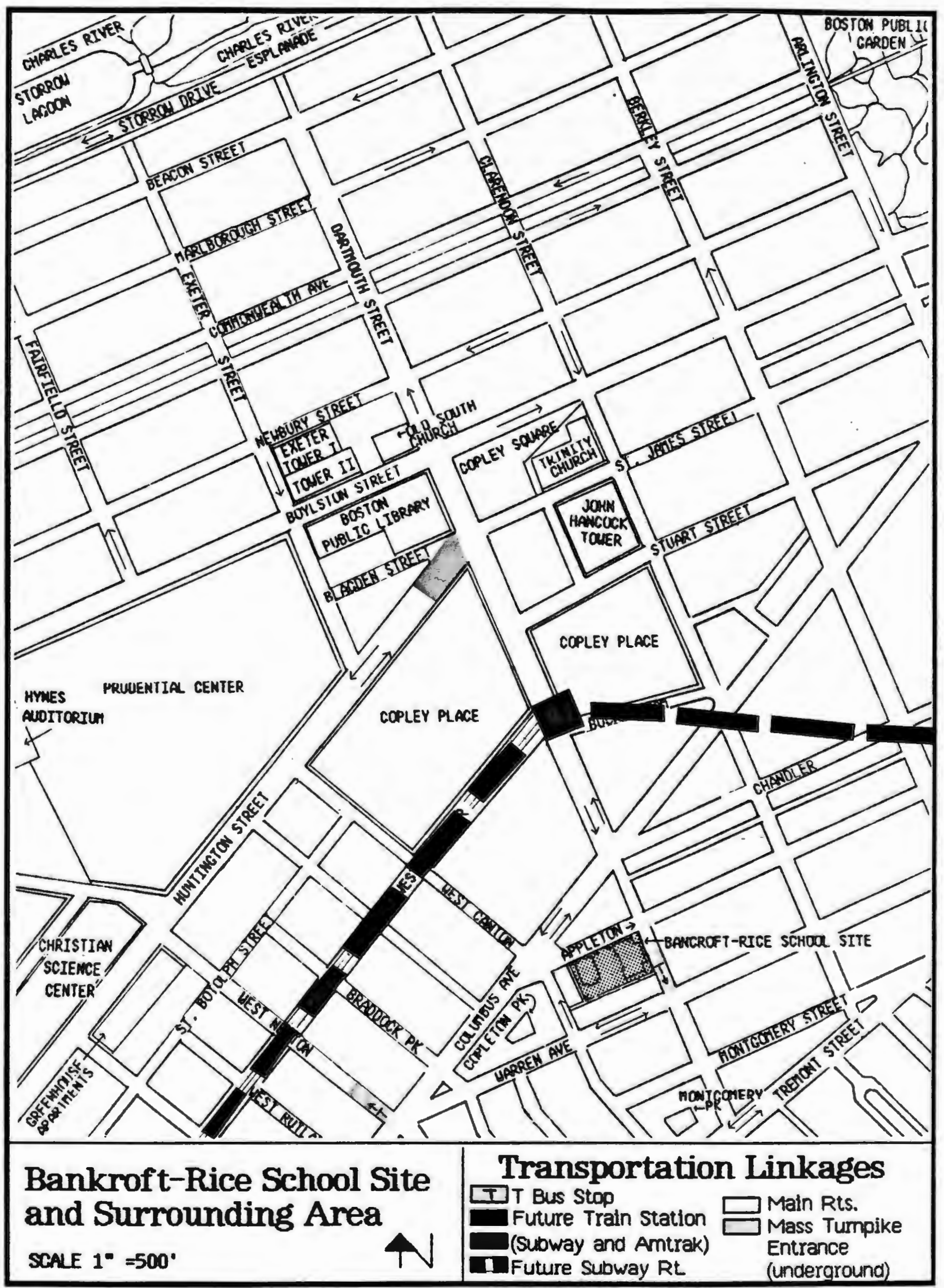




\section{Parking}

The site presently offers a generous amount of on-site parking. In addition, on-street parking is available in the surrounding area, however, the majority of spaces are restricted to South End residents and regulated by permits. A few visitor parking spaces are located on Dartmouth and West Canton Streets. Columbus Avenue and Tremont Street also provide public parking but are rather an inconvenient walk from the site. Parking availability is illustrated on the following map.

\section{Access to Services}

As indicated by the following map, the site is extremely accessible to all types of services. The area is rich in cultural and recreational activities with its many theaters, galleries and parks. Expanding present recreational facilities, the Corridor Parkland, discussed earlier, will be located only two blocks away. The Boston Public Library is also within comfortable walking distance. There is an abundance of retail establishments within close proximity to the site, ranging from the elegant bou tiques of Newbury Street to the large anchor stores at the Prudential Center and Copley Place. Food shopping needs are met by a major grocery store located at the Prudential Center and small convenience-type stores in the immediate area. In total, the location clearly offers the carfree accessibility to services that most urbanites seek.

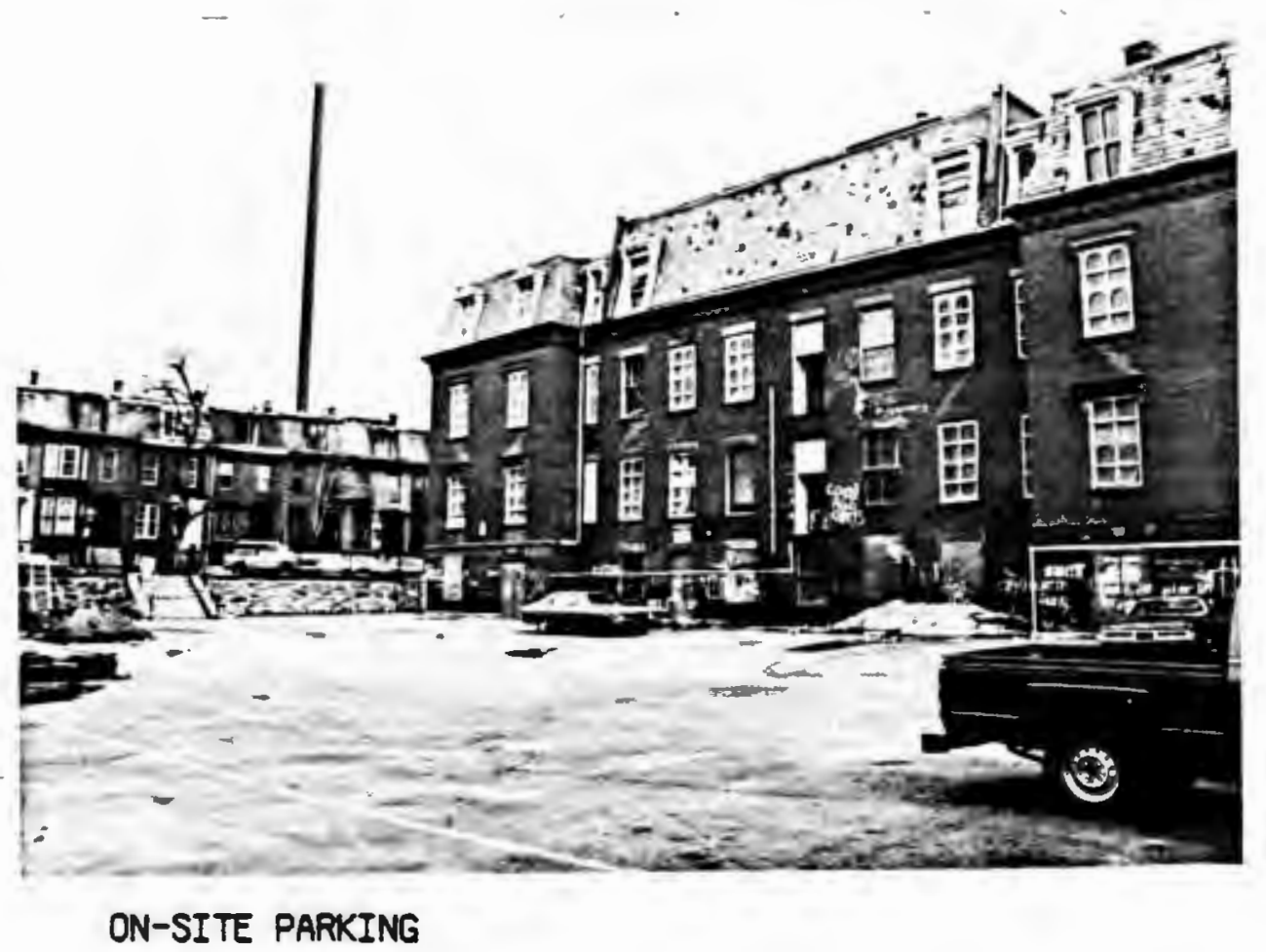




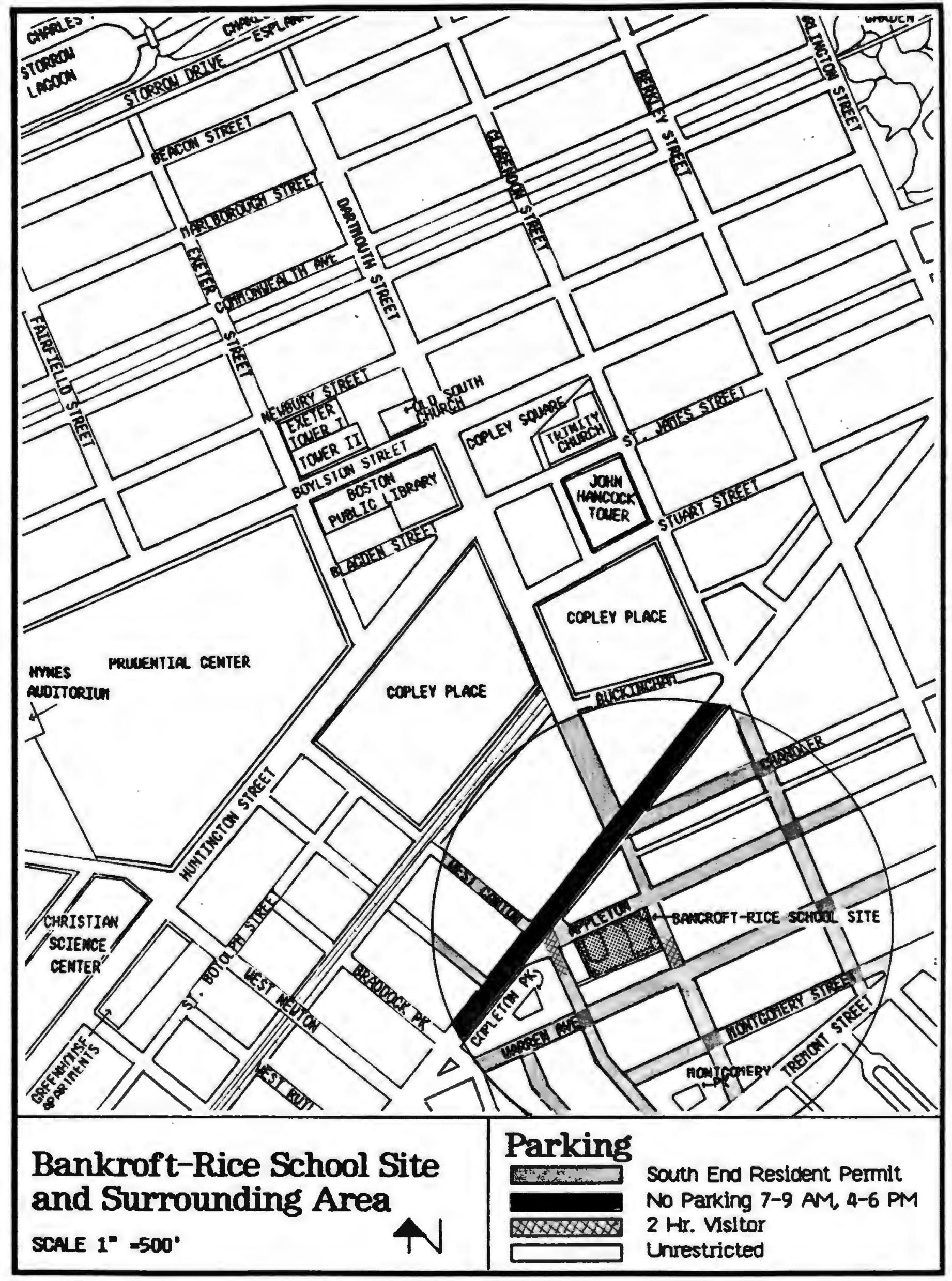




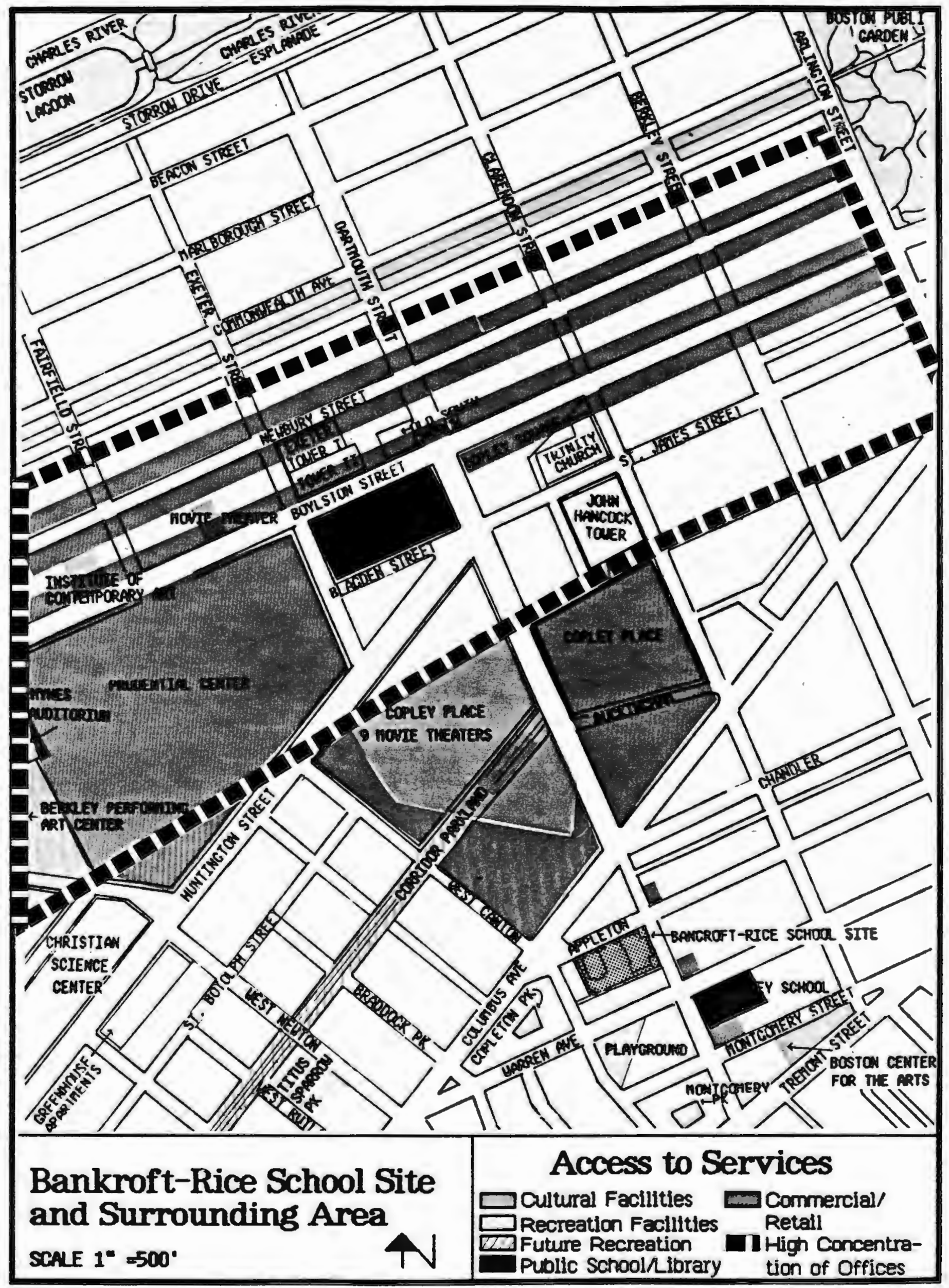




\section{Existing_Regulations ${ }^{3}$}

\section{Regulation of Uses}

The site's zoning classification is $\mathrm{H}-3$. In general, the " $\mathrm{H}$ " indicates that the District is intended for primarily residential use. All types of attached, detached and semi-detached single family, two family, and multi family dwellings are allowed. All commercial and industrial uses are prohibited. However, service establishments such as barber shops, dining rooms, and news stands are permitted as accessory uses to buildings with 50 dwelling units or more, as long as they are entered from within the building and geared primarily to serve the occupants of the site. Offices of an accountant, architect, attomey, dentist, physician or other person not accessory to a main use may be located in an $\mathrm{H}$ District as a conditional use. This requires the property owner to apply for a Conditional Use Permit from the Board of Appeal which will then make a determination on the case after public notice and hearing. Appendix A provides a complete list of uses permitted by right as well as conditional uses allowed within the $\mathrm{H}$ Districts.

\section{Dimensional Regulations}

The " 3 " in the site's H-3 zoning classification is indicative of a floor ratio requirement. This means that the floor area of a structure can be no greater than three times the total lot size. This is only one of the dimensional requirements imposed on the Bancroft-Rice property. Appendix B summarizes the dimensional regulations, interprets what they mean in terms of the site and examines the current status of compliance or non-compliance with the regulations.

\section{Parking Requirements}

All parking spaces provided onsite must have minimum dimensions of at least $8 \frac{1}{2}$ feet by 20 feet. The number of parking spaces required is dependent on the type of use:

$\begin{array}{ll}\text { Use } & \text { Requirement } \\ \text { Residential } & \text {.6 space per dwel- } \\ \text { ling unit } \\ \text { Office } & 1 \text { space per } 900 \mathrm{sq} . \\ & \mathrm{ft.} \text { of ground floor } \\ & \text { area and/space per } \\ & 1,800 \mathrm{sq} \text {. ft. of } \\ & \text { other floor area } \\ & 1 \text { space per } 1,800 \\ \text { Institutional } & \text { sq. ft. of floor } \\ & \text { area }\end{array}$

\section{Points of Interest}

\author{
Specific points of interest ex- \\ isting in the area surrounding the \\ Bancroft-Rice School Site are describ- \\ ed and pictorially represented in \\ Appendix C. The purpose of this \\ display is to familiarize the reader \\ with the many attractions of the \\ neighborhood which may entice poten- \\ tial users to the site. These amen- \\ ities increase the desirability of \\ the site location and consequently \\ also increase the potential market \\ price once redeveloped. The Copley \\ Place Development, designated as a \\ point of interest is discussed in de- \\ tail later in the chapter.
}




\section{Summary of Indirect Economic Influences}

The examination of indirect economic influences indicates the site's propensity for residential uses. To begin with, the immediate neighborhood is primarily a residential quarter, where considerable redevelopment is occurring. It's location offers many attractions for residents. The most important one being the proximity to the fashionable Back Bay District, where every desirable commercial, cultural and recreational service is available. The site is also easily accessible to many transportation modes, including a new subway line which will link the area with all commuter trains. The parking requirements of a residential use could be accomodated on the site. In addition, resident parking is available on most of the surrounding streets.

The existing zoning regulations also encourage residential development. All types of housing is permitted in the district, while industrial and al most all commercial uses are prohibited. Specific types of professional offices such as those of a physician, architect, or accountant are allowed as a "conditional use". However, this type of use is less established in the area. There may be a potential market for offices in the area but currently this remains relatively untested.

After initial review of the neighborhood, the permitted use which appears most viable is residential. A small number of offices may be considered as part of a mixed use development, but the most appropriate use is residential. No prohibited use appears attractive enough to con- template the likelihood of a zoning change or variance.

In addition, many historical, cultural, architectural, and recreational points of interest are located within close proximity to the site. They seem to attract residents who wish to live near them. Their notariaty also helps to advertise and spotlight the neighborhood. All the preceeding factors add to the marketability of a residential development at the Bancroft-Riee site. 


\title{
B. Direct Economic Influences
}

\author{
While indirect economic influ- \\ ences tend to limit viable development \\ opportunities to some type of residen- \\ tial units, the analysis of factors \\ directly affecting supply and demand \\ further specifies the highest and best \\ use for the property. The influences \\ are investigated under the following \\ topics : \\ Description of Market Area Population, \\ general background information on con- \\ sumers in the market area and identi- \\ fication of the target population, \\ Market Conditions, interpretation of \\ present trends and other information \\ regarding current conditions, \\ Recent Development, examination of all \\ types of new development, with partic- \\ ular attention given to residential \\ projects, \\ Projected Housing Demand, estimation \\ of future residential demand,
}

\section{AND}

Competing Housing Projects, identification of current and expected future housing development.

The chapter concludes with a summary of market analysis findings and an indication of parameters for optimum development of the site. 


\section{Description of Market}

\section{Area Population}

The South End is a dichotomous neighborhood in transition. It can be viewed as two distinct geographic areas of diverse character as described in the previous "Location" section. In turn, its population can be viewed as two groups with dramatically different traits corresponding closely to the two geographic areas.

The first group is more establish ed in the area and is generally situated in the Southern-most section of the South End. It is composed primarily of low to moderate income residents, the majority of whom are either black, hispanic or oriental. This group inherited the South End over the years as the neighborhood declined and the middle to upper income residents moved to outlying areas.
The second group is a recent addition to the area's population. They began appearing in the late 70 's and located primarily in the Northern section of the South End. The attraction for this in-migration was and still is the proximity to points of interest, readily available services and access to transportation modes linking the area with major work centers. The new group of residents is predominantly white young professionals, generally single or newly married couples without children. They are often employed in the nearby office centers of Back Bay and the Financial District. This inward migratory segment of the neighborhood population, with its demonstrated preference for the Back Bay fringe area, and relatively high income, comprises the obvious target for any proposed residential development.

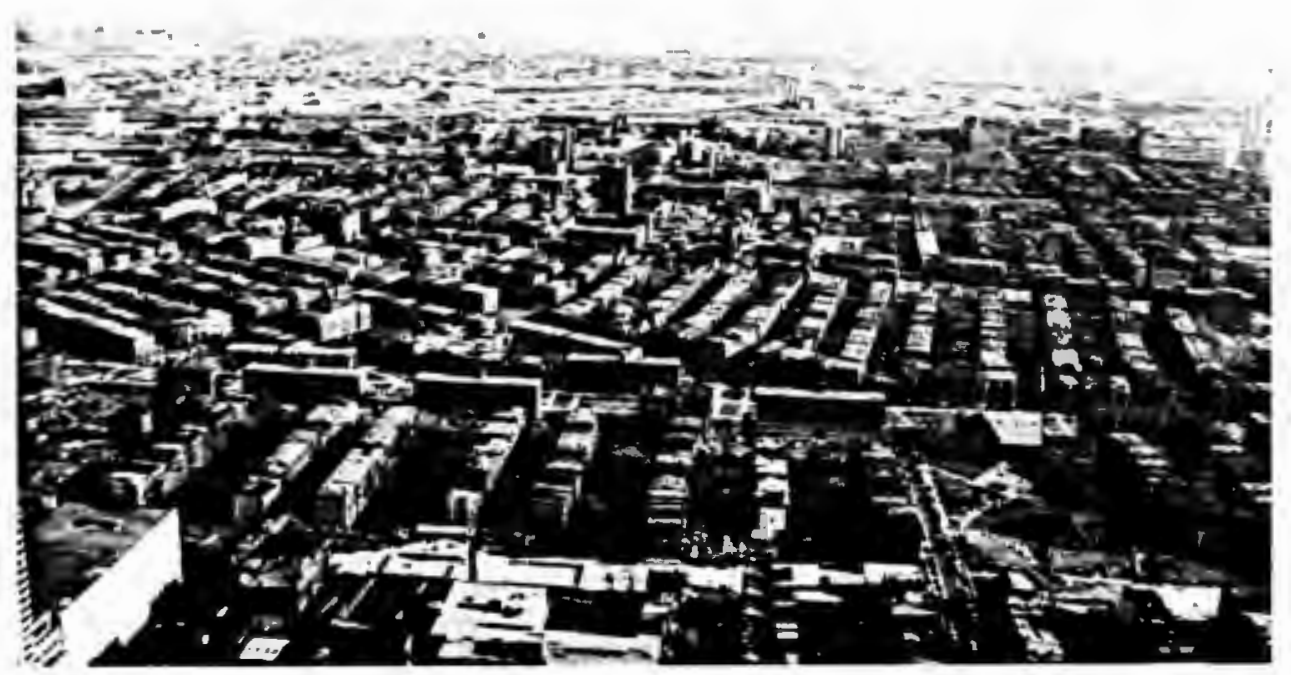

OVERVIEN OF THE SOUTH END 


\section{Market Conditions}

The influx of this new-type resident group is expected to continue, increasing the demand for higher quality housing accordingly. To substantiate this assumption as well as the existence of generally perceived characteristics of the new population, current trends are analyzed and interpreted. For reader-ease, the information is organized by general interpretive claims which are supported by the available data. Census information is examined at three levels: the census tract (encompassing the site and comprising a portion of the Back Bay fringe area), the City of Boston (showing City wide trends), and the SMSA (indicating activity in the entire metropolitan area).

Appendix D illustrates the location of the number 707 Census Tract, which encompasses the site.
1. THE POPULATION OF THE IMMEDIATE

AREA SURROUNOING THE SITE IS IN-

\section{CREASING.}

While the population of the SMSA and the City has remained relatively constant over the last two decades, the census tract has experienced an $8 \%$ increase. The area had seen a decline in population through the 1960's but began enjoying a renewed popularity after 1970 .

\section{Population Change}

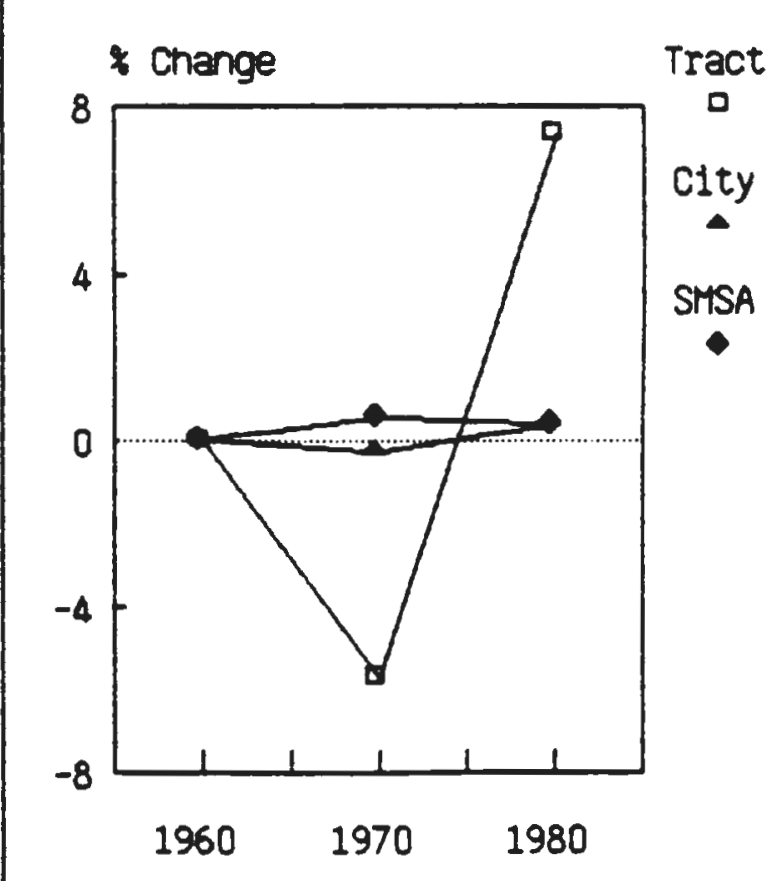

- U.S. Consus of Pop. and Housing 1960,70,6 80 
2. THE INCREASE IN POPULATION IS

PRIMARILY DUE TO THE IN-MIGRATION

OF YOUNG, SINGLE OR NEYLY MARRIED

INOIVIDUALS MOSTLY UITHOUT CHILDREN,

AND UHOM DEMONSTRATE THE DESIRE AND

ABILITY TO PAY FOR RELATIVELY HIGH

\section{QUALITY HOUSING.}

This claim is broken down into

the following three main components:

\section{YOUNG}

The percentage of the population ages 25-34 was distributed relatively evenly over the tract, city, and SMSA in 1960. However, between 1970 and 1980 , the portion of total population in the tract comprised by this group rose sharply. As of the last decennial census, approximately a third of all the people living in the area surrouding the sites are between the ages of 25 and 34 .

\section{Percent Population}

\section{Ages 25-34}

Tract

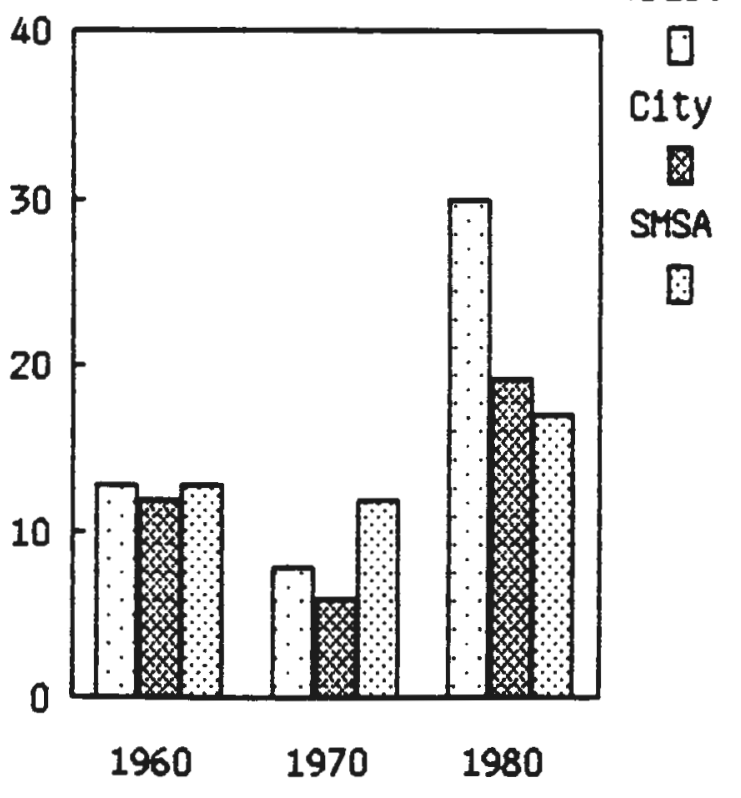

U.S. Census of Pop. and Housing 1960,70,8 80 
SINGLE OR MEYLY MARRIED, MOSTLY

\section{IITHOUT CHILDREN}

The majority of the new population appears to be either single or childless couples. The median persons per household in the tract has decreased from 1.9 in 1970 to 1.59 in 1980. This is considerably less than the median household size found in the City or SMSA. This difference supports the notion that the immediate area is an urban neighborhood whose population turns over as its pre-family couples move to the suburbs when they decide to have children and new singles and couples seeking the amenities of urban life move in.

\section{Median Persons}

\section{per Housing Unit}

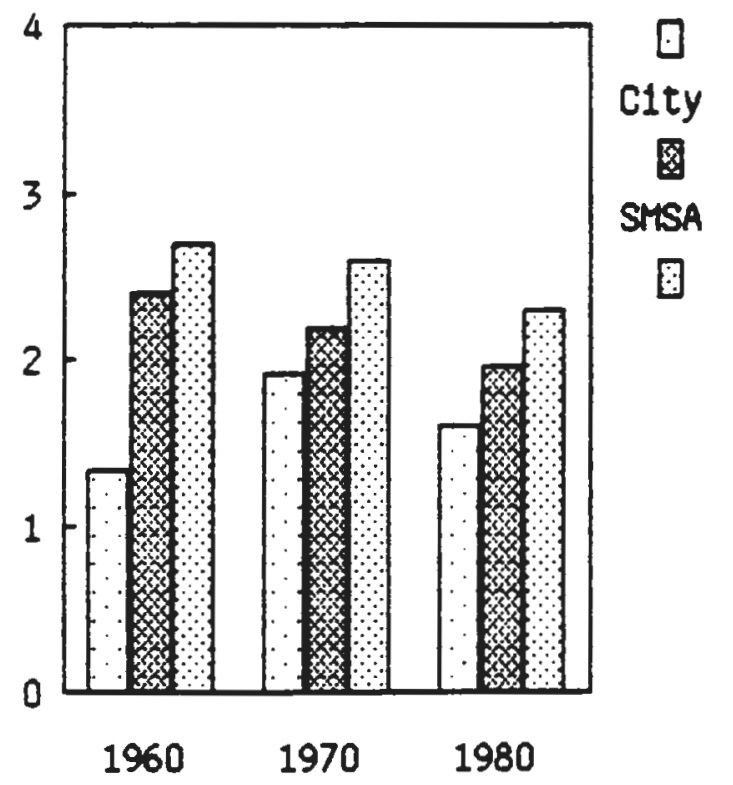

DESIRE AND ABILITY TO PAY FOR RELATIUELY HIGH OUALITY HOUSING

The percent of population in the neighborhood able to purchase relatively high quality housing has tripled since 1960. In 1980, one out of five households could afford a home valued at $\$ 65,000$ or more. This compares with one out of seven households in the City and one out of four households in the SMSA. It is also important to note that these percentages have been decreasing in the City and SMSA while the census tract has experienced a steady increase. This information demonstrates that the area is attracting households with higher incomes and gentrification is occurring.

In the rental market, $39 \%$ of the census tract could afford $\$ 500$ or more in 1980 compared to only $20 \%$ in the City and $31 \%$ in the SMSA. In other words, in 1980, there was a greater percentage of households earning $\$ 20,000$ or more than in either the City or SMSA. 


\section{Income}

\section{Ability to Afford High Quality Housing -..}

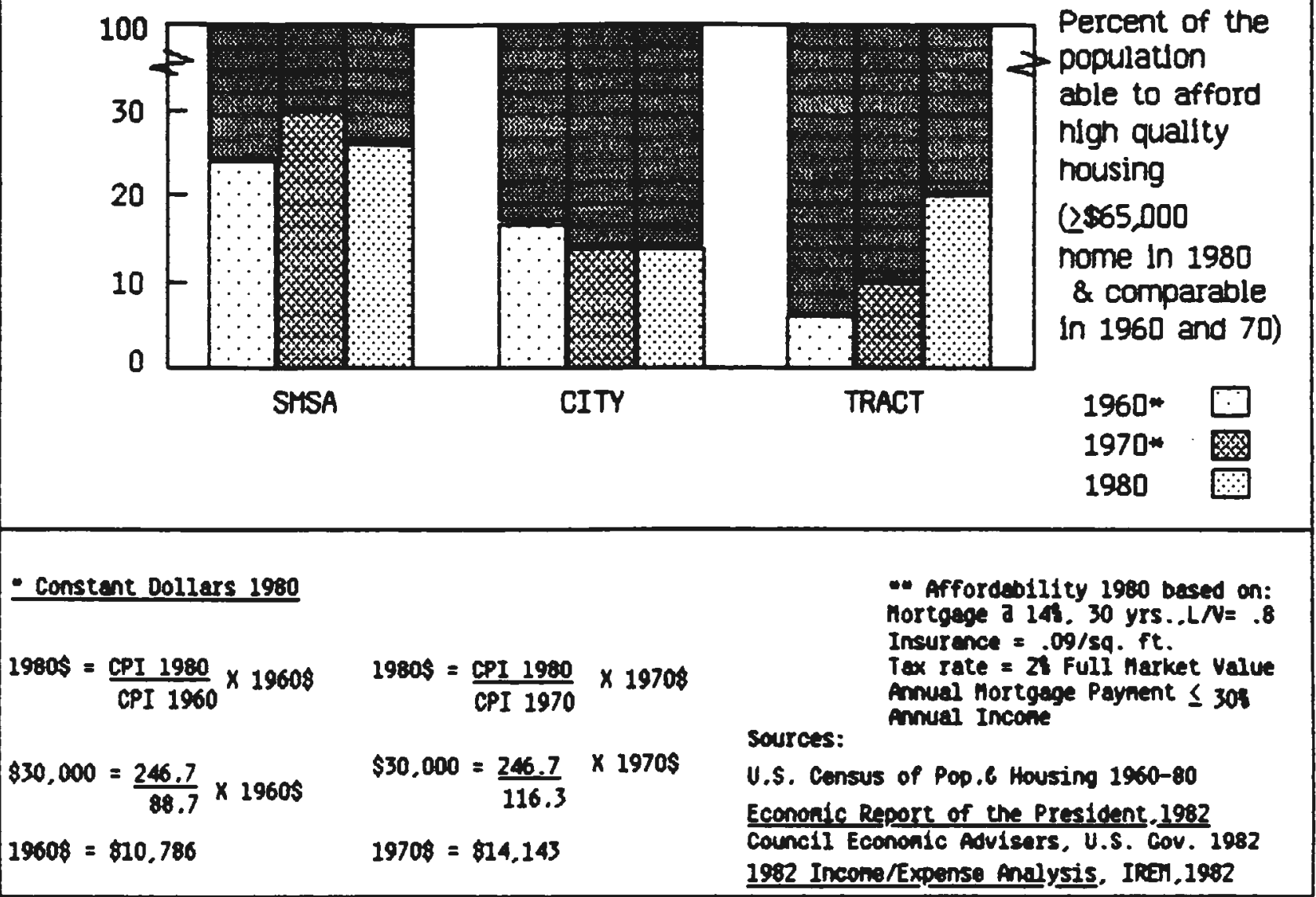


The examination of property values and contract rents also support the claim that the new neighborhood population is able to afford comparably high quality housing. In 1960 the census tract exhibits a relatively low median home value and rent level. However, by 1980, due to the influx of the new resident group, rents and home values in the tract had surpass ed both the City and SMSA. The relatively high median housing prices, in light of the declining vacancy rates indicates a greater demand for housing and a preference for high quality residences.
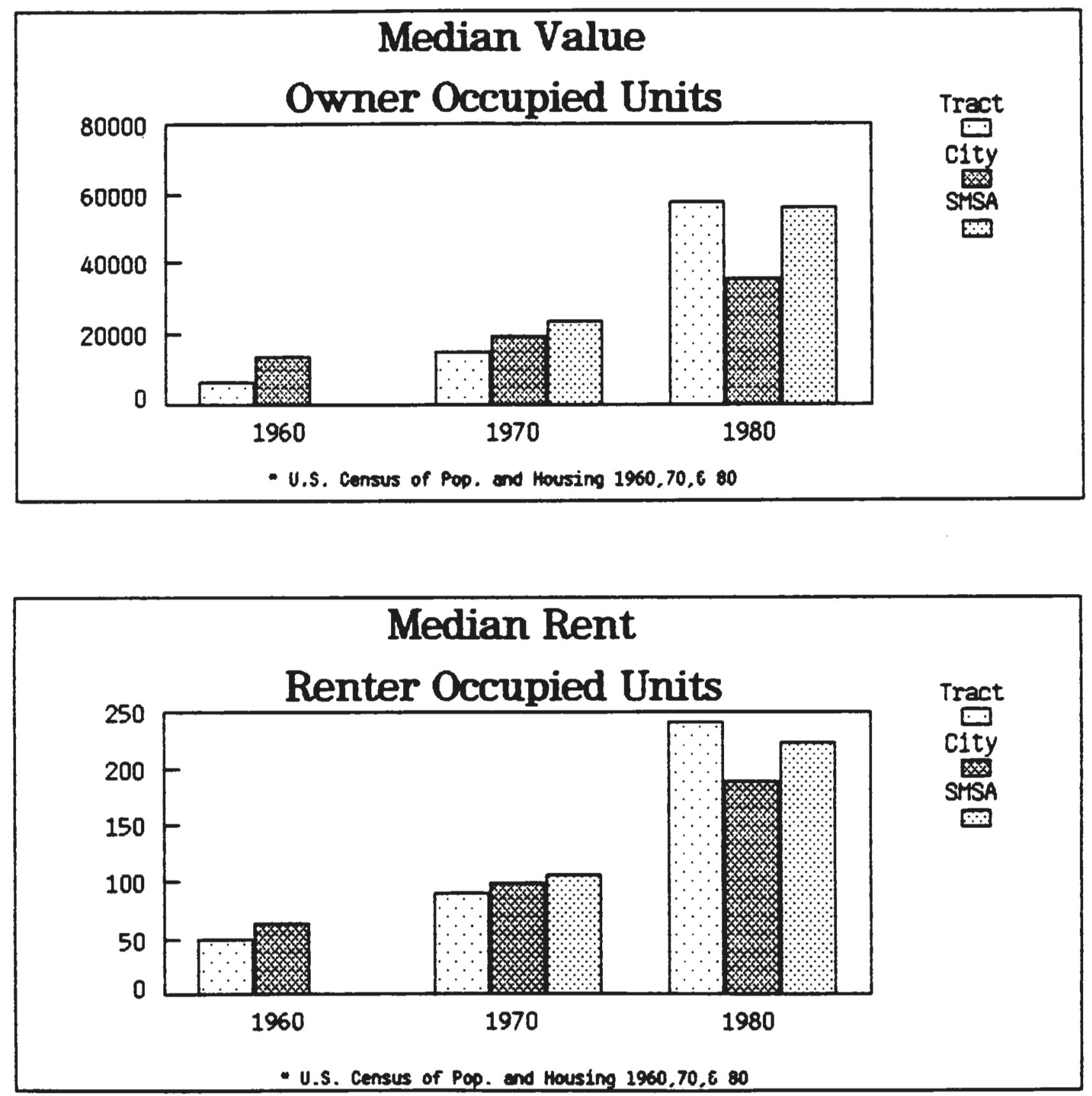
3. IN RESPONSE TO THE GROUTH IN POPULATIOH, HOUSING CONSTRUCTION IS

\section{INCREASING.}

The neighborhood's renewed popularity has increased demand and caused a sharp incline in residential construction since 1970. This is compared to a decrease in construction in both the City and SMSA. This new construction is generally in the form of renovation of existing structures. New housing units are created within old buildings. The majority of new units are specifically geared to the characteristics of the new population group.

\section{Housing Construction}

\section{CENSUS TRACT}

Units

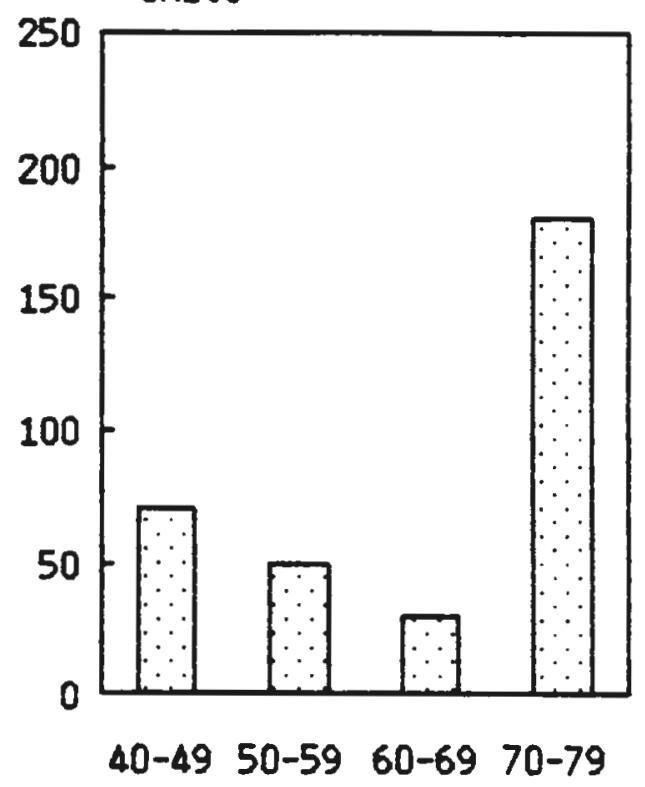

- U.S. Census of POp. and Housing 1960,70,680

\section{Housing Construction}

\section{Housing Construction}

\section{GITY}

\#Un1ts

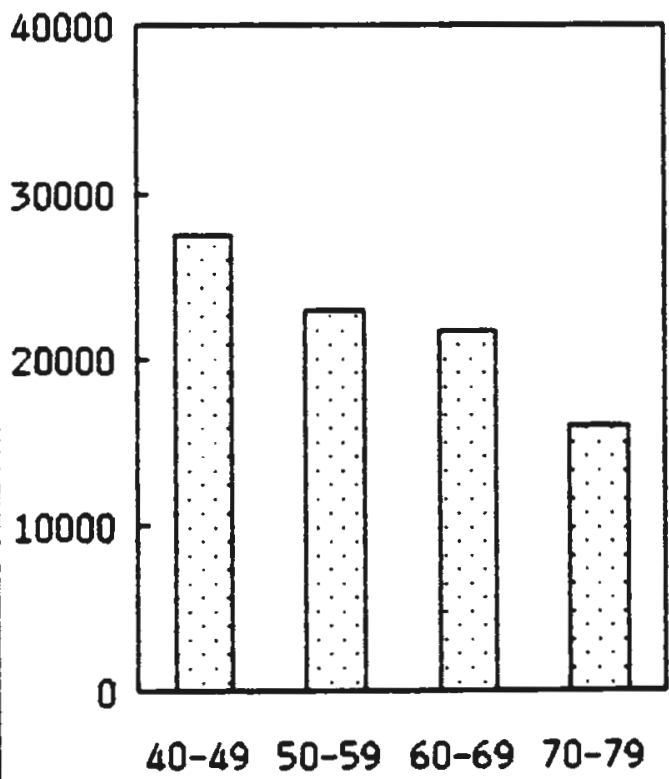

- U.S. Census of Pop. And Housing 1960,70,6 80

\section{StisA}

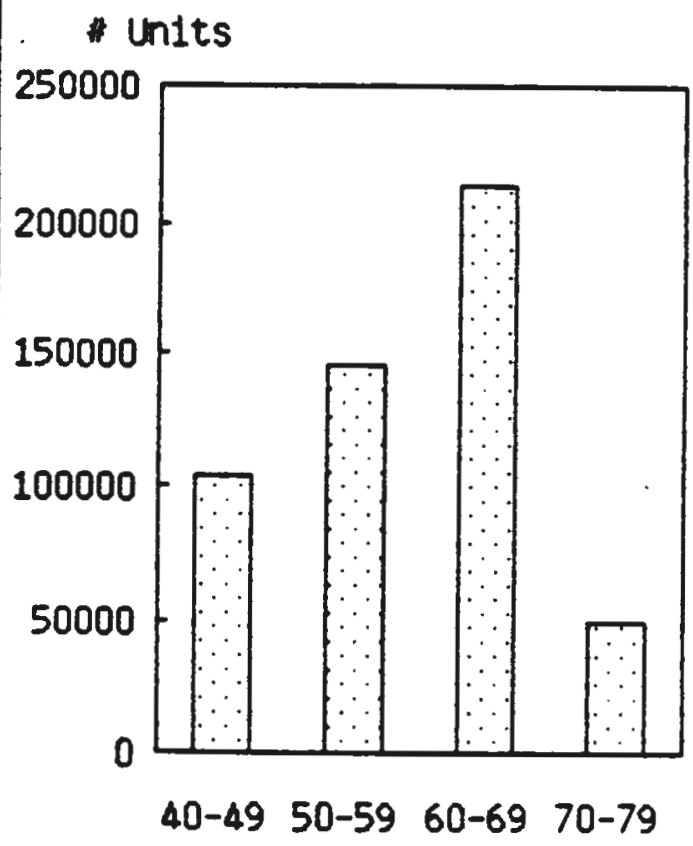

- U.S. Consus of Pop. and Housing 1960,70,6 80 
4. THE VACAMCY RATE IN THE

\section{IMMEDIATE AREA IS DECLINING.}

The decreasing vacancy rate of the census tract contrasts sharply with the increasing rate existing in the City. This trend parallels the expanding population. However, the vacancy rate still appears somewhat high. A partial explanation for the high rate 1 ies in the type and condition of existing units. Many vacant units are in poor condition and exist in deteriorated buildings. In addition, many units lack the amenities which seem to attract the new resident population.

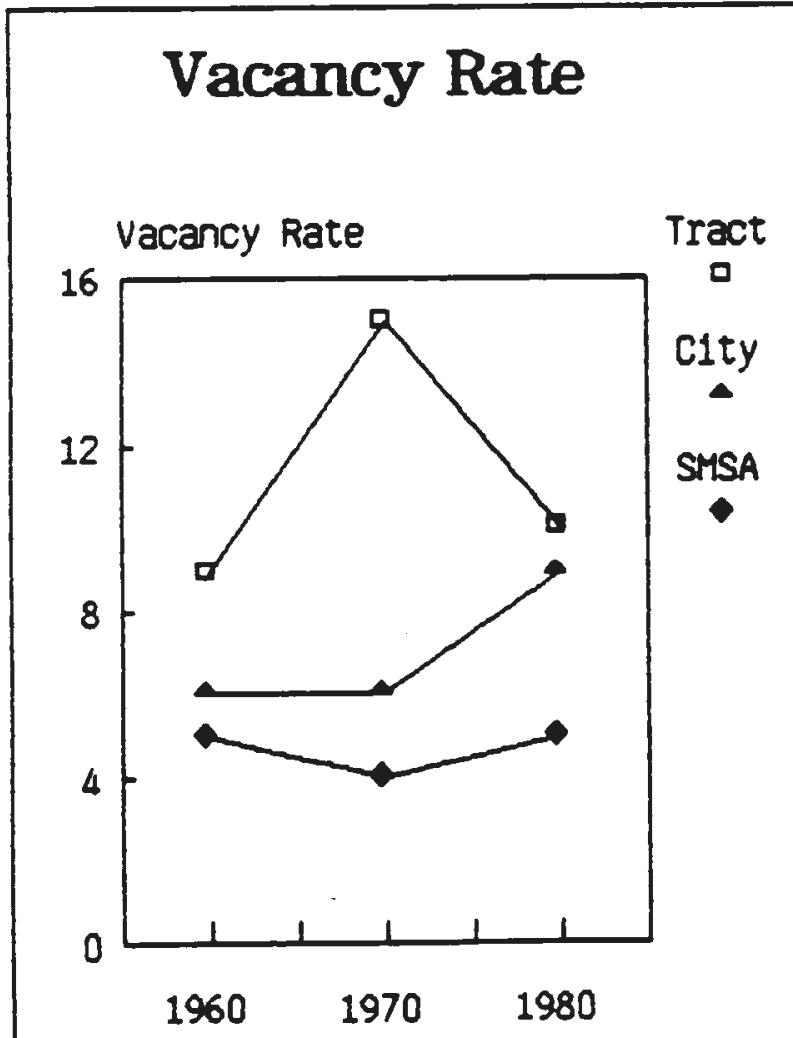

- U.S. Census of POD. and Housing 1960,70,8 80
5. THE HIGH DEMAND FOR HOUSING IN THE BACK BAY DISTRICT HAS CREATED A SPILLOVER EFFECT IN THE ADJACENT SOUTH END FRIMGE AREA, HHICH IS

\section{EXPECTED TO CONTINUE.}

From the onset, the in-migration of middle-upper income residents into the South End has been closely related to the redevelopment activity in Back Bay. As Back Bay re-emerged as a prime prestigous residential quarter with its abundance of attractive amenities, housing in the area became more and more scarce and less and less affordable. The available rental housing is very limited and may only be obtained by procurring the services of a realtor generally charging a minimum of one month's rent. The high demand and relatively short supply has also significantly elevated selling prices. New condominium units range primarily from $\$ 90,000$. to $\$ 140,000$. for one bedroom and approximately $\$ 120,000$. to $\$ 250,000$ for two bedrooms. The logical spillover area for potential residents desiring the amenities of Back Bay, but unable to pay the high price, is the South End. The South End is also particularly attractive to residents who need to purchase property for tax benefits. Back Bay residents find they can purchase a home for close to the same monthly payments as they pay for rent in Back Bay. 
The five following claims result

from an informal survey of the area

realtors and developers. ${ }^{4}$ These statements are also compatible with the interpreted census data.

6. THE TYPICAL CONDOMINIUH PURCHASER

IN THE AREA IS A FIRST TIHE HOMEBUYER CURRENTLY RENTING AN APARTHENT AND MOST LIKELY PRICED OUT OF THE BACK BAY AND BEACON HILL NEIGHBORHOODS. THE PURCHASE OFTEN INVOLVES A TUO INCOME, CHILDLESS COUPLE. THEY ARE USUALLY PAYING RENT CLOSE TO \$700 OR MORE AND DESIRE THE TAX BENEFITS OF HOME OUNERSHIP. COMMONLY THE POTENTIAL BUYERS HAVE SIZEABLE INCOMES BUT LIMITED SAUINGS FOR A DOUN PAYMENT.

10. NEY CONDOMINIUM UNITS APPROPRIATELY PRICED AND ACCESSORIZED SELL QUICKLY. THE AVERAGE TIME ON THE MARKET IS TUO MONTHS.

7. CONDOMINIUM PRICES IN THIS

SECTION OF THE SOUTH END RANGE FROM $\$ 50.000$ TO \$140.000. THE UNITS

UNDER \$70,000 ARE MOSTLY CONVERED APARTMENTS UITH ONLY COSHETIC IHPROVERENTS. THE UNITS VELL OVER \$100,000 ARE LUXURY UNITS, PERHAPS TOO LUXURIOUS FOR THE AREA, AND HAVE NOT SOLD YELL. THE MAJORITY JF DEMAND APPEARS TO BE FOR UNITS FROM $\$ 70,000$ TO $\$ 100,000$.

8. THE MOST MARKETABLE UNITS ARE LOCATED IN THE FRINGE AREA ADJACENT TO BACK BAY.

9. POPULAR AMENITIES FEATURES ARE: PATIOS OR DECKS, RESTORED FACADES.- 


\section{Recent Development}

\section{Residential Development}

\section{(immediate area)}

It is evident that the most common new housing units in the area are condominiums created as a result of renovation of existing structures. A sample of recent condominium sales reveals that the most popular new units are approximately $950 \mathrm{sq} . \mathrm{ft}$. in size and are priced around $\$ 100,000$ Prices appear highly correlated to size and there is only a small amount of deviation from the medians. The number of bedrooms is also a deterninant of price. The median cost for one bedroom is $\$ 62,750$. and $\$ 103,000$. for the two bedrooms. The two bedroom units are much more popular than those with one bedroom, and three bedroom units are rare. Popular amenities include decks or patios, fireplaces, hardwood floors, restored facades and parking.

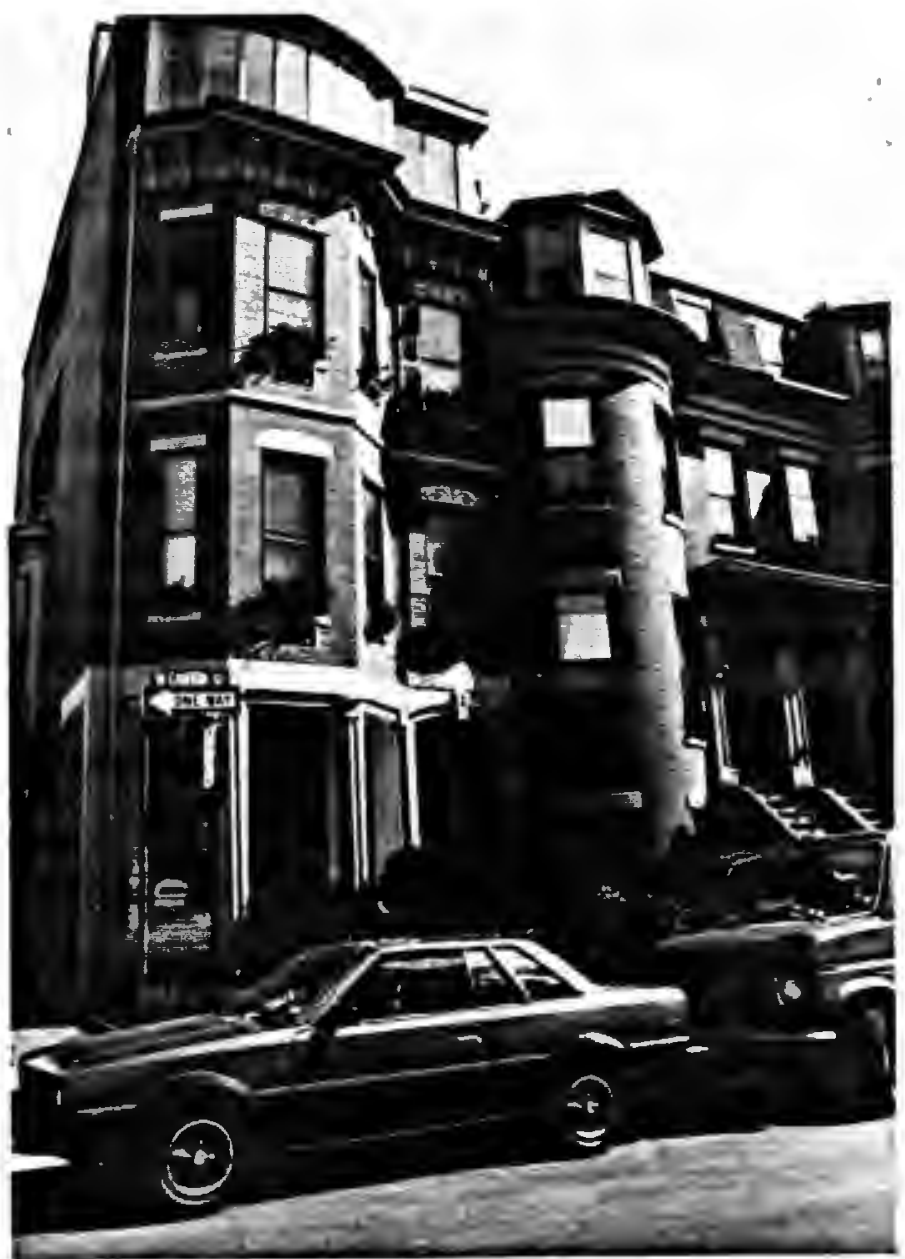

APPLETON STREET

1 BR $\$ 53,500$

2 BR $\$ 125,000$

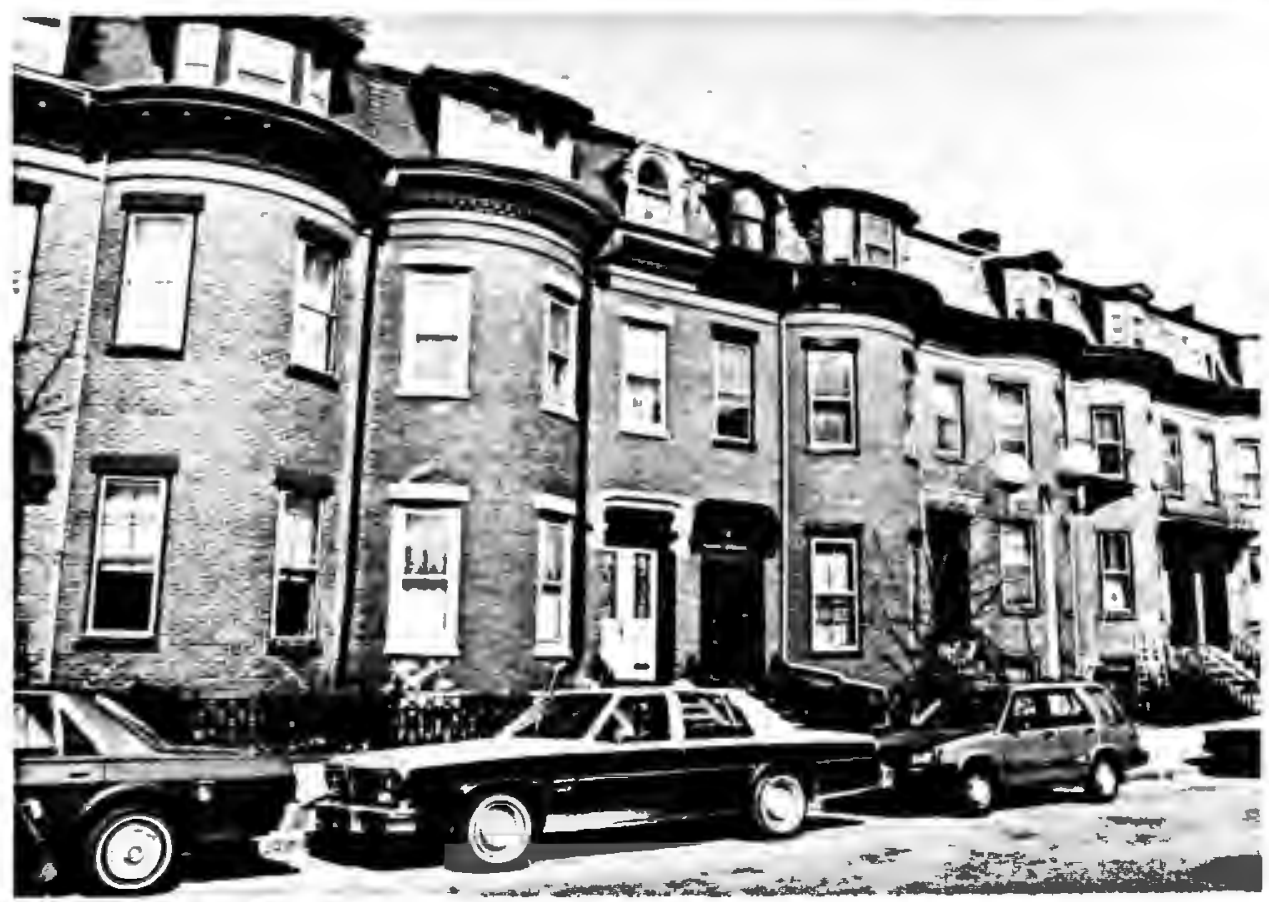

171 MARREN AVENUE

$2 B R \$ 115,000$ 

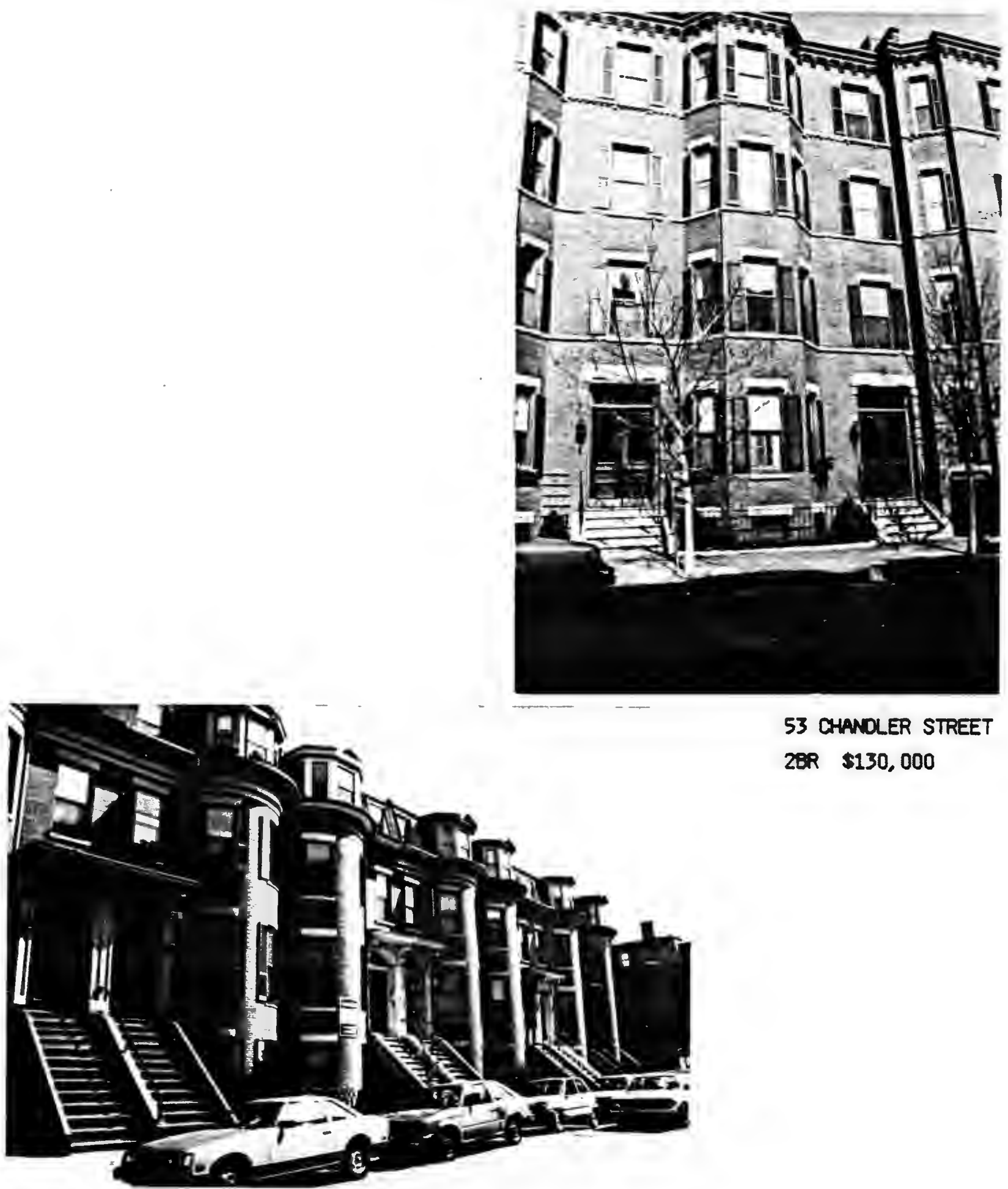

53 CHANOLER STREET $2 B R \$ 130,000$

*. CANTON STREET

2 BR $\$ 148,000$ 
Comparable Condominium Sales Data ${ }^{5}$

\begin{tabular}{|c|c|c|c|c|}
\hline & ADDRESS & SQ. FT./ BEDROOMS & PRICE * & AMENITIES \\
\hline \multirow[t]{4}{*}{$11 \mathrm{~A}$} & Appleton St. & $950^{\mathrm{s} . \mathrm{f}} \cdot / 2$ bdrms & $\$ 103,000$ & \\
\hline & $\begin{array}{l}\text { Appleton St. \& } \\
\text { West Canton }\end{array}$ & $/ 1$ bdrm & $\$ 63,000$. & $\begin{array}{l}\text { fireplace, hardwood } \\
\text { floors }\end{array}$ \\
\hline & $\begin{array}{l}\text { Appleton St.\& } \\
\text { West Canton }\end{array}$ & $/ 2$ bdrm & $\$ 125,000$. & \\
\hline & Appleton St. & $\begin{array}{l}700^{\text {s.f. }} / 1 \mathrm{bdrm} \\
\text { s.f. }\end{array}$ & $\$ 62,000$ & AC, 2 level loft \\
\hline 50 & Berkley St. & $\begin{array}{l}635 / 1 \text { bdrm } \\
\text { s.f. }\end{array}$ & $\$ 70,000$ & \\
\hline 50 & Berkley St. & $\begin{array}{l}872 / 2 \text { bdrms } \\
\text { s.f. }\end{array}$ & $\$ 97,000$ & \\
\hline 50 & Berkely St. & $\begin{array}{l}872 \quad / 2 \text { bdrms } \\
\text { s.f. }\end{array}$ & $\$ 98,500$ & \\
\hline 53 & Chandler St. & $\begin{array}{c}1581 / 2 \text { bdrms } \\
\text { s.f. }\end{array}$ & $\$ 130,000$ & \\
\hline 73 & Dartmouth & $\begin{array}{l}1000 \quad / 2 \text { bdrms } \\
\text { s.f. }\end{array}$ & $\$ 130,000$ & \\
\hline \multirow[t]{2}{*}{127} & Penb roke St. & $800 \quad / 2$ bdrms & $\$ 90,000$ & $\begin{array}{l}\text { hardwood floors, pri- } \\
\text { vate decks, parking }\end{array}$ \\
\hline & Rutland Sq. & $\begin{array}{l}\text { s.f. } \\
\text { s bdrm }\end{array}$ & $\$ 70,000$ & \\
\hline 604 & Tremont St. & $1020 / 2$ bdrms & $\$ 98,500$. & $\begin{array}{l}\text { penthouse with roof } \\
\text { rights, parking }\end{array}$ \\
\hline 3 & Union $\mathrm{Pk}$. & $/ 2$ bdrms & $\$ 104,000$. & $\begin{array}{l}A C \text {, fireplace, } 11 / 2 \\
\text { baths }\end{array}$ \\
\hline 3 & Union $\mathrm{Pk}$. & $/ 2$ bdrms & $\$ 165000$ & $\begin{array}{l}\text { lux penthouse, } A C, \\
\text { fireplace } 11 / 2 \\
\text { baths }\end{array}$ \\
\hline 33 & Union Pk. & $\begin{array}{l}940^{\text {s.f. }} / 2 \text { bdrms } \\
\text { s.f. }\end{array}$ & $\$ 112,000$ & \\
\hline & Union $\mathrm{Pk}$. & 950 s.f. $/ 2$ bdrms & $\$ 105,000$ & deck, AC \\
\hline 42 & Union $\mathrm{Pk}$. & $940 \quad / 1$ bdrm + study & $\$ 105,000$. & \\
\hline & Union Pk. & $/ 2$ bdrms & $\$ 108,000$ & \\
\hline
\end{tabular}

- In cases uhare the actual selling price was unavailable, peasible listing prices mere substituted. 


\section{Comparable Condominium Sales Data ${ }^{5}$}

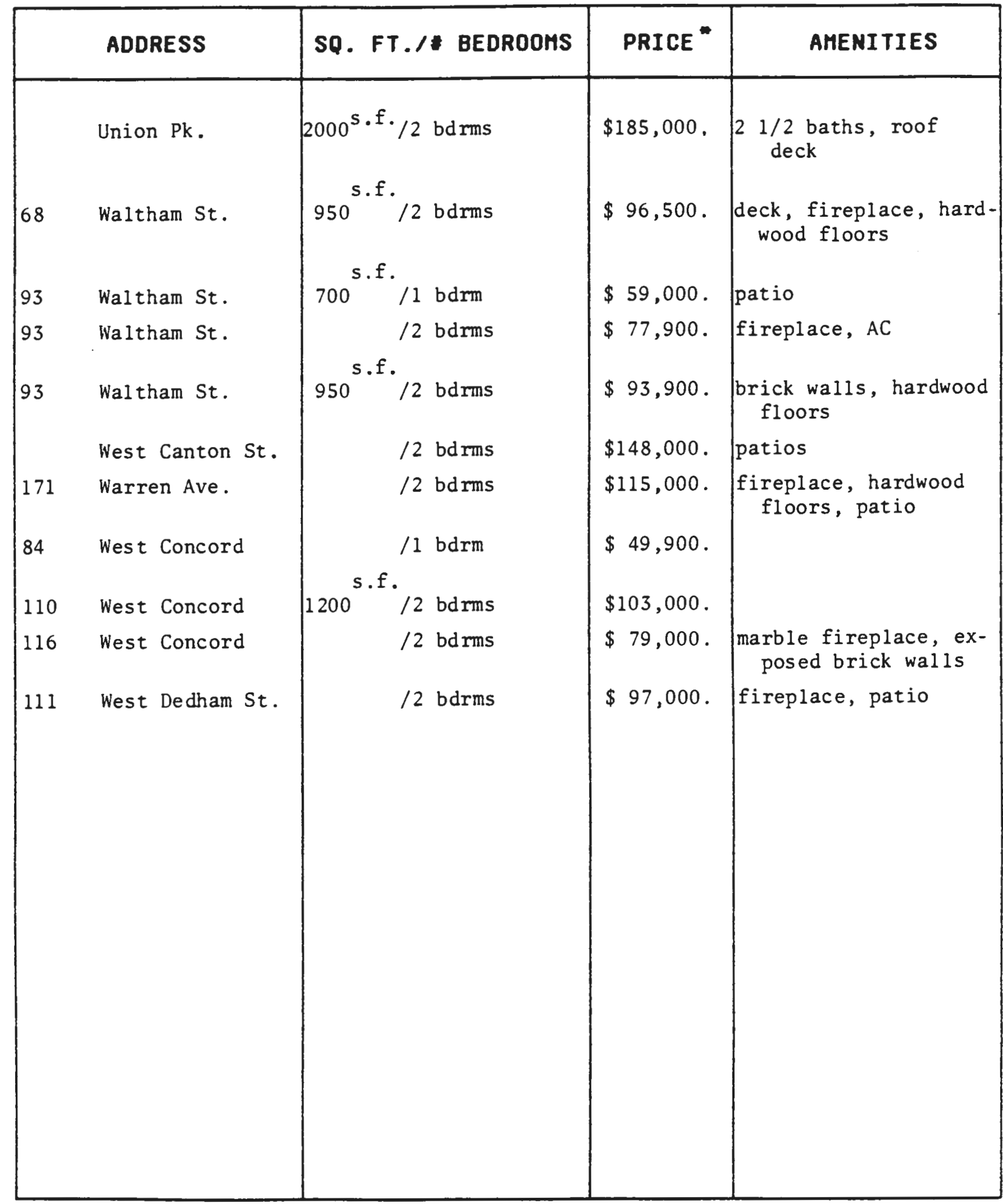

- In cases where the actual selling price was unovaileble, foosible listing prices were substituted. 


\section{Square Feet - Price ${ }^{6}$}

COMPARABLE CONDOMINIUMS

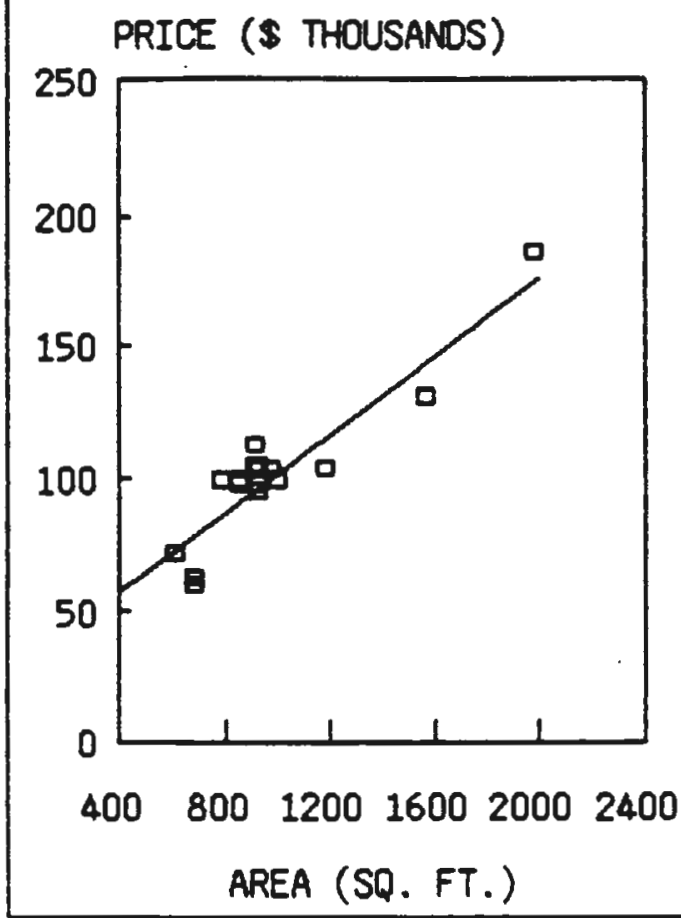

\section{PRICE}

MEDIAN: $\$ 98,500$

MODE : $\$ 103,000$

AREA

MEDIAN: 950 SQ. FT.

MODE: $950 \mathrm{SQ}$. FT.

REGRESSION LINE EQUATION

$Y=23.6+.08(x)$

CORRELATION COEFFICIENT

CORR $=.93$

\section{Price - * of Bedrooms ${ }^{7}$}

COMPARABLE CONDOMINIUHS

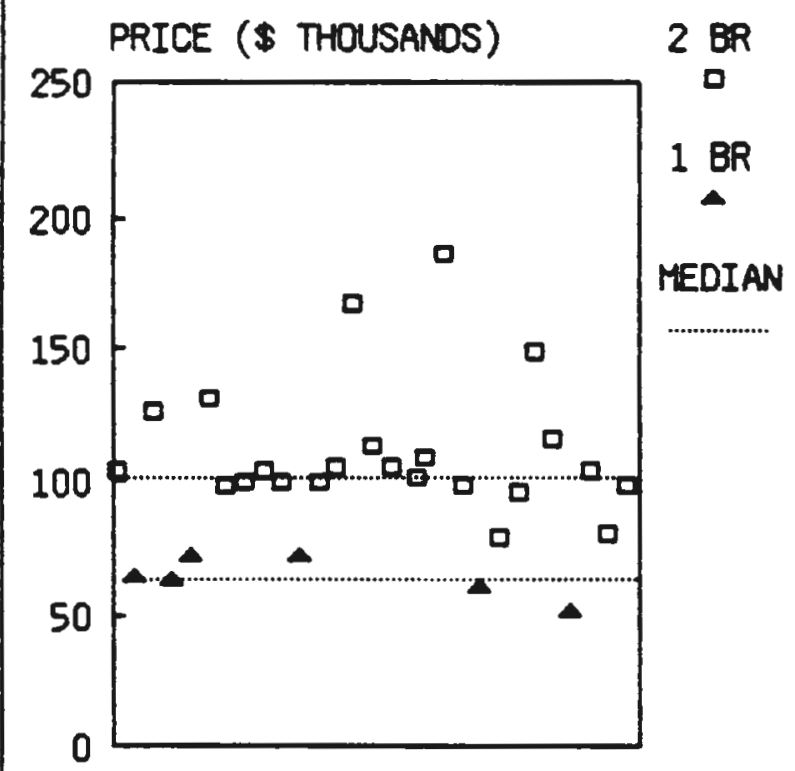

\section{BEDROOM CONDOMINIUMS}

MEDIAN PRICE: $\$ 103,000$

1 BEOROOM CONDOMINIUMS

MEDIAN PRICE: $\$ \$ 2,750$ 


\section{Commercial Development (1mmediate area)}

Some small scale commercial development has also occurred in the area. The majority of commercial activity is small retail establishments serving the needs of the growing resident population. A number of convenience markets and specialty stores have recently located in the immediate neighborhood, as well as a new restaurant on Dartmouth Street. Commercial activity is still the exception rather than the rule as the area remains almost entirely residential.

\section{Mixed Use Development (surrounding area)}

A number of large scale mixed use development projects within relatively close proximity to the site are currently underway or recently completed. These successful projects contribute to the revitalization potential of the Back Bay/South End transitional zone surrounding the Bancroft-Rice School. The following projects are situated only a short distance from the site:

\section{Copley Place}

The most significant of these new development projects is Copley Place. It is a large scale mixed use development reminiscent of such grand Boston undertakings as Government Center, Downtown Crossing and Quincy Market. The 300 million dollar project received one of the largest UDAG's ever granted ( $\$ 18.8$ million). The components include two hotels, a health club, 8 cinemas, two office towers, and $720,000 \mathrm{sq} . \mathrm{ft}$. of retail (anchor stores, mall shops and restaurants). This development adds prestige to the area and provides a large variety of

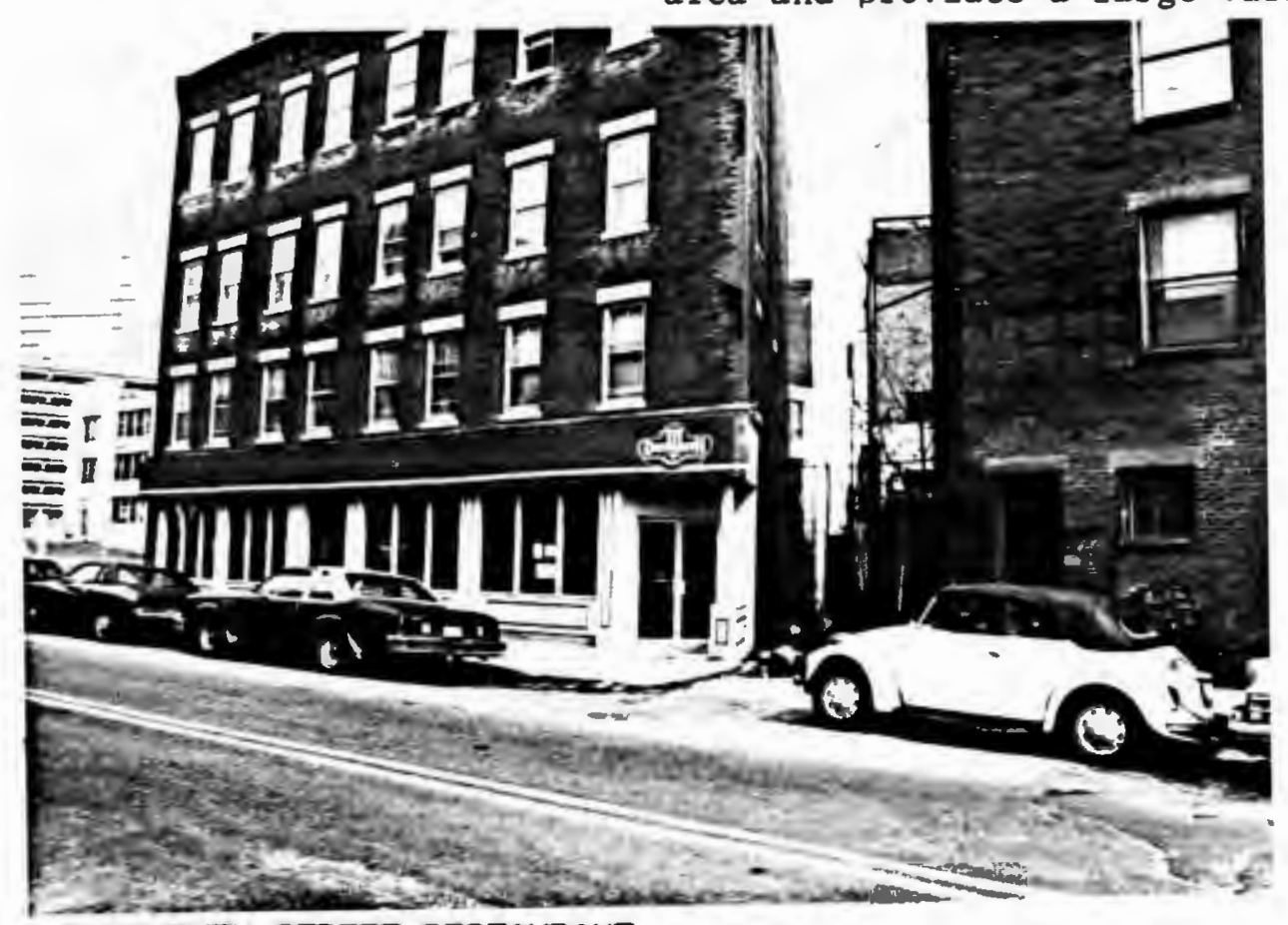

DARTIOUTH STREET RESTALRANT 
entertainment and shopping opportunities within walking distance of the Bancroft-Rice site

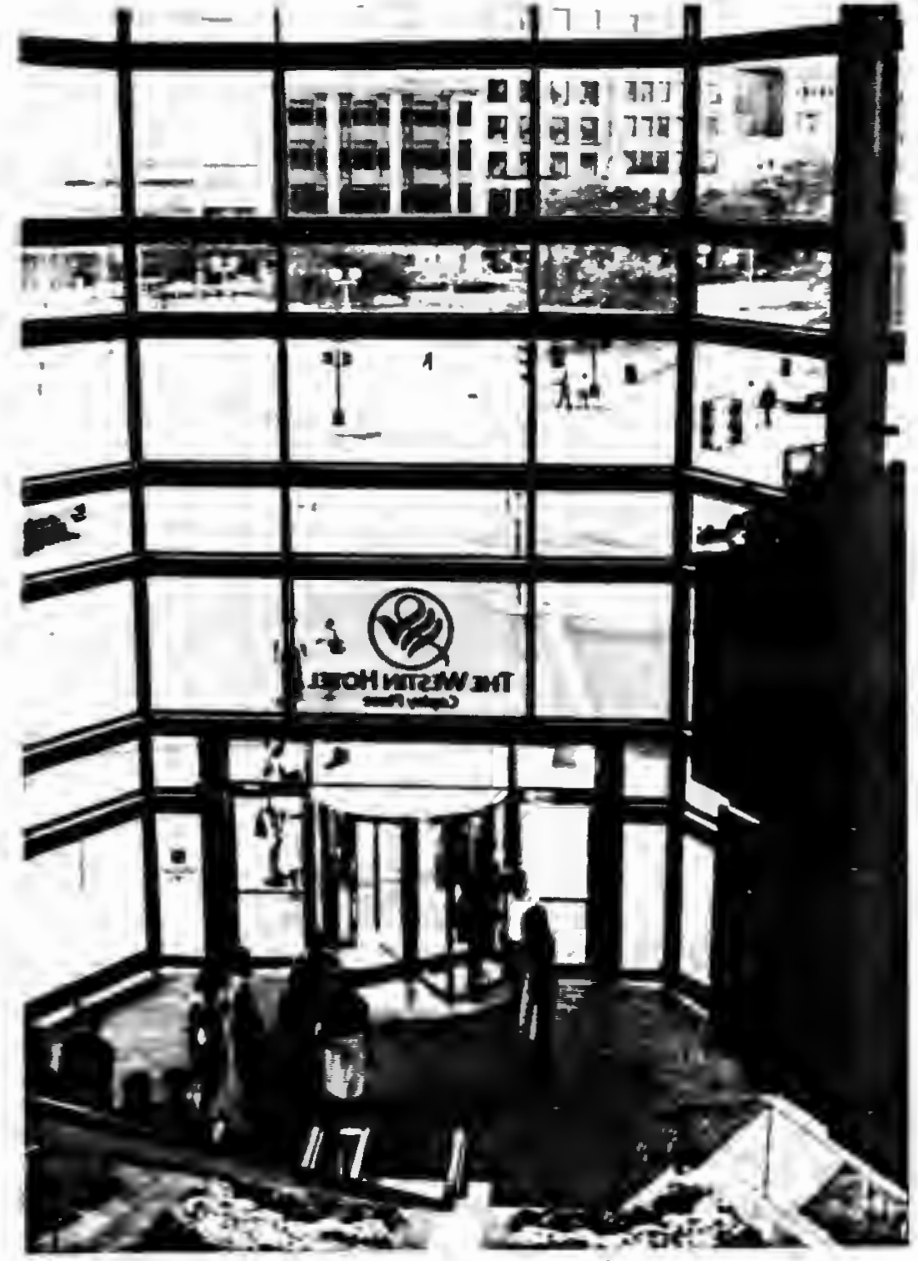

COPLEY PLACE

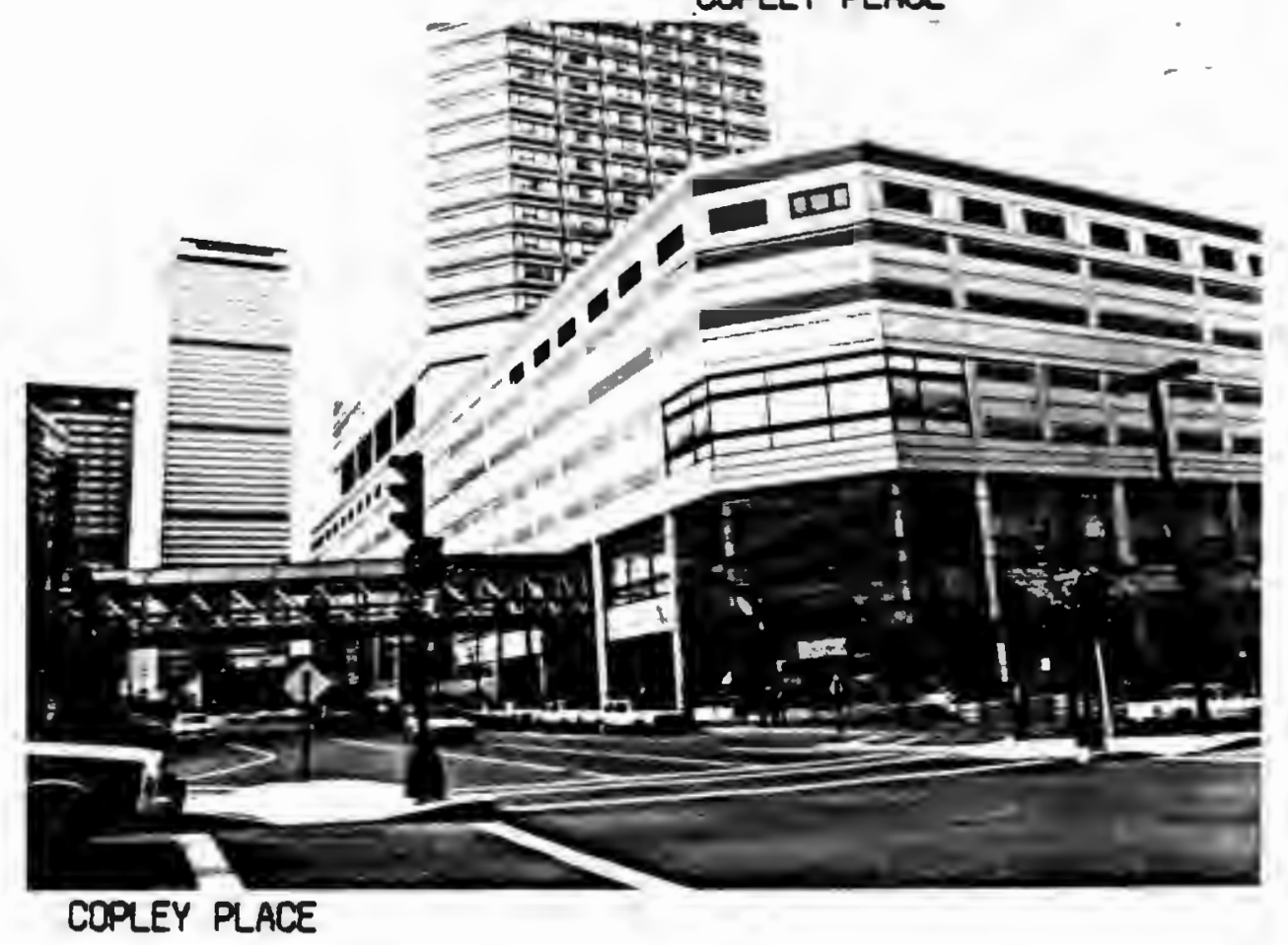




\section{Exeter Tower I and Exeter Tower II}

This attractive $\$ 10$ million project will include both luxury rental units and retail. Tower I, located at Exeter and Newbury Streets, has been completed and contains 96 housing units and 6,000 sq.ft. of retail space Tower II is located currently under construction and will be very similiar in composition.

\section{The Greenhouse Apartments}

The recently completed Greenhouse Apartments are located at the fringe of what is generally considered Back Bay, bordering on the speculative South End Neighborhood. The two 12 story towers are connected by a glass greenhouse type structure. This $\$ 17$ million project contains 306 luxury housing units and $8,000 \mathrm{sq} . \mathrm{ft}$. of retail. The majority of apartments overlook the spectacular Christian Science Center Complex.

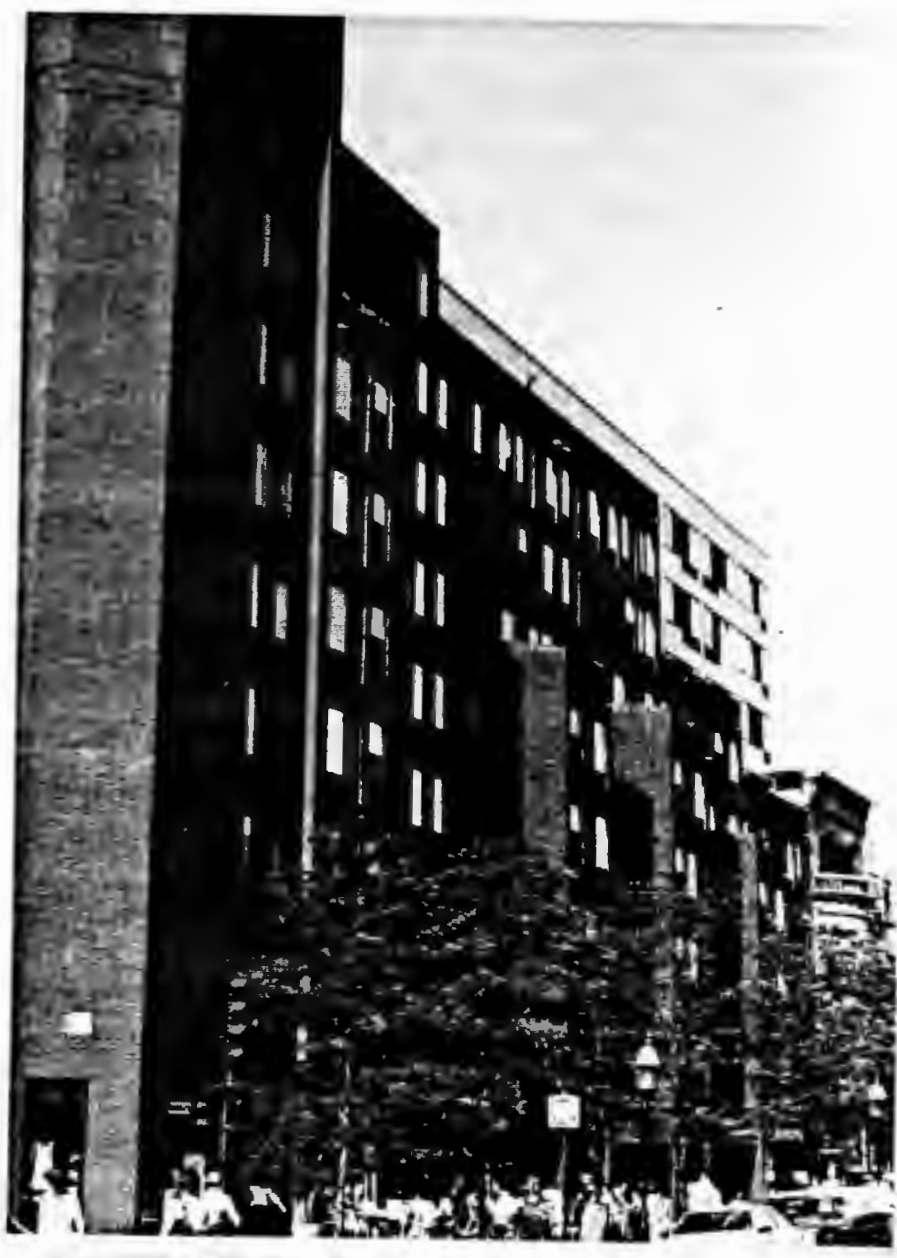

EXETER TOWER

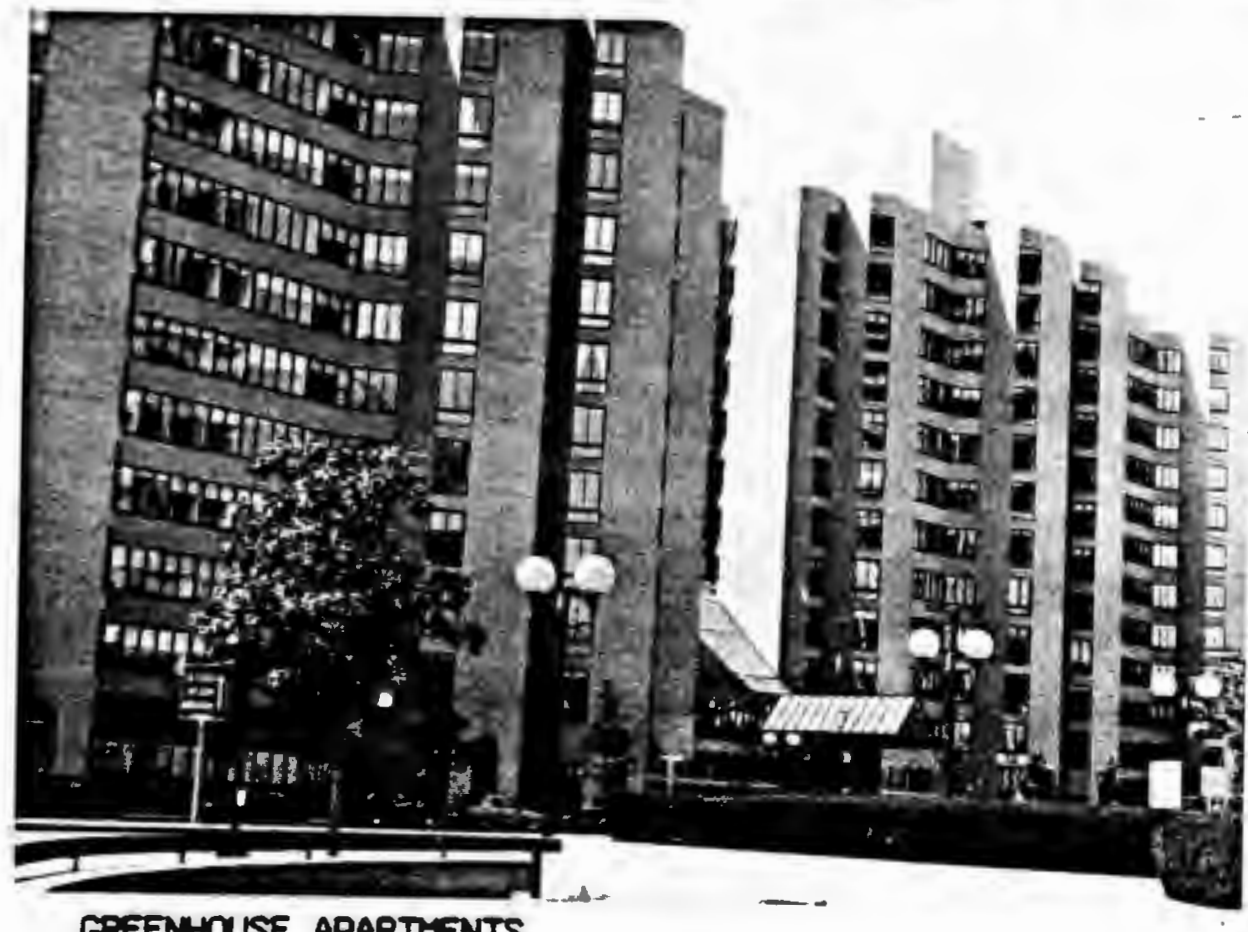

GREENHOUSE APARTIENTS 


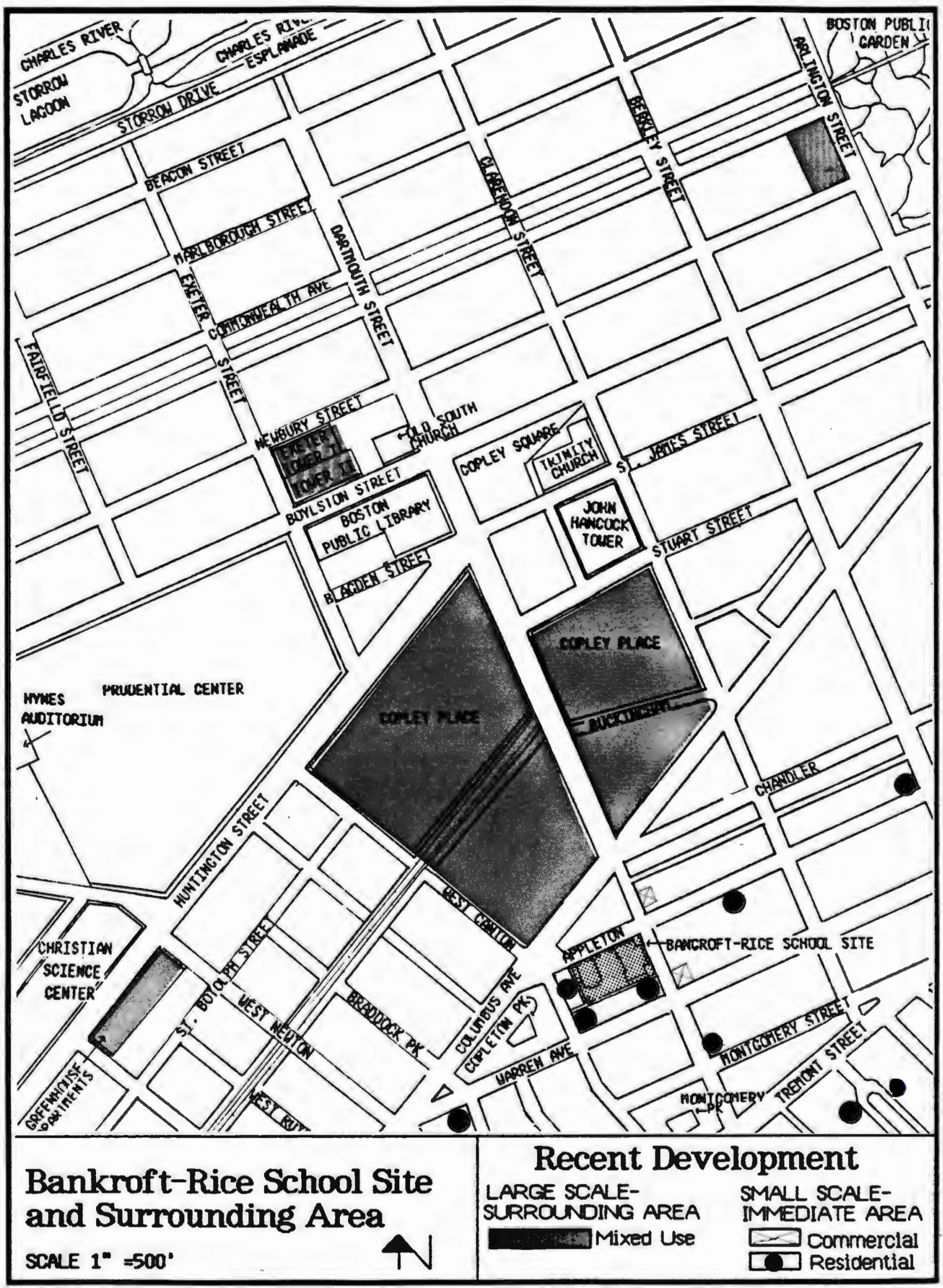




\section{Projected Housing Demand}

The 1985 projected tract populations assuming that the 1970-1980 trend will continue (as predicted by the preceeding indicators), is estimated at 2,159 . This represents an increase of 576 people or approximately 362 households. When compared to the 95 vacant units reported in the 1980 Census, there appears an excess of 267 units. Assuming an even absorbtion over the five year period from 1980-1985, there would be an expected demand of $53 \mathrm{u}$ nits annually. A closer examination. of the vacant housing units reported within the Census tract reveals that a large number were located in delapidated buildings. If half of the vacant units are assumed deteriorated and not counted as part of the viable supply, the excess projected demand is 314 units over 5 years of 63 units annually. There is no guaruntee that current trends will continue and this demand will be realized, however the indicators studied thus far point in that direction. In addition, there is always the possibility that introducing housing units of the most popular size, price and amenity features into the market will create their own demand and attract residents who many otherwise have settled in adjacent areas.

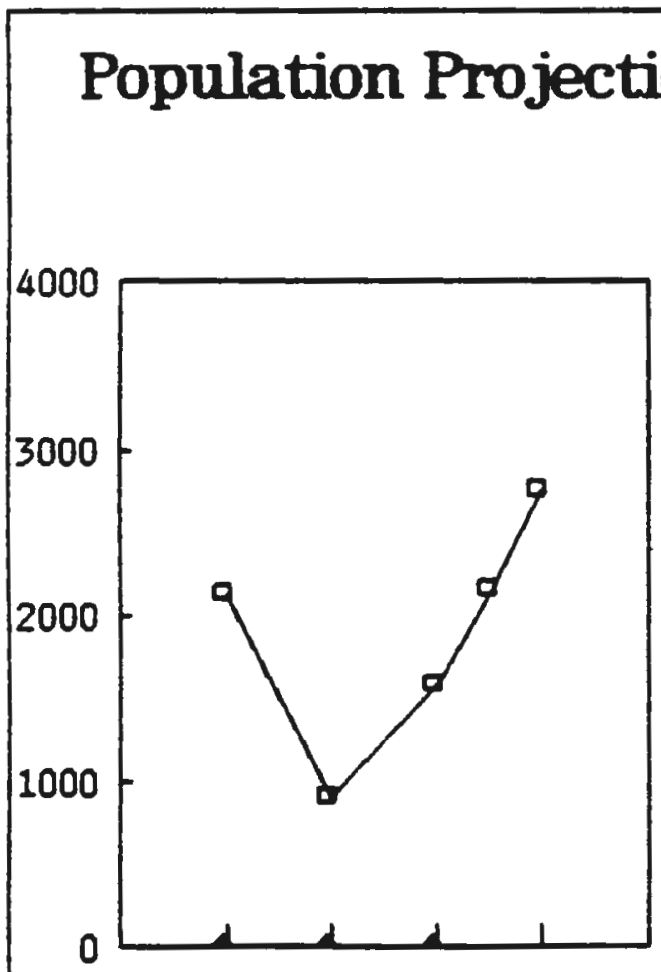

195019601970198019902000

U.S. Census of Pop. and Housing 1960.70 680
- Ratio Projection assuning 1970-80 trend wil continue

\section{Housing Unit Demand}

1985 PROJECTED POULATION INCREASE TRANSFORHED TO NO. OF UNITS 576/1.59* = 362

NO. OF VACANT UNITS 1980

EXCESS DEMAND 1980-85 267

ABSOREED OUER 5 YRS. 53 LNTS ANUALY

-NO. OF VACANT UNITS 1980 48

EXCESS DEMAND $1980-85$ 314 ABSOPEED OVER 5 YRS. 63 LNITS ANUALY

*Asuning 1/2 vecant units deteiorated and should not be counted as suply

- Tiedien persons per housenolo 


\section{Competing Housing.}

\section{Projects}

There is currently only one evident housing project underway in the immediate area. It is located at the corner of Dartmouth and Warren. It is a small project resulting in approximately 12 units. The structure has considerauly less architectural interest than the Bancroft-Rice School and no off-street parking is provided. It is not known how many other projects currently may be in the planning stage about to commense. There has been significant redevelopment activity in the area and it is reasonable to expect that other development projects may be initiated in the near future in response to the perceived demand. Therefore if the site is to be redeveloped, it is imperative that the project move along as quickly as possible.

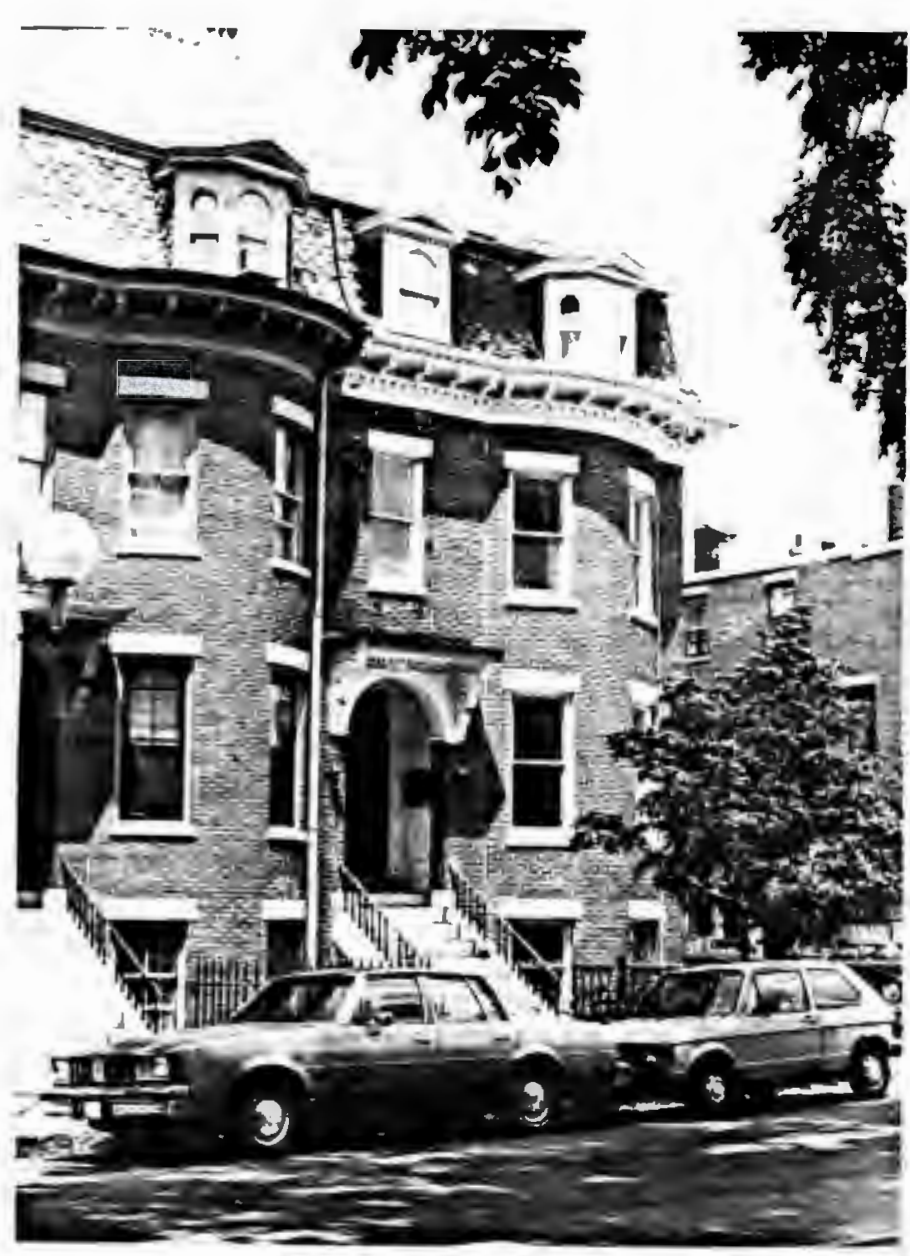

WARREN AVENUE CONOOMINIUTS 


\section{Market Analysis Summary... parameters FOR OPTIMUH DEVELOPHENT}

The following summary presents the condensed findings of the market analysis and indicates the resulting parameters for optimum development of the site.

\section{GENERAL USE: RESIDENTIAL}

The indirect economic factors, in particular, the existing composition of the neighborhood and current zoning, limit the potential viable uses for the site to primarily residential development. A small number of professional offices may be considered as part of a mixed use development but this would constitute a relatively new, untested use for the area.

\section{ESTIMATED HOUSING DEMAND: LOV 267 UNITS (53 UNITS ANNUALLY) \\ MED 314 UNITS (63 UNITS ANNUALLY) \\ HIGH DEMAND CREATED BY NEU UNITS}

There appears to be an increasing demand for housing in the immediate area. Many factors contribute to the area's renewed popularity: readily available services, proximity to the prestigous Back Bay, access to transportation, neighboring points of interest, etc. These elements have attracted a new group composed primarily of young childless professionals with relatively high incomes.

This influx of population is expected to continue, creating an excess demand over the next several years. The preceeding table attempts to quantify this demand. The low estimated figure assumes that all existing vacant units must be filled before there is an excess demand. The medium figure assumes that approximately
$1 / 2$ of the vacant units exist in deteriorated buildings and should not be counted as part of the viable supply. Although no specific estimate is given, the table also indicates the possibility that the new development, if composed of outstanding units with popular characteristics, may create its own demand and attract people who may have otherwise settled in adjacen

\section{SPECIFIC USE: CONDOMINIUMS}

One of the major attractions of potential residential development of the Bancroft-Rice site is the prospect for home ownership at close to the monthly cost of renting in the neighboring Back Bay. The typical new housing consumer in the area earns, an income high enough to dictate the need for the tax benefits of ownership. In addition, the expected high cost of renovation may well require rent levels to be set only slightly lower than those of Back Bay. Very few high priced, luxury rental units currently exist in the South End. Most renters willing to pay high prices seem to demonstrate a preference for more established and prestigous areas.

\section{SIZE AND PRICE OF UNITS:}

1 BR. $\quad \$ 65,000-75,000$
2 BR. $\quad \$ 90,000-100,000$

1 BR. APPROX. 700 SQ. FT.

2 BR. APPROX. 950 SQ. FT.

Examination of recently constructed (and sold) condominiums in the area reveals that the most popular units have two bedrooms, approximately 950 sq.ft. and are priced around $\$ 110,000$. 
One bedroom units are slightly smaller and prices range the mid 60 's to mid 70 's. This is consistent with the perceived needs of the target population.

\section{AMMENITIES TO INCLUDE:}

\section{DECKS, PATIOS, FIREPLACES, PARKING}

\section{AMD HARD NOOD FLOORS}

An informal survey of area realtors combined with the investigation of recent sales indicates that these amenities improve marketability.

\section{ADDITIONAL INCENTIVE:}

\section{DEVELOPER FIMAMCIMG}

The analysis of the target population indicates that the majority of cousing consumers have a sizable in. come but may have difficulty meeting lown payment requirements. Developer financing with adjusted terms sensitive to this dilema could significant. ly enhance demand for the units. This is particularly true in the case of attracting current Back Bay renters who could purchase for close to their present monthly rent if the burden of a down payment was lessened. 


\section{Chapter IV}

\section{Description of the Project}

The parameters for optimum development of the site suggested in Chapter III are employed in the following chapter to formulate two developmen $\tau$ alternatives. The first, the basic development alternative, consists entirely of residential condominiums. The second development option represents a variation of the first, consisting primarily of residential condominiums with offices on the first floor of both buildings. A complete descriptinn accompanies both alternatives including the sizes, prices, and amenities of the units as well as the financing arrangements and detailed construction cost estimate. Sketch plans and elevation drawings are included to illustrate the layout of the buildings and parking lot. The final section of the chapter describes the option of providing developer assisted mortgage arrangements for condominium purchasers. This option along with both development alternatives will then be thoroughly analyzed for financial feasibility in the following chapter.

\section{A. Basic Development} Alternative - Residential

\section{Condominiums}

LAYOUT

The suggested layout of both buildings is illustrated on the following pages. Living spaces are arranged in a manner which takes the most advantage of walls with windows. $\mathrm{Kitchens}$ and bathrooms are situated near the central core of each building so as to simplify plumbing system design. All units will be entered via the central hallway. There will be a limited number of exterior entrances to each building in order to reduce security risks. The Bancroft has two entrances, one from the parking lot on the first floor and one from Appleton Street on the second floor. The Rice has three entrances, one from the parking lot on the first floor and two on the second floor, one from Appleton Street and one from Dartmouth Street.
The possibility of expanding the buildings either vertically or horizontally was considered. However, the potential destruction of the historic character of the buildings and difficulty in obtaining variances makes this option unattractive. CONDOMINIUM UNITS

The layout of the buildings comfortably allows a total of 46 units, 38 two bedroom and 8 one bedroom. This quantity is well within demand projections cited in the market analysis. Significantly fewer one bedroom units are included as they appear to be less popular in the South End.

The two bedroom units generously average 950-1,050 square feet of living space paralleling the currently most marketable units in the area. The one bedroom units approximate 700 square feet.

\section{AMENITIES AND SPECIAL FEATURES}

ROOF DECK AND TERRACES

Usable outdoor space is a reoccurring feature in newly renovative properties of the neighborhood which seems to improve sales appeal. Although a great deal of open area exists between the buildings, it does not lend itself to a court yard or other passive recreational use. This is mainly due to three factors: 1) the area is ten feet below street level with very little light and no prifacy, 2) the area would directly abut the parking area with its accompanying noise and smell of exhaust, and final1y 3) this space could be better used for additional parking. Consequently, with the ground level not an option, the alternatives are reduced to roof decks and terraces.

The Bancroft building is well suited for a roof garden because it has a completely flat roof with no architectural detail. The common roof deck would provide residents a place for outdoor cooking, dining and sun-bathing which would be secure and private. In addition, the vegetation private. In in a.......1 d :-nman +ho 
4 are BeDroon UITS 24 TLO BEPROON WITTS 38 UnITs Totr

\section{Rice Building}

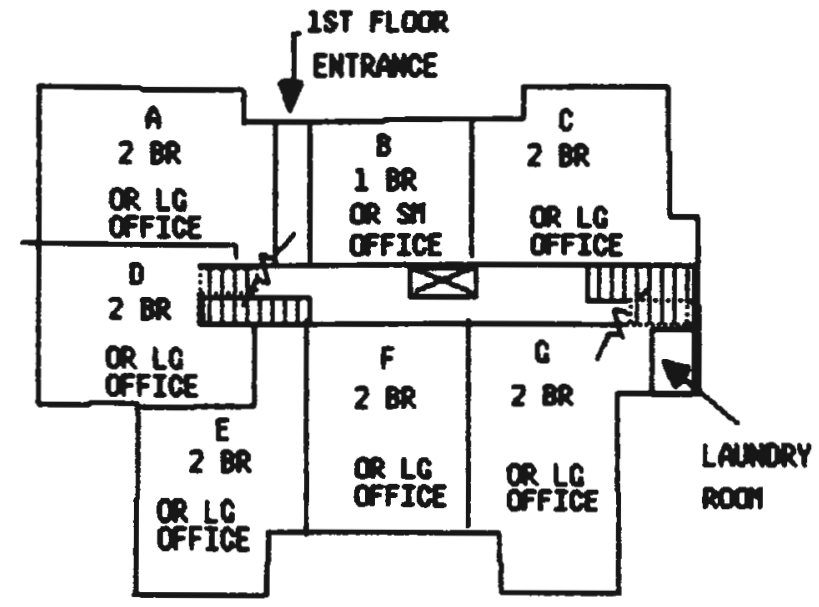

1st Floor

RES./OFFICE CONDOMINIUHS
$A \$ 85,000$
$E \$ 90,000$
A $\$ 500 / M 0$
E $\$ 700 / M O$
$B \$ 65,000$ F $\$ 90,000$
B $\$ 500 / 10$
$F \$ 700 / 10$
C $\$ 90,000$ G $\$ 90,000$
C $\$ 700 / 110$
$G \$ 700 / 10$
D $\$ 85,000$
D $\$ 500 / \mathrm{MO}$

OFFICE RENTALS
4 ane Besion untTs

CR (1) 26 UITs Total

an

1 SIFU OFFICE 6 LAPTE OFFTCES 7 OFFICE REMTALS

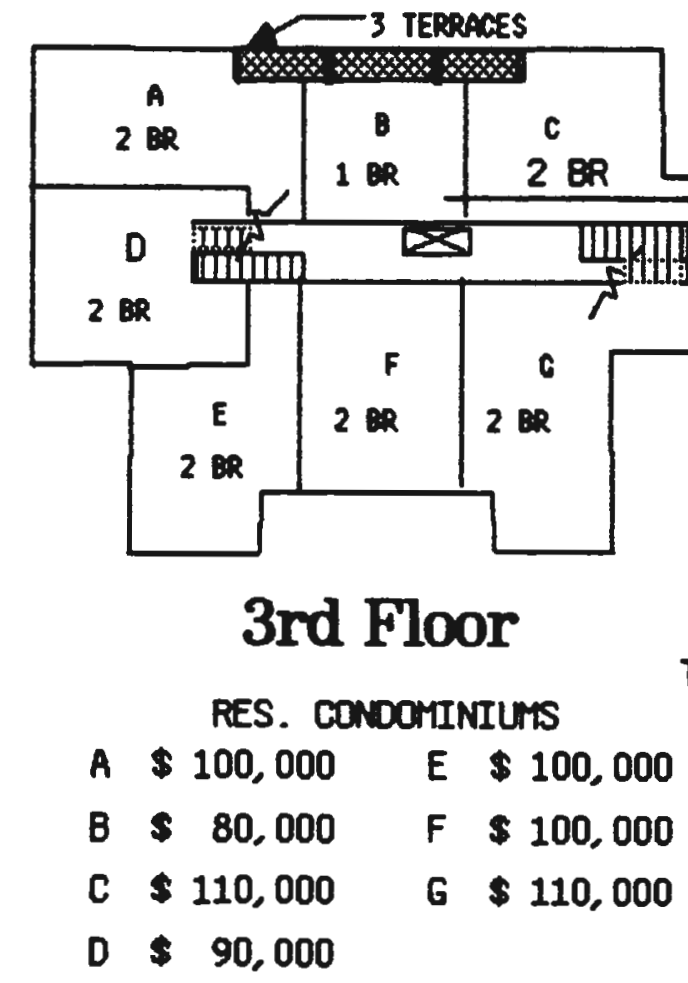

SCALE $1^{\prime \prime}=40^{\circ}$

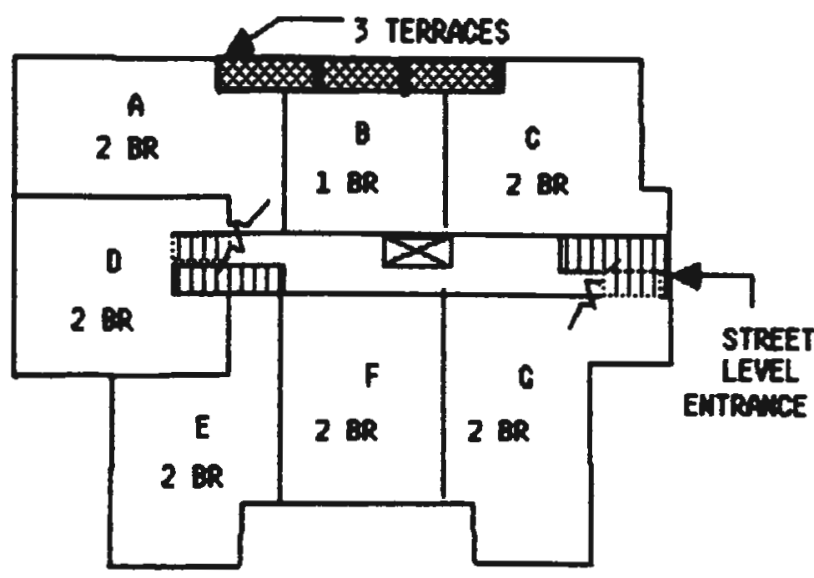

2nd Floor RES. CONDOMINIUUS
A $\$ 100,000$
E $\$ 100,000$
$B \$ 80,000$
$F \$ 100,000$
C $\$ 110,000$
$G \$ 110,000$
D $\$ 90,000$

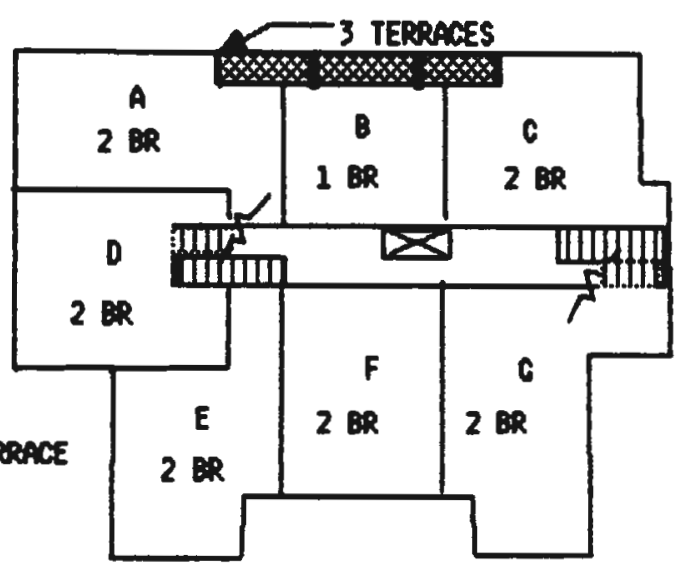

4th Floor

RES. CONDOMINTUNS
TYPICAL LAYOUT
$A \$ 100,000$
$E \$ 100,000$
$B \leqslant 80,000$
$\$ 100,000$
D $\$ 90,000$

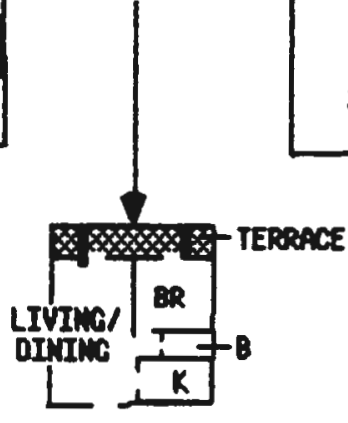




\section{4 one gevesean unats

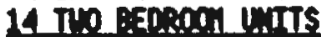 28 uats TOTM \\ Bancroft Building \\ a $11 \pi 00200001$ 13 UITS \\ And \\ 2 MMLL OFFIOES \\ 3 Leire OFFICES \\ 5 OFFICE RentaLs}

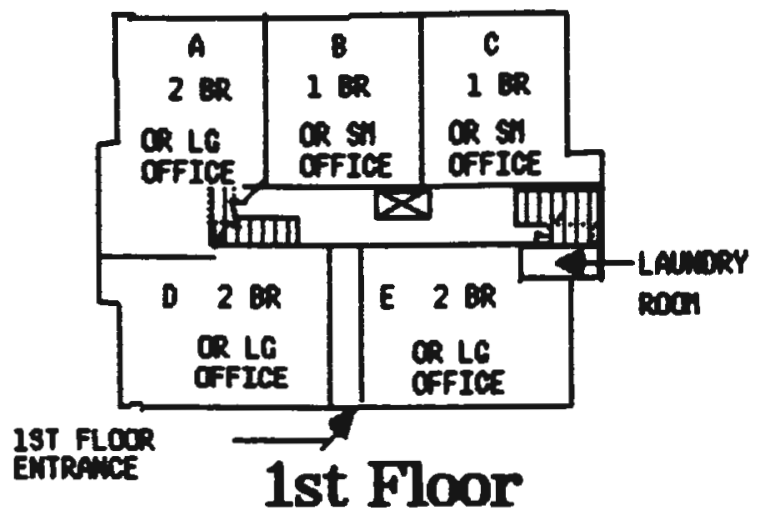

RES./OFFICE CONDOMINIUTS

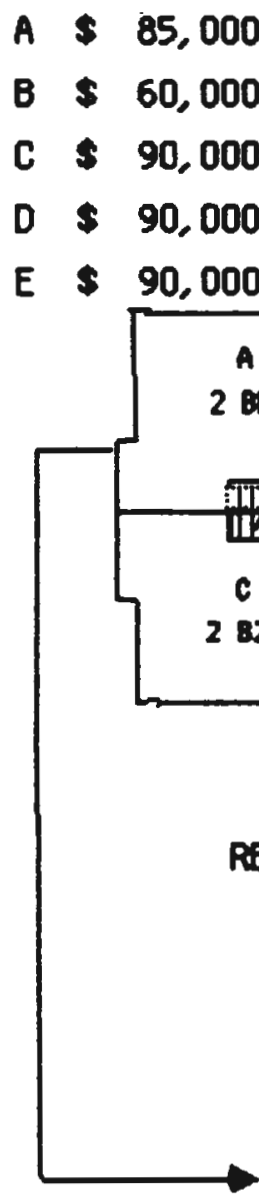

A $\$ 85,000$

OFFICE RENTALS

$B \$ 60,000$

A $\$ 600 / M 0$

B $\$ 500 / \mathrm{m}$

C $\$ 500 / 10$

D \$700/10

E $\$ 90,000$

E $\$ 700 / 10$

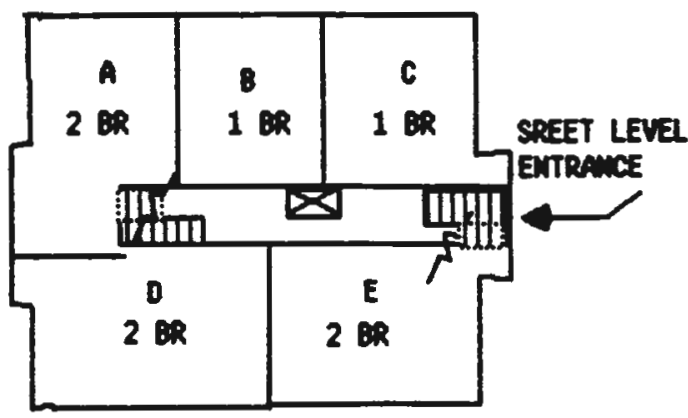

2nd Floor

RES. CONDOHINIUNS

A $\$ 90,000$

B $\$ 65,000$

C $\$ 75,000$

D $\$ 100,000$

E $\$ 110,000$

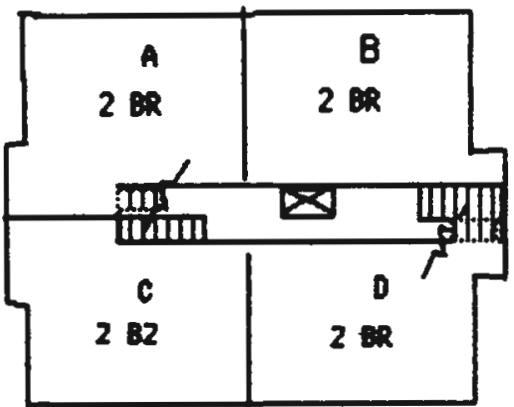

\section{4th Floor}

PES. CONDOMINIUNS
A $\$ 90,000$
B $\$ 110,000$
C $\$ 100,000$
D $\$ 110,000$

PARKING SPACES \$5, 000 EA

TYPICAL LAYOUT

SCALE 1" $=40^{\circ}$ 


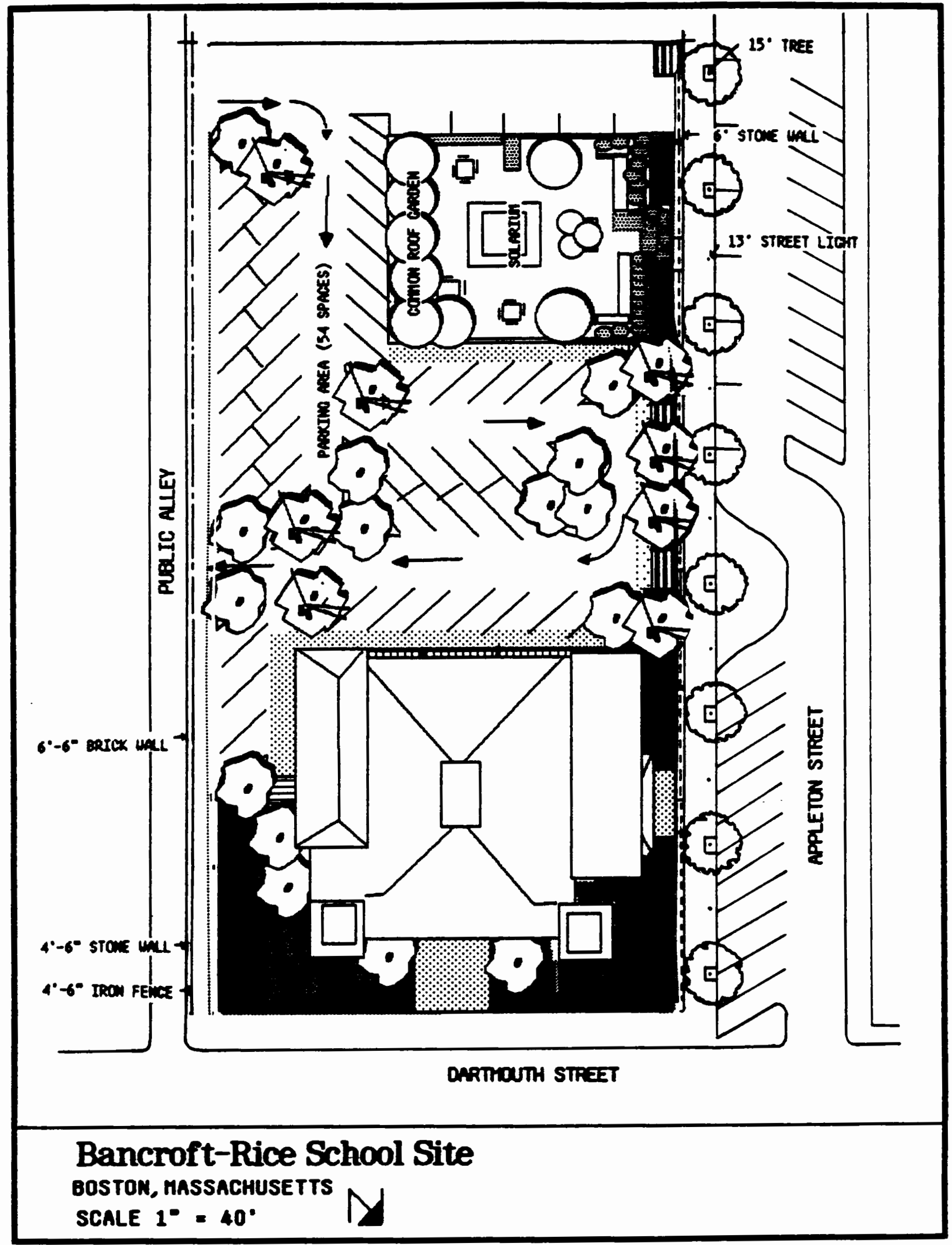


attractiveness of the building by giving the roof distinction. On the other hand, this is not appropriate for the Rice building with its well articulated mansard roof. Instead, the building seems to lend itself to terraces on its West side between the two comer pillars. This provides enough room to accomodate private terraces for three units on each of the above ground floors. These terraces would offer residents outdoor enjoyment and a pleasant view.

\section{PARK ING}

One of the most valuable amenities that Bancroft Place has to offer is on-site parking. Employing a 45 degree, one way system the lot will accomodate 54 spaces. These spaces would be sold with the units. At first the spaces would be allocated one to each unit. The remaining eight spaces would be offered for sale to owners of two bedroom units on a first come first serve basis. After the sale of units whose owners do not wish to purchase parking spaces, those too will be offered to future or recent buyers. Each space will be priced at $\$ 5,000$. (Parking space rental in the adjacent Back Bay area is $\$ 60-\$ 70$ per month.) The price may be raised or lowered depending on demand.

If any spaces remain after all the units are sold, they will be sold to the condominium as sociation and designated for visitor parking. A fee will then be incorporated into the monthly condominium fee to cover this cost. However, it is not expected that there will be many spaces, if any, leftover. (Even though there is resident street parking available, it is limited and offers no vehicle security.) The model assumes that 1.17 spaces will be sold with each unit projecting that all units will be eventually sold. (See "Alternative Development Option" for office parking space arrangements.)

\section{GOURMET KITCHENS}

The kitchens will contain top quality appliances including range, refrigerator, dishwasher and disposal. There will also be ample built-in cabinet space and a place for a microwave oven. The modern kitchens will provide an attractive draw for current back bay renters as most apartment kitchens in the area are poorly equipped.

\section{ELEVATORS}

An elevator will be installed in each building. Although four floor walk-ups are not at all uncommon in the area, the elevator is necessary to distinguish the condo complex as "luxury living."

\section{HARDWOOD FLOORS}

The living/dining room of each unit will be completed with hardwood floors. Although expensive to install, this feature promises to improve sale - ability of the units beyond the cost incurred. (as per market study information.)

\section{OTHER AMENITIES AND FEATURES}

Other amenities and features such as fireplaces and exposed brick walls were cited as popular additions in the market study. However, these items did not originally exist within the building and would be too expensive and architecturally obtrusive to be added now.

\section{EXTERIOR RENOVATION}

The buildings will be maticulously cleaned and resurfaced to restore the natural beauty of the masonry. The three existing entry ways will be repaired, stripped, sanded and stained. An additional entry way will be created on the first floor of each building. They will be compatible in style to the original street level doors. All windows be replaced with grav tint 


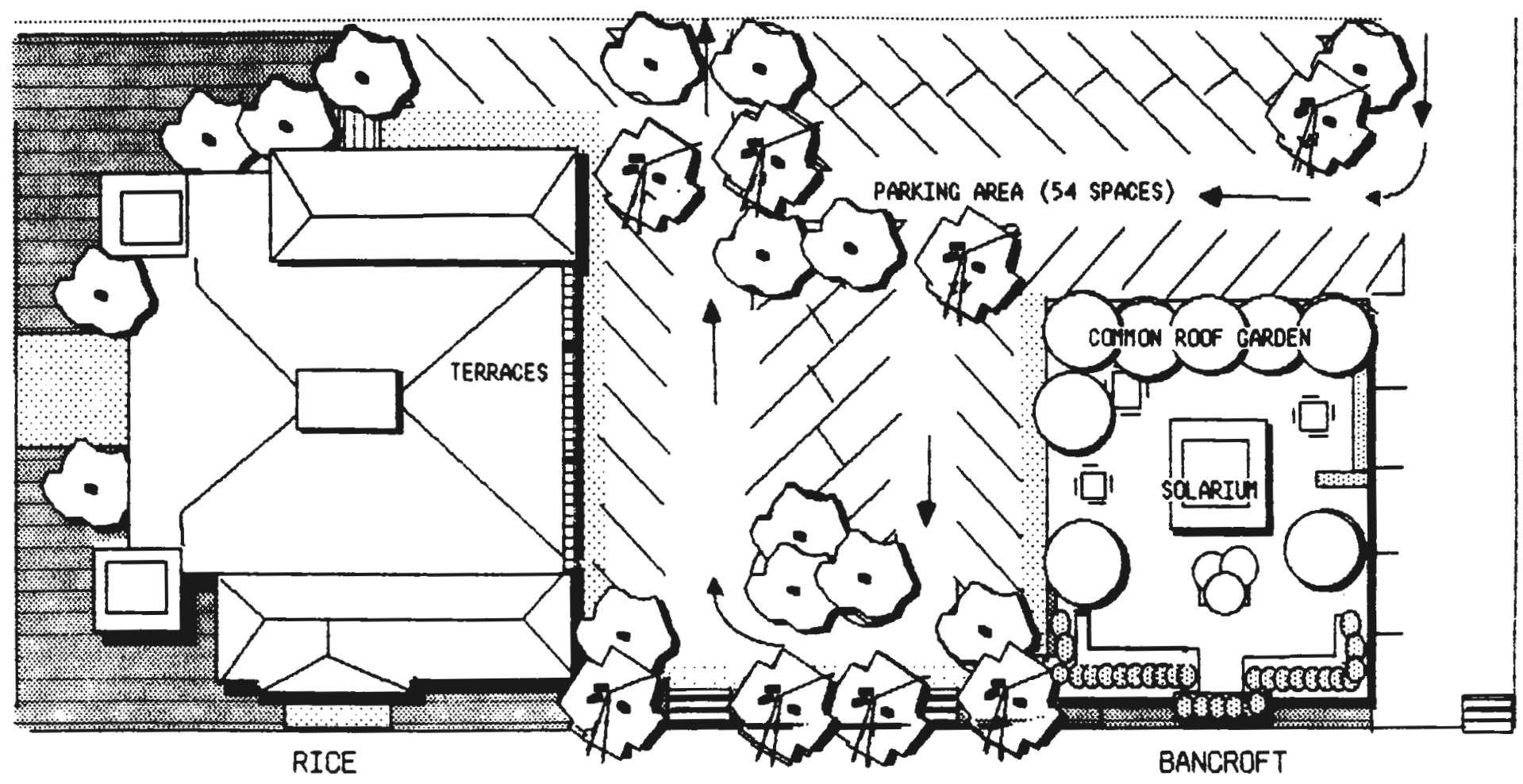

APPROXIMATE SCALE $1^{\circ}=40^{\circ}$

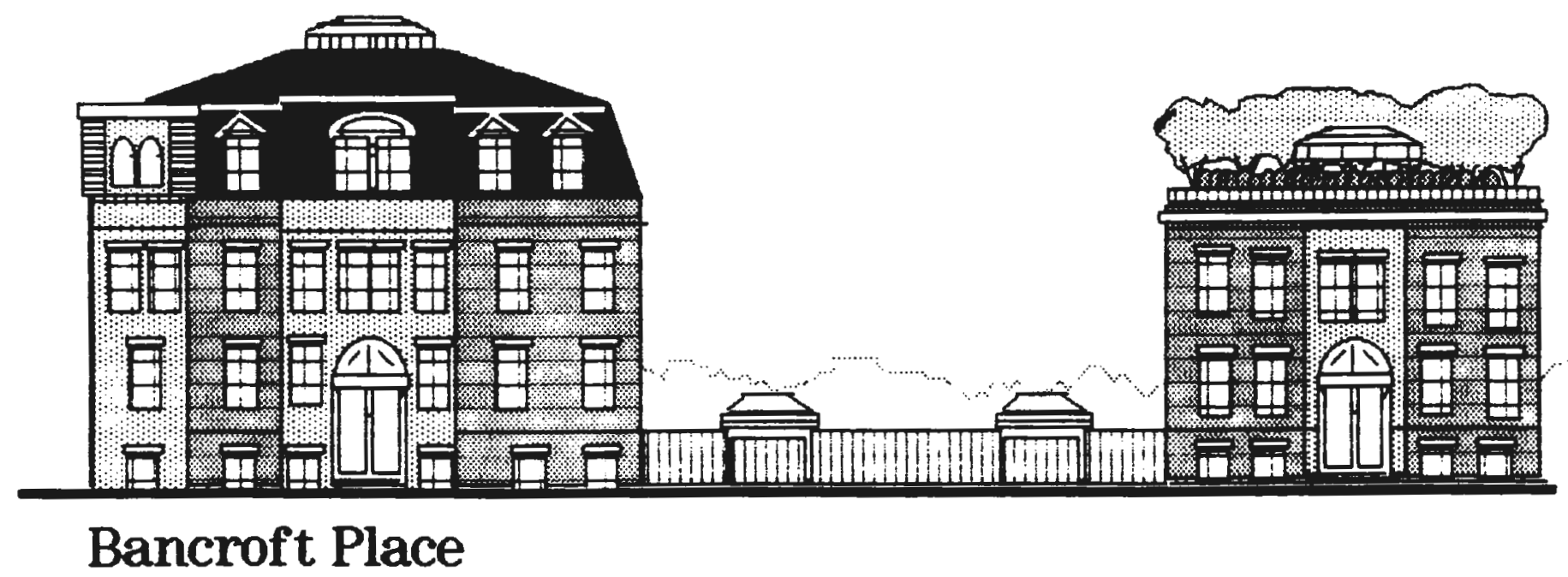


thermo panes and the roof will be repaired as necessary.

The terraces on the Rice building will be composed of black wrought iron in keeping with the historic character of the structure. The roof deck on the Bancroft will be patio floored with landscaping, benches, and a few tables. A solarium of gray tint thermo pane glass and black steel dividers will also be constructed to provide a sun room and receive the stairs from the fourth floor.

The existing walkways will be rehabbed and new ones will be created as illustrated on the sketch plan. The front and side yards as well as the parking lot will be generously landscaped with grass and hardy saltresistent trees. This is particularly important in the parking area to buffer the harsh visual impact of automobiles and improve the view from the lower level units.

PR ICE

Unit prices range from $\$ 65,000$ to $\$ 80,000$ for one bedroom units and from $\$ 85,000$ to $\$ 110,000$ for two bedroom units. These prices are compatible with the results of the market analysis. The individual condominiums are priced according to their amenity combinations. The suggested pricing is illustrated on the layout sketch plans. Bancroft Place offers a wide range of prices and unit styles to provide buying opportunity for many different types of consumers in the target group.

The first floor of both buildings contain the least desirable units. This is due to the less than pleasant view onto the parking lot or retaining wall and the increased security risk. Consequently, these units are priced lower than the upper floors. Their reduced marketability has prompted examination of an alternative to residential use which will be described later in the chapter.

Apart from the first floor, the main distinction in price lies with the quality of the view and the existence or non-existence of a terrace. In general the North facing units of both buildings and the East facing units of the Rice Building have the best views. For this reason they are priced slightly higher. The South facing units have a poor view, looking onto the parking lot and the alley. Although somewhat offset by the sunny exposure, these units are priced lower. The West facing units of the Bancroft Building have the worst view with little natural light, and consequently the lowest pricetag.

The terraces and roof deck add to the maretability and sales price of the units. Nine condos have terraces and are priced accordingly. The roof deck of the Bancroft adds to the value of all its units and offsets the fact that it is less architecturally interesting than the Rice.

\section{CONSTRUCTION COST}

A detailed estimate of the project renovation cost is described in the following table. The total cost is just over $\$ 2.5 \mathrm{million}$. This price includes approximately $\$ 100,000$ for site work; parking lot and grounds and 2.4 million for building rehab. This averages around $\$ 38$ per square foot. 


\section{Renovation Cost Estimate}

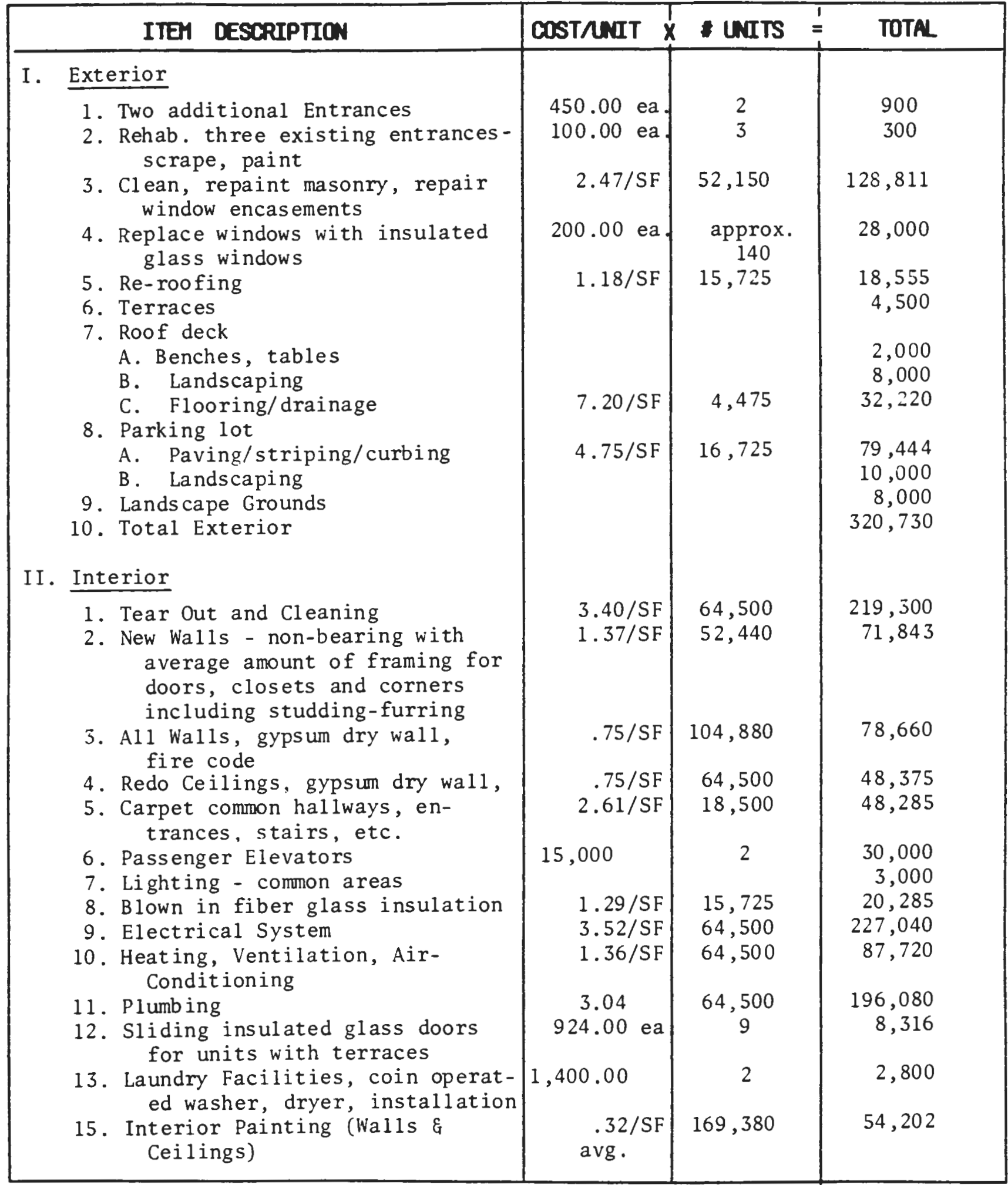

- SOURCE: HOIE-TECH REMOOELIMC AMD REMONATIOU COST ESTMATOR 1984. VO. 1. Field Manual. Henty Reynolds. Home-Tech Publications, Bochosds, Marylend,1924. 


\section{Renovation Cost Estimate (CoNTrued)}

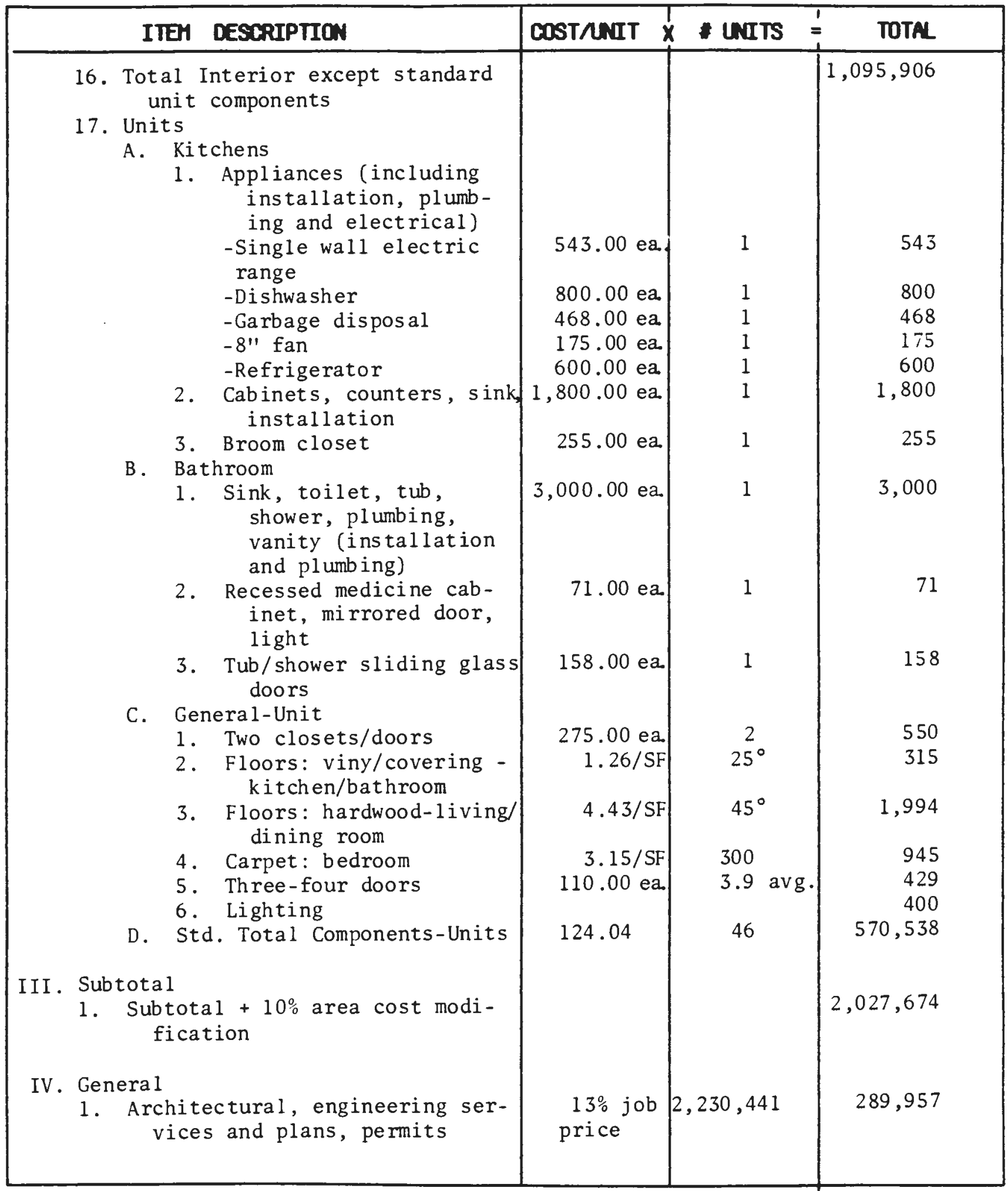

- SOURCE: HOHE-TECH REIOCELIMC AMD REHOUATIOY COST ESTIMATCR 1984. VOL. 1. Field Manual. Honty Reynolds. Hone-Tech Publications, Bothosda, farylend, 1984. 


\section{Renovation Cost Estimate (Contrmed)}

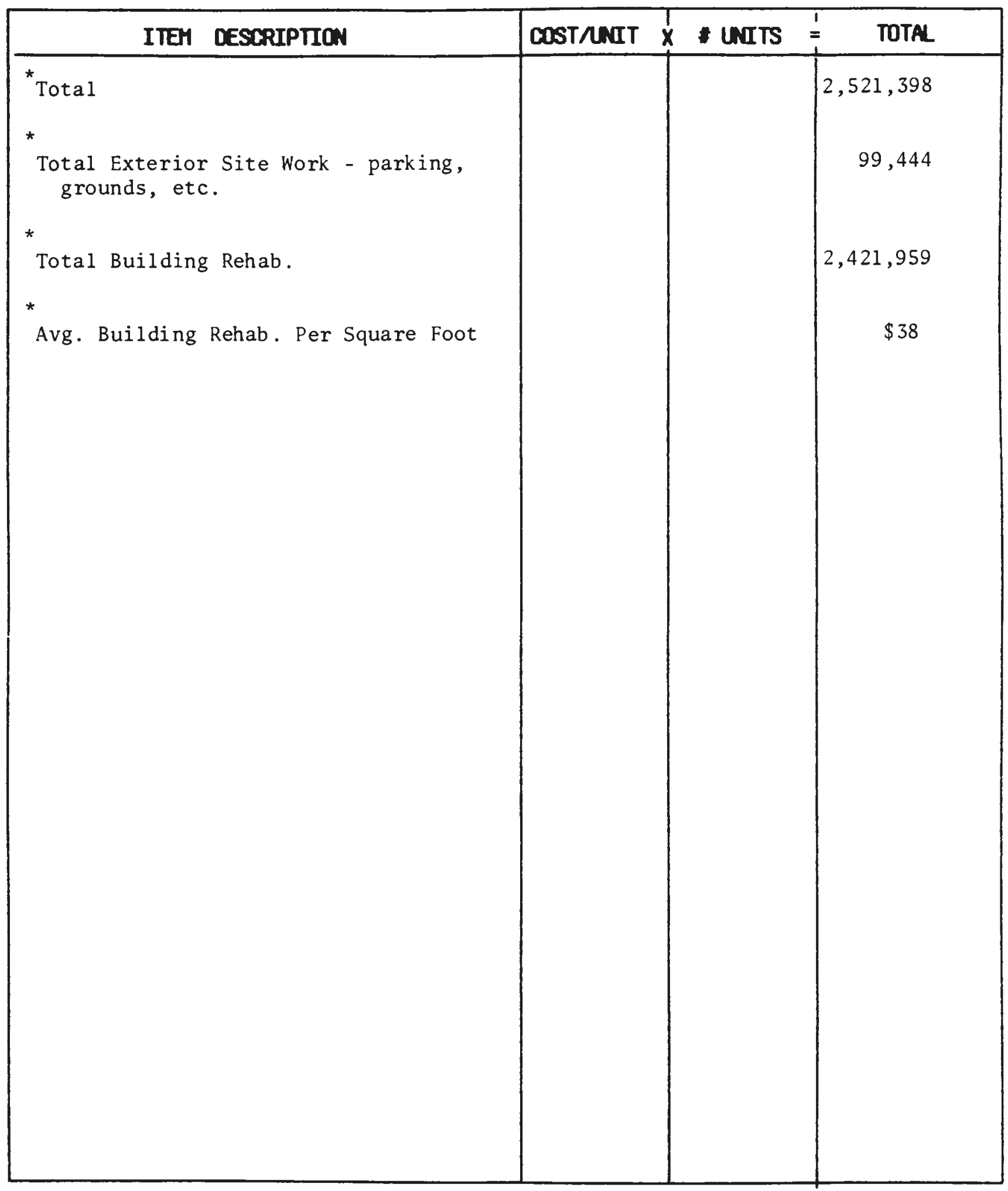

- SOURCE: HOME-TECH REHODELIMG ANO REMOVATION COST ESTDIATOR 1984. VO. 1. Field Manual. Henty Reynolos. Hown-Tech Publicetions, Bethesda, Maryland.1984. 


\section{FINANCING}

Construction financing would be required to build the project. This would be the only financing necessary if the entire project is to be sold as condominiums. If the office rental alternative is chosen, take out financing would be needed for the portion of the buildings which remains in the ownership of the developer. In this case the specified portion of the construction financing would roll over into a mortgage. The terms of both the construction and possible take out financing are described below.

\section{CONSTRUCTION FINANCING}

Equity Participation:

-Irrevocable letter of credit for $10-20 \%$ of the project which can be called on at any time (funds will be earning interest at this time) plus ownership of the building.

Length of the Loan:

-18 months to 2 years with a charge of one point to renew the loan (length will depend on the rate of condo sales.)

Fund ing :

-Costs are funded monthly as work is completed according to the hard cost (construction, materials, etc.) and soft $\cos t$ (marketing, legal fees, etc.) budgets.

-For the purpose of analysis the loan is assumed to be received in equal monthly installments over the period of construction (1 year).

Payback:

- Interest on the amount of funds advanced is paid monthly.

$-90 \%$ of each condominium sale is paid to the bank (the selling rate determines the length of the deal.)

Interest Rate:

-2 points over prime, (assume 14\% for analysis.)

Points:

-1.5 points upon initiation and 1 point to renew the loan.

*The bank may also require letters from residential mortgage lenders expressing willingness to grant mortgages for the condominiums within the project.

*There would be no pre-construction sale requirement, given the current market conditions in the area.

\section{TAKE OUT FINANCING}

If the office rental alternative is chosen, the portion of the project remaining in ownership would require a mortgage.

Term:

-30 years.

Loan/Value Ratio:

-.8 (the increase in value post construction would automatically make the loan less than $80 \%$ of the value. Consequently, no down payment would be required.)

Interest Rate:

-1 point over prime (assume $13 \%$ for analysis.) 


\section{B. Alternative Development Option - First Floor Offices}

The first floors of each buildings contain the least desirable space for residential use. The windows view primarily onto either the parking area or the ten foot retaining wall which surrounds the property on two sides. There is also a security problem (even if it may be only a perceived problem) associated with residing on the first floor. For these reasons one option which will be considered is creating luxury rental office units. These may be sold later as office condominiums after the neighborhood has gentrified more significantly. If the situation demands these units could also be converted to residential units.

SUITABILITY OF OFFICE USE

As discussed in Chapter II, the office market in the area appears yet untested. However, the two block proximity to Copley Place holds the potential for a prestigous address. There is also ample parking for the few number of offices suggested and easy access from many commercial and residential centers. No use variance would be required as many types of professional offices are permitted. The marketability of the offices could be tested as tenants are sought in the pre-construction phase.

\section{INVESTMENT TAX CREDIT}

Perhaps the largest benefit is that the creation of offices would allow the developer to take a $20 \%$ Investment Tax Credit on the Rehabilitation cost. The building is more than 40 years old which qualifies it for the tax credit, however, the use must be non-residential. Consequently, the ITC would only be for the portion of the building intended for offices. The rehabilitation costs would be comparable to condo development totaling $\$ 616,116$ for the first floors of both buildings (although the offices will not have full kitchens, they will have kitchenettes and other custom features which would make the condo rehab. price an adequate estimate). The $20 \%$ Investment Tax Credit on this amount would be $\$ 123,223$. This is significantly larger than the initial investment into the project (initial investment, rental segment, includes: purchase price, construction interest, points, $\$ 106,093$.)

\section{SIZE}

For the purpose of analysis, two sizes of offices are contemplated. The smaller offices would be large enough for approximately 3 rooms, one each for the professional, secretary/ receptionist and library/equipment. There would also be a bathroom and kitchenette. The larger offices would allow for additional rooms to accomodate more than one professional or extra examination rooms. However, during the pre-construction phase when tenants are being sought, the space may be cut up differently as individual needs demand.

NUMBER OF UNITS

A layout comparable to that for the residential units will be used for analysis. This yields 12 offices, three of the smaller type, and nine larger. Of the larger offices, two have poor views and seven have better views. As previously stated this may change according to the needs of potential tenants. The analysis remains reasonably valid regardless of how the space is cut up as the rent is calculated per square foot.

RENT

The suggested rent for the of fice units range from seven to eight dollars per square foot. This is 
just slightly less than prevailing rates for comparable space in Back Bay. The monthly rent for the small units would be $\$ 500$. There would be two distinctions of larger office groups. Those with the poorest view would start at $\$ 600$ per month, and those with the better view would be set at $\$ 700$ per month. The model assumes a $5 \%$ increase in rent annual1y. Parking space rental would be set at $\$ 50$ per month, slightly less expensive than the going rate in Back Bay. The model assumes an average of one space will be rented for each office and a $5 \%$ annual increase in rent.

\section{IQU IDAT ION}

As property values rise and the neighborhood gentrifies more significantly, the units can be sold as office condominiums. It is unlikely, given the current composition of the neighborhood, that these units would sell easily at the present time. Consequently, renting would allow the owner to carry the units until the property had sufficiently appreciated in value. Some amount of remodeling and capital improvements would be needed prior to sale. Ten percent of the selling price should be budgeted for this purpose.

\section{Additional Consideration - Decreased Down Payment Requirement for Condo- munium Purchasers}

Another option considered is the possibility of the developer buying down the initial equity requirement for condominium purchasers. The reason for this is that the market analysis showed a large percentage of potential buyers have the necessary income to meet mortgage payments but not the savings for the down payment. Therefore, reducing the initial equity requirement may greatly improve marketability.

However, from the developer's perspective, buying down the initial payment is effectively decreasing the sales price. Consequently, this alternative would have to be judged against the benefits of a potentially shorter selling period. Or, the possibility of increasing the purchase price in light of this favorable financing opportunity could be examined. This would not decrease the profit to the developer but may still provide an additional incentive to buyers. In other words, it may be worthwhile for condominium purchasers to pay more in the long run if they could invest less initially.

The project alternatives described in the preceeding chapter will be investigated and refined further as a result of the feasibility analysis which follows. 


\section{Chapter V}

\section{Financial Analysis}

The following chapter provides a financial feasibility analysis of the proposed project. The two basic development alternatives described in Chapter IV will be examined. The first utilizes both buildings for the creation of residential condominiums. The units are priced, sized and equipped according to information resulting from the market investigation. The second option is also composed primarily of condominiums. However, recognizing the decreased marketability of the ground floor, office rental units are proposed at this location in both buildings.

Three scenarios varying from most optimistic to "worst case" are detail ed for each development alternative. They differ in selling rate, price, lease up period, rent, and construction cost. The computer aided spread sheet analysis is used to test the sensitivity of these variables with regard to their effect on the financial success of the project. These findings will determine the best development option as well as its projected economic feasibility.

The contents of the chapter is presented in the following sequence:

1. At the onset, the general assumptions implicit in the spread sheet model are explained. This is intended to clarify the inputs and theories employed in the design of the model.

2. The main focus of the chapter provides a financial analysis of each development opportunity as presented in three varying scenarios. This exposes the vulnerable as pects of the project and illustrates the anticipated results if projected market conditions are not realized.

3. Following the analysis, the additional consideration of developer assisted residential mortgage arrangements is explored as it applies to the two proposed development plans.

4. Finally, the optimum development alternative will be recommended in accord with the results of the financial analysis. 


\section{A. Assumptions}

\author{
CONSTRUCTION FINANCING
}

The construction financing arrangements assumed for the project represent the terms of a typical loan for condominium development. The construction loan agreement is discussed fully in Chapter IV. However, it bears brief repeating here due to the many accompanying assumptions which are necessary to model the project.

Equity Participation:

Irrevocable letter of credit for $15 \%$ of project rehabilitation cost and ownership of the building.

Length of Loan:

2 years, renewable, the rate at which the units sell actually determines the length of the loan.

\section{Points :}

1.5 point upon initiation.

1 point to renew loan.

Funding :

Costs are funded monthly as work is completed. The model assumes that the loan is received in twelve equal installments over the course of the construction time - one year.

Interest Payments:

Interest is calculated only on the amount currently loaned out. The model calculates the interest owed quarterly al though it is actually paid monthly. (Interest rate $-14 \%$ ).

\section{Principal Payments:}

Payments of principal occur when condominiums are sold. As each unit is sold, $90 \%$ of the selling price must go to the bank as a principal payment. For the purpose of analysis the model calculates the sales rate and principal payments quarterly.

\section{TAKE OUT FINANCING}

Take out financing would be necessary only for the portion of the buildings which were developed as offices.

Term:

30 years.

Interest Rate:

$13 \%$.

Points :

1.5

TAXES

Tax Rate:

The investor is assumed to be taxed $50 \%$ at the federal level and $5.375 \%$ in the State of Massachusetts.

Investment Tax Credit:

An ITC equal to $20 \%$ of the rehabilitation cost is assumed for the office segment of the project. The buildings are eligible for this credit because they are more than 40 years old. Two conditions accompany the ITC - the amount of the credit must be deducted from the basis for depreciation purposes, and the straight line method of depreciation must be elected. The ITC is actually larger than the initial investment. Consequently, for the purpose of analysis, rather than deducting the ITC from the initial outlay, yielding a negative number and making it impossible to calculate internal rate of return, the ITC is viewed as income in the first 
year.

\section{Depreciation:}

As previously stated straight line depreciation must be used for the office segment because of the ITC. The model also assumes straight line depreciation for the condominiums. This method was chosen because of the greater ease in estimation and the short amount of time the units would be depreciated. The units may only be depreciated after the building is placed "in service", which would be when the construction is complete, and only until the time that they se11. Consequently, the model uses the amount of time that the units remain unsold to calculate the depreciation allowed.

\section{INITIAL INVESTMENT OITLAY}

The analysis model assumes that the initial investment for the rental segment is equal to that amount of the purchase price, construction loan interest, and points which is attributable to the office portion of the buildings .

The analysis model assumes that the initial investment for the condominium segment is equal to the purchase price (which also constitutes the equity participation necessary for the loan.). The construction loan interest and points are calculated in with the loan principle and other costs associated with the rehabilitation.

\section{DISCOUNT FACTOR}

The discount factor assumed within the model is $12.8 \%$, equal to the current interest rate for long term treasury bill rates.

\section{Expenses}

The office rental expenses were estimated using information from the Institute of Real Estate Management Income/Expense Analysis for Office, Apartment and Condominiums. The expenses are assumed to increase $2 \%$ annually.

RENT

The model assumes a $5 \%$ annual increase in rent.

\section{PARKING SPACES}

The mode 1 assumes that 1.17 parking space will be sold with each condominium. This indicates that there will be a demand for every space. The model also assumes that one space will be rented with each office. When the office units are sold the price will include one space per unit. 
B. Basic Development

\section{Alternative - Residential Condominiums Only}

The residential condominium alternative is presented and tested in three scenarios. These scenarios are summarized in the following table. Selling rate, price, and construction cost are varied in order to illustrate the resulting financial consequences. The lengthy selling time reflects the fact that there are a number of less

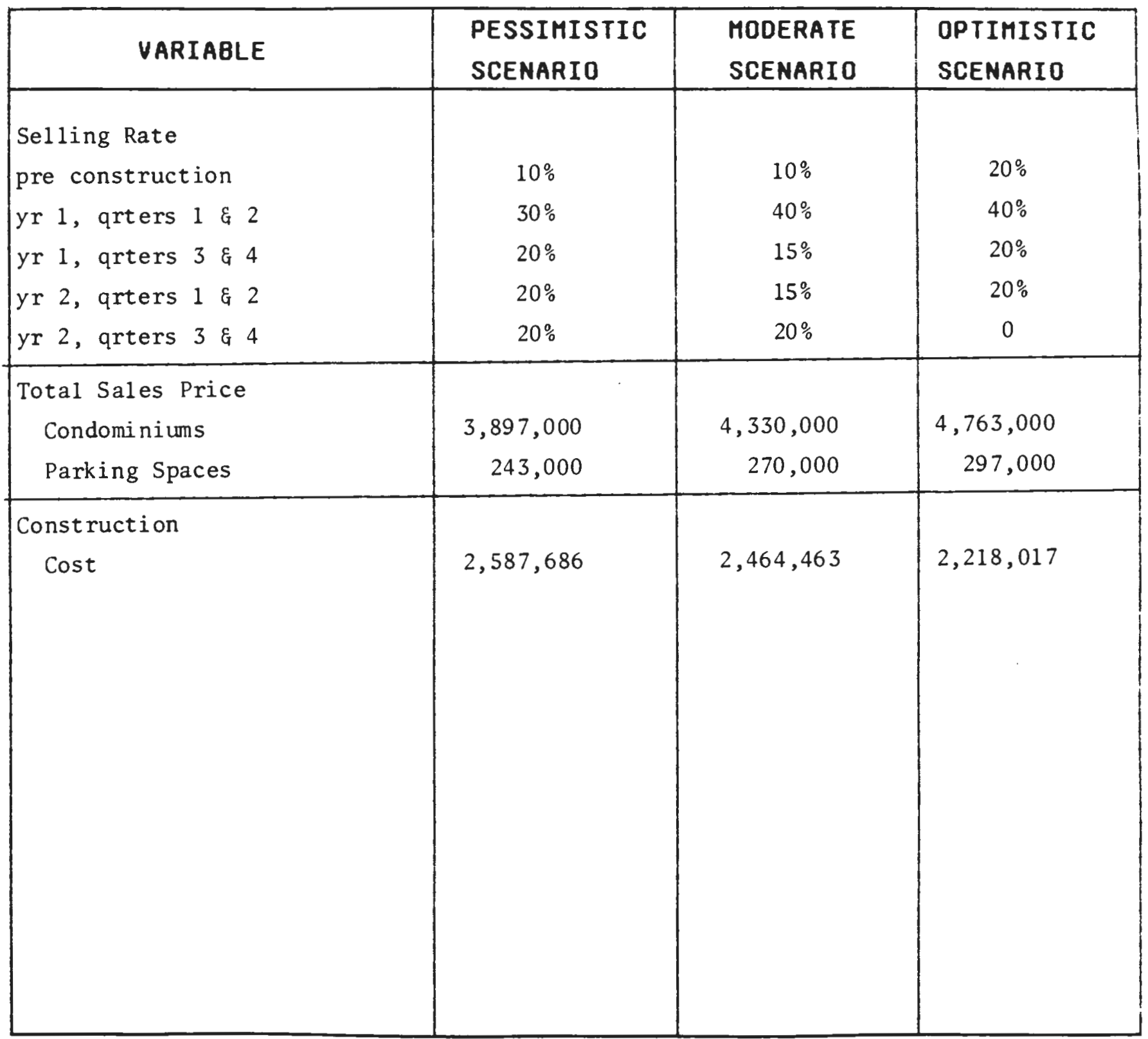

desirable first floor units. These units constitute approximately $25 \%$ of the entire project. 


\section{Findings: Basic Development Alternative - Condominiums Only}

The following figures and narrative illustrate the financial analysis of the basic development alternative under three varying scenarios. The table presents a summary of the key measures of success. These indicators are interpreted and explained in the following text. The complete detailed financial spread sheets are then presented at the conclusion of the section.

It is clear in all three scenarios that the value added to the property through condominium development is substantial. Even though the estimated gross selling price, varies close to one million dollars from the worst to best case projections, the return remains high. Under the optimistic scenario, the total discounted return is $\$ 1,873,280$. This assumes that the condominiums will sell within a year and a half after the building is placed in service and that the selling prices will be slightly higher than the current average for the neighborhood. However, even if the units take two full years to sell and command prices ten percent below the current area average, the project yields a discounted return of $\$ 843,215$. The moderate scenario, most closely reflecting present market conditions shows a discounted return of $\$ 1,262,462$.

The Net Present Value of the project is positive under all these scenarios. This indicates that the investor is receiving greater than his required rate of return. The model assumes $12.8 \%$ as the required rate. (This is equal to the current long term treasury bill rate.) It is clear at a glance that the project is yielding a much higher precent. The net present value for the moderate scenario is $\$ 997,462$. Even under the pessimistic scenario, the net present value is over half of a million dollars. This is, of course, because all the units are being sold

\section{SUMMARY OF KEY INDICATORS}

\begin{tabular}{|l|c|c|c|}
\hline & $\begin{array}{c}\text { PESSIMISTIC } \\
\text { SCENARIO }\end{array}$ & $\begin{array}{c}\text { MODERATE } \\
\text { SCENARIO }\end{array}$ & $\begin{array}{c}\text { OPTIMISTIC } \\
\text { SCENARIO }\end{array}$ \\
\hline $\begin{array}{l}\text { Total Return After Taxes and } \\
\text { Brokerage Fees }\end{array}$ & $1,001,198$ & $1,479,252$ & $2,114,489$ \\
Total Discounted Return At & 843,215 & $1,262,462$ & $1,873,280$ \\
NPV of Profit & 578,215 & 997,462 & $1,608,280$ \\
\%eturn on Initial Investment & $378 \%$ & $558 \%$ & $798 \%$ \\
At $\begin{array}{l}\text { Internal Rate of Return } \\
\text { Investment Value }\end{array}$ & $3,430,901$ & $3,726,925$ & $4,091,292$ \\
& & & \\
\end{tabular}


within a short period of time (2 yrs even in the pessimistic scenario) and the discount factor has less of an impact.

While the positive net precent value indicates the rate of return is greater than $12.8 \%$ (the discount factor employed), the actual rate is identified as the internal rate of return. The IRR calculated for the three scenarios is extremely high. As previously noted, this is because the units are developed and sold all in a short period. The discount factor has less of an impact because the return on the investment is received so quickly. The pessimistic and moderate scenarios show an internal rate of return of $181 \%$ and $402 \%$ respective1y. The IRR for the optimistic is actually infinity. This is because the "best case" scenario assumes that $20 \%$ of the units will be sold during the pre-construction stage. Under this scenario, more proceeds from sales are received than funds are axpended in the start up year. Consequently, regardless of the discount factor employed the net present value will never equal zero.

The return on the initial equity investment projected for all three scenarios is tremendous. Again, assuming the investor's required rate of return is $12.8 \%$, the return on initial investment is $378 \%$ under the pessimistic scenario, $558 \%$ under the moderate scenario and $798 \%$ under the optimistic scenario. This illustrates the project's overwhelming potential for profit compared to the initial equity required.

The final measure of success, investment value, indicates the amount the investor would be justified in paying for acquisition and renovation costs, according to the selling schedule of the units. According to the selling rate projected in the moderate scenario, the investor would be justified in paying $\$ 3,726,925$. However the actual cost is only $\$ 2,729,463$. Cons equently, the project represents a very good deal as the property is substantially under-priced. The optimistic scenario represents the project as even a better deal with an investment value of $\$ 4,091,297$ compared to a cost of $\$ 2,483,017$. The investment value under the pessimistic scenario is also far in excess of the actual acquistion and renovation price, $\$ 3,430,901$ compared to $\$ 2,582,686$.

From all indications, under all three scenarios, the project appears a sound investment with an extremely high potential for return. Only one other factor need be considered, particularly when comparing the basic development alternative with the mixed use office alternative. That is, the risk involved with the sale of the first floor units. Although the pessimistic scenario assumes a lowered price and long selling period for these units, there may be an outside chance that they would not sell in two years or only at a very unreasonable price. If the units did not sell the total discounted return would be reduced from $\$ 843,215$ to $\$ 116,672$ under the pessimistic scenario. The net present value in this case would actually fall below zero at $-\$ 148,328$ making the project a losing investment. The uncertain sales appeal of these first floor units should be considered when evaluating the two development alternatives. 


\section{Residential Condominiums Only \\ PESSIMISTIC SCEMARIO}

2

3

4

Purchase Price

Est. Land Valu

Rehtilitetion cost-Total

Acovisition Price 6 Renov

Total floor Ares (square feot)

Const Loen (hard 6 soft costs)

Equity Participation

Pay Back

Construct. Loan Am Int Rate

Construct. Loan Int Rate/ionth .011666667

.015

.01

1

.1

Points

Points to Renew Loan

Construction Tine

Construction Loen Tern

Aprox. Funding Schedule/Month

Est. Pre Comp. Condo Sales

Est. Pre Conp Pkg Space Sales

Ho fund. w/90: pre cons sales

Int Construct Loan (1st 6nos)

Int Construct Loan(2nd 6 nos)

TOTAL CONST LOAN IMT SU YR

Renain Prin at End Start Up

Renain PIin Con Loan(162 aru)

Renain Prin Con Loan(364 grtr)

.3 Condo Sales YI 1 (1st 6 2nd art

Pko Space Sales Yr 1 (162 art

.2 Condo Sales $Y_{\mathrm{r}}$ 1(3rd 6 4th art

Pkg Space Sales YI 1 (364 qrtr)

.2 Condo Sales $Y_{I} 2$ (1 62 qrtr)

Pko Space Sales Yr 2 (364 qrtr)

.2 Condo Sales YI 2 ( 3 \& 4 grtr)

Pko Space Sales YI 2(364 grt

Mo Payback w/903 C Sales(162qr

Ho Paylack w/908 C Sales(364q

Int Cons Loon(15t arter)

Int Cons Loen(2nd arter)

Int Cons Losn(3rd arter)

Int Cons Loan(4th qrtar)

TOTAL COUST LOAN INT

Prop Val-Condo Seg(sales price 3,897,000

Pko Space Val-Condo Seo(sales 243,000

Acquis-Renov. Cost-Condo Seg 2,852.686

Est Land Value

100,000

Initial Investrent-Condo Seq

Constent for Acc Deprec.

Incone Tax Rate

Econ Life of Bldg

.128

265,000

100,000

2.852 .696

64,500

2.587 .686

BLDG.

38.815

YI-Renew

389.700

24, 300

186.413

(5.671

169.636

72,900

48,600

4.600

48.600

Inyestor Rea, ROI

265.000

1.75

15

.128
FUWDE AS WOOK IS COIPLETED

LETTER OF CEEOIT

IMTEREST ON FUmED LOA PORTIOA + 904 COMDO SALES

$1,184,766$

$1,184,766$

483.306

483,306

1.169 .100

$-218154$

(1)

$-701460$

0

779,400

779,400

779,400

175.365

116,910

66,018

66,018

47.605

47.605

45.559

45.559

33.283

33.283

192.464

116.910

116.910

8.732

8.732

$(3.544)$

$(15,819)$

$(28,095)$

0

8,732

Mo. of thits

Initial Equity

46

265.000

COHDOIIMIU \& PKG SPACE SALES Estinated Gross Sale Price

414,000

2.070 .000

1.656 .000 


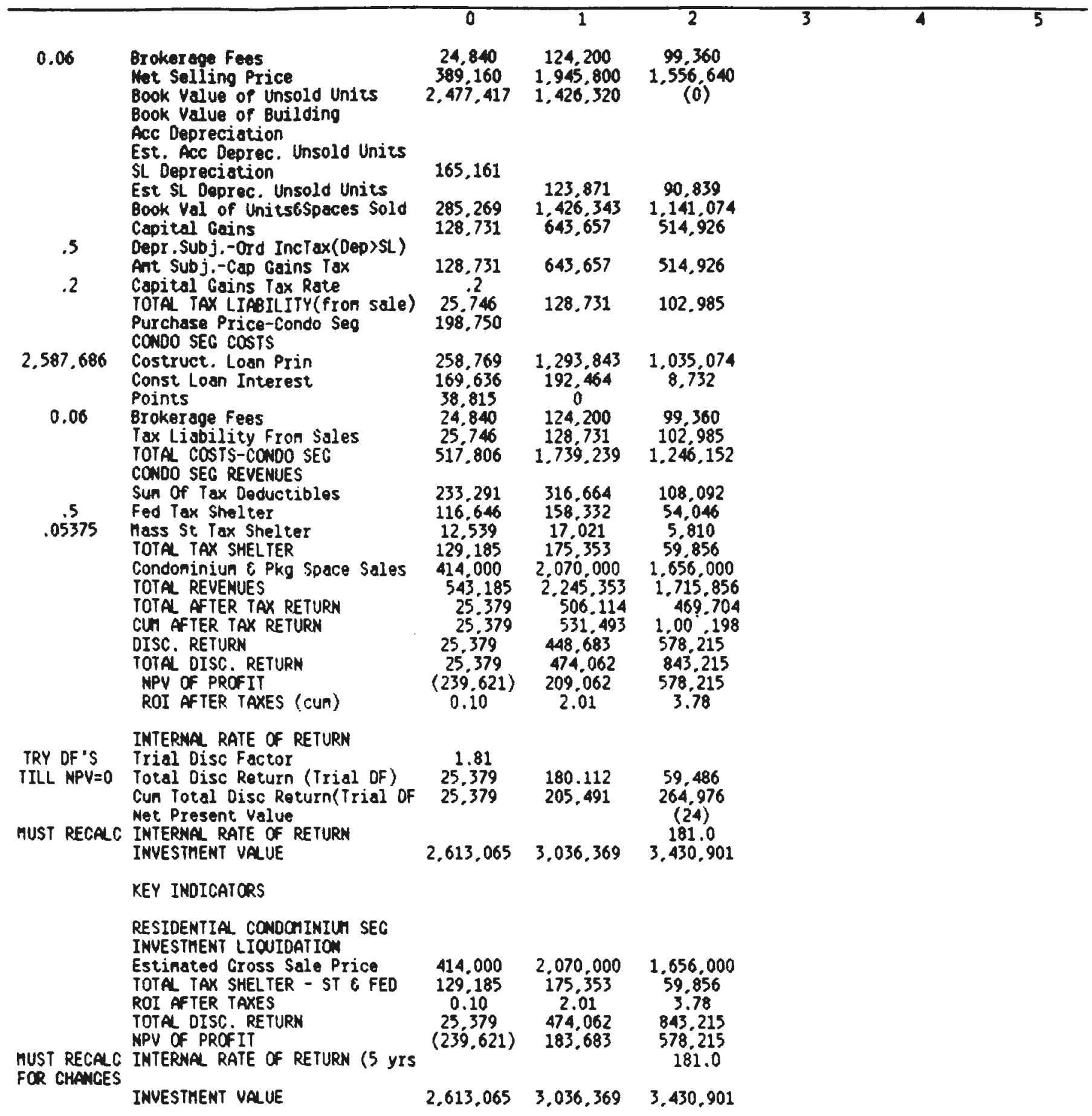




\section{Residential Condominiums Only MODERATE SCENARIO}

ASSITPTIONS YEAR

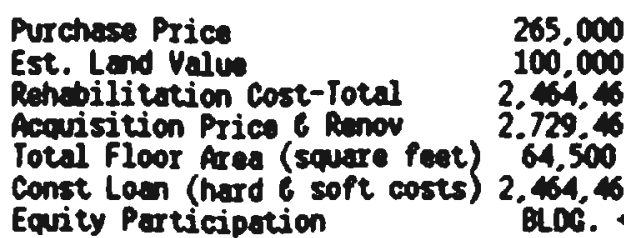

265.000

100,000

2.404 .453

2.729 .463

Poy Beak

construct. Loan inn Int kate

$2,464,4.53$

QDOR. -

FUMED AS WOK IS COHPLETED

Construpt. Loen Int Ratemonth .01166467

.015 Points

.01 Points to Renow Loen

1 Construction Tin

Construction Loen Torn

MONTHLY INTEREST ON FUMED LOAN PORTION - 908 CONDO SALES

Aprox. Funding schedulemonth

1 Est. Pre Conp. Condo Sales

Est. Pre Comp Pko Space Sales

Ho Fund. w/908 pre cons sales

Int Construct Loen (1st 6nos)

Ine Construet Loan (2nd 6 mos)

TOTAL coust LOAN INT SU VR

36.967

Renain Prin at End Start Up Yr 2,074,763

Renain Prin Con Losn(162 qrtr)

Renain Prin Con Loen(364 qrtr)

.4 Condo Sales Yr 1 (1st 6 2nd qrt

Pho space Salos Yr 1 (162 qrtr

.15 Condo Sales YI 1(3rd t th art

15 Pkg Space Sales $Y_{T} 1$ (364 qutr)

.15 Condo Sales Yr 2 (1 62 qrtr)

.2 Condo Sales $\mathrm{Yr}_{2}$ ( 3 \& $4 \mathrm{qu}$ )

Pkg Space Sales Yr 2(364 qrur)
Ho Payback w/90e C Sales (162qr

Ho Paroak w/90: C Sales(364)

108,000

$24 \mathrm{r}$-Rene:

205,372

433.000

27,000

172.897

42, 360

114976

114.976

$, 074,763$

515.96

515,963

$(68,587)$

0

0
-779400
0

$1,732,000$

40.500

649,500

40,500

54.000

649,500

866.000

$259.800 \quad 97,425$

$97.425 \quad 129.900$

$54.431 \quad(6,820)$

Int Cons Loen(1st qrter)

54.431

27.152

27.152

45.338

45.338

35,108

35,108

Int Cons Loen (4th prter)

TOTAL COUST LOAM INT

Prop Val-Condo Seg(sales price 4,330,000

162,028

Pkg Spece Val-Condo Ser (sales

270,000

Acquis+Renov. Cost-Condo Seg 2,729,463

Est Land Value

100,000

Initial Investnent-Condo Seg 265,000

Constert for Acc Deprec. 1.75

Incorr Tax Rote

0.50

Econ Life of Blda

15

Imvestor Req. ROI

.128

Mo. of Units

46

Initial Equity

265,000

COMONIMIU C PKC SPACE SALES Estinated Gross Sale Price

0.06

Brokerage Fees

460.000

2.530 .000

1.610 .000

27.600

151.800

96.600 


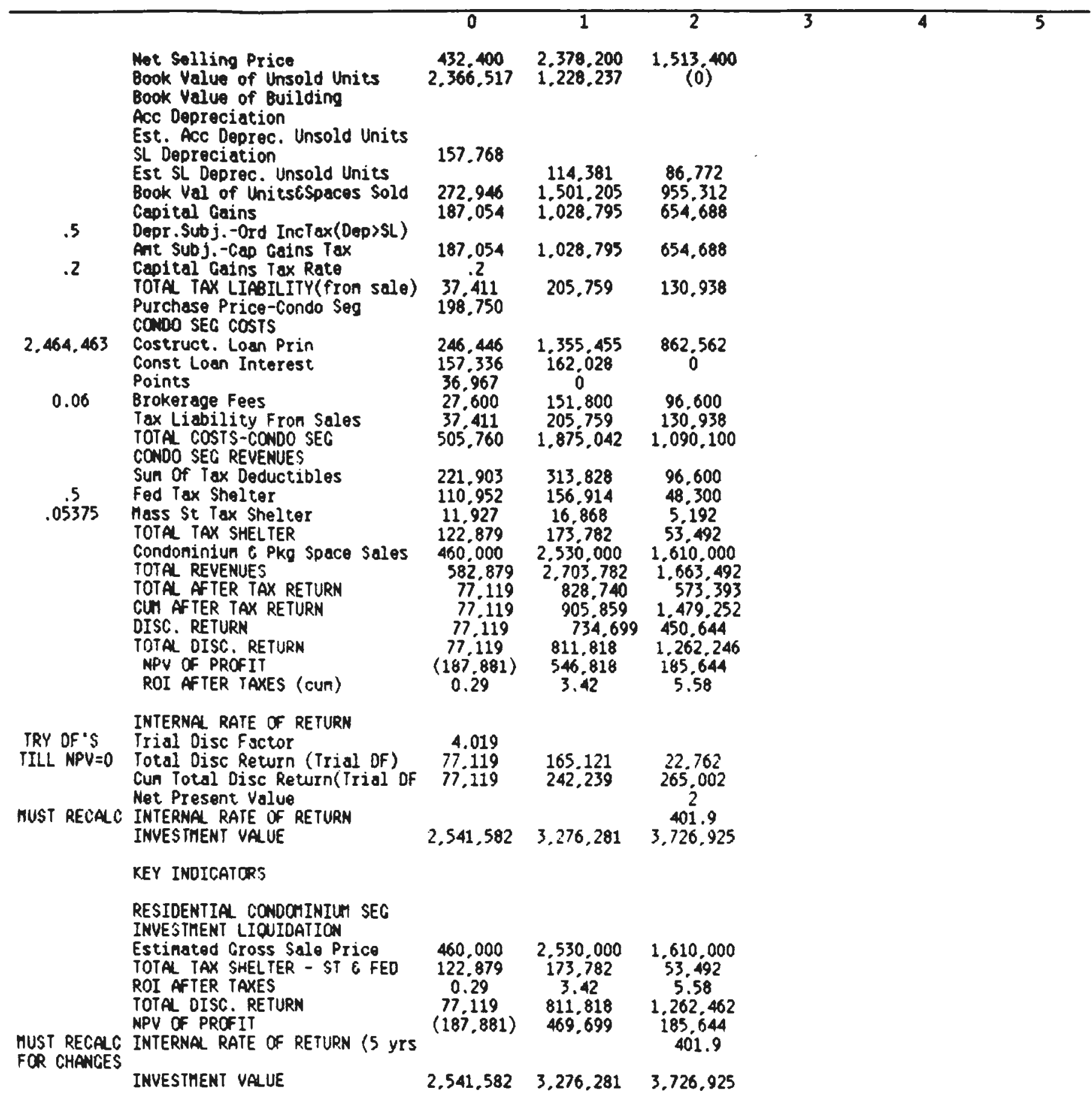




\section{Residential Condominiums Only \\ OPTIMISTIC SCENARIO}

\begin{tabular}{llllllll}
\hline ASSLAPTIONS YEAR & 0 & 1 & 2 & 3 & 4 & 5
\end{tabular}

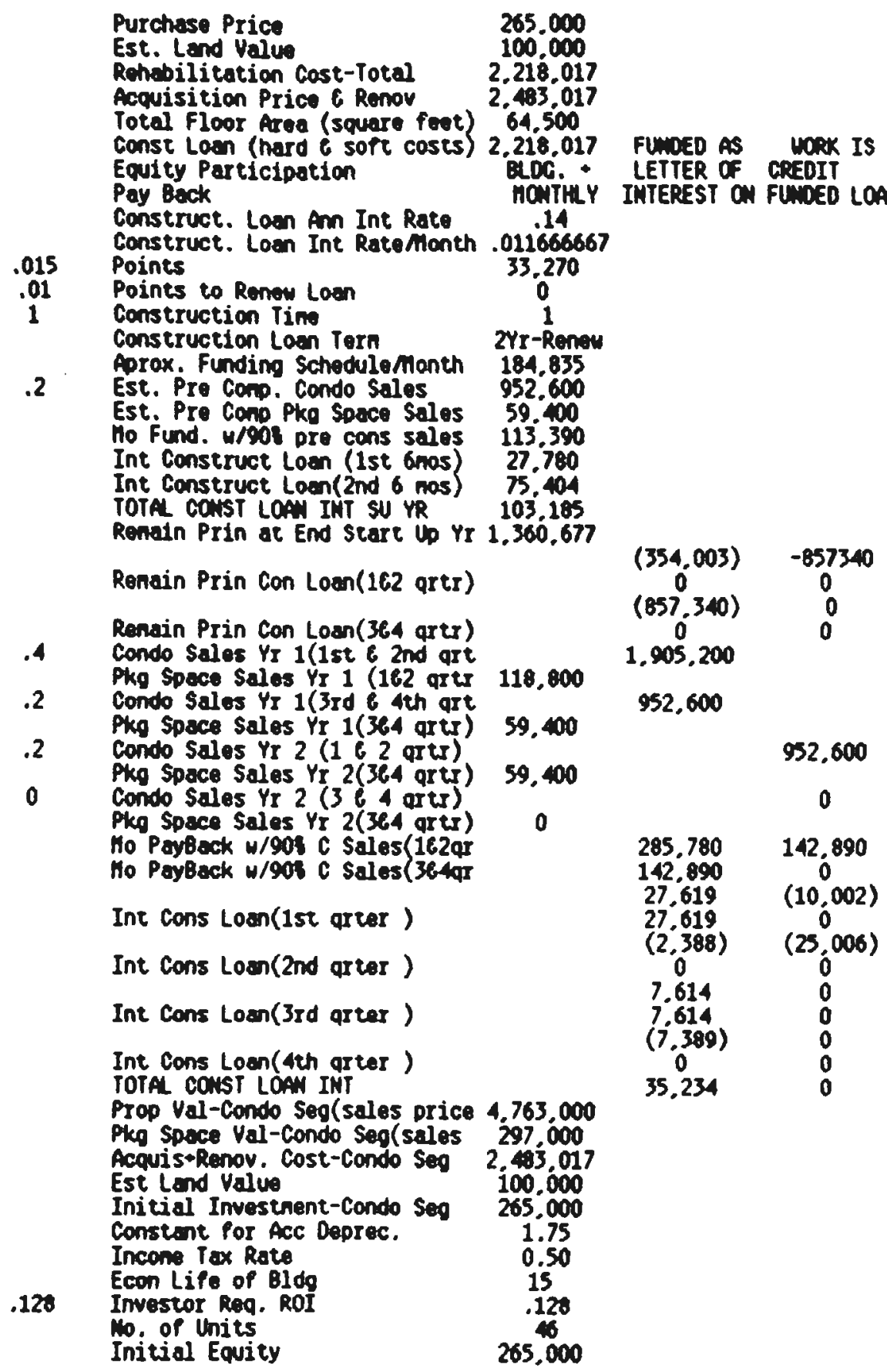




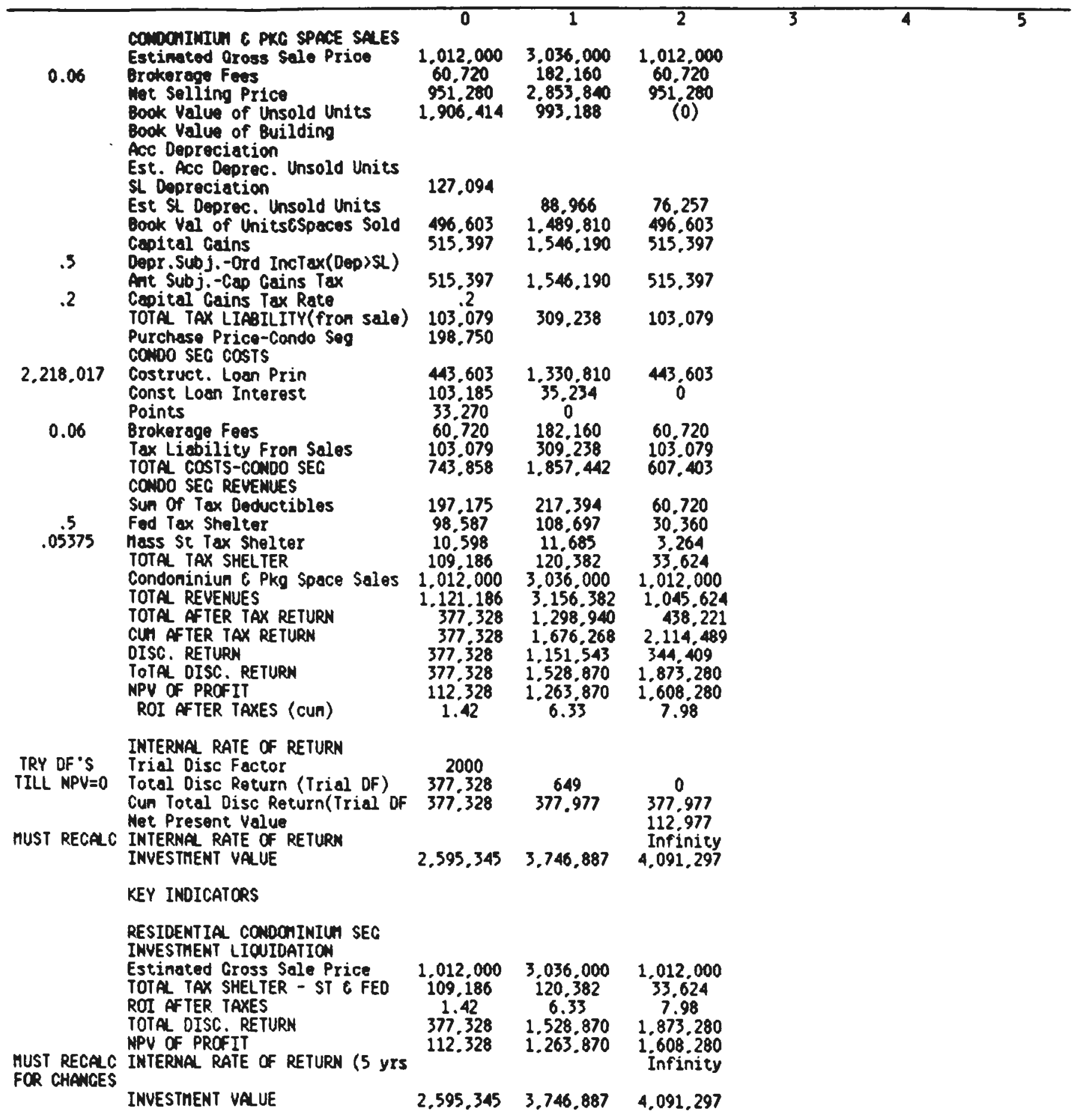




\section{Alternative Development resulting financial consequences. Option - Condominiums With First Floor Offices}

Similar to the basic development alternative, the first floor office alternative is presented and tested in three scenarios. These scenarios are summarized in the following table. Selling rate, price, rent, lease up period, vacancy rate, construction cost and office liquidation price are varied in order to illustrate the

\begin{tabular}{|c|c|c|c|}
\hline VARIABLE & $\begin{array}{l}\text { PESSIMISTIC } \\
\text { SCENARIO }\end{array}$ & $\begin{array}{l}\text { MODERATE } \\
\text { SCENARIO } \\
\end{array}$ & $\begin{array}{l}\text { OPTIMISTIC } \\
\text { SCENARIO }\end{array}$ \\
\hline $\begin{array}{l}\text { Selling Rate } \\
\text { pre construction } \\
\text { yr } 1 \text {, qrters } 1 \& \text { \& } 2 \\
\text { yr } 1 \text {, qrters } 3 \& 4 \\
\text { yr } 2 \text {, qrters } 1 \& 82 \\
\text { yr } 2 \text {, qrters } 3 \& 4\end{array}$ & $\begin{array}{l}10 \% \\
30 \% \\
30 \% \\
20 \% \\
10 \%\end{array}$ & $\begin{array}{r}10 \% \\
40 \% \\
40 \% \\
10 \% \\
5 \%\end{array}$ & $\begin{array}{r}20 \% \\
40 \% \\
40 \% \\
0 \% \\
0 \%\end{array}$ \\
\hline $\begin{array}{l}\text { Total Sales Price } \\
\text { Condominiums } \\
\text { Parking Spaces }\end{array}$ & $\begin{array}{r}2,947,000 \\
189,000\end{array}$ & $\begin{array}{r}3,330,000 \\
210,000\end{array}$ & $\begin{array}{r}3,663,000 \\
231,000\end{array}$ \\
\hline $\begin{array}{l}\text { Total Rent Offices and } \\
\text { Parking Spaces }\end{array}$ & $\begin{array}{l}97,200 \\
\text { increasing } 5 \% \\
\text { annual } 1 y\end{array}$ & $\begin{array}{l}97,200 \\
\text { increasing } 5 \% \\
\text { annually }\end{array}$ & $\begin{array}{l}106,920 \\
\text { increasing } 5 \% \\
\text { annualiy }\end{array}$ \\
\hline $\begin{array}{l}\text { Lease up Period/ } \\
\text { Vacancy Rate }\end{array}$ & $\begin{array}{rrr}\operatorname{yr} & 1 & 30 \% \\
\operatorname{yr} & 1 & 6 \%\end{array}$ & $5 \%$ & $3 \%$ \\
\hline Construction Cost & $2,587,686$ & $2,464,463$ & $2,218,017$ \\
\hline $\begin{array}{l}\text { Selling Price } \\
\text { of office Condominiums } \\
\text { yr } 1 \\
\text { yr } 2 \\
\text { yr } 3 \\
\text { yr } 4 \\
\text { yr } 5\end{array}$ & $\begin{array}{l}\text { no appreciation } \\
\begin{array}{l}1,000,000 \\
1,000,000 \\
1,000,000 \\
1,000,000 \\
1,000,000\end{array}\end{array}$ & $\begin{array}{r}2 \% \text { anrual } \\
\text { appreciation } \\
1,020,000 \\
1,040,000 \\
1,061,208 \\
1,082,432 \\
1,104,081\end{array}$ & $\begin{array}{l}3 \% \text { annual } \\
\text { appreciation } \\
1,030,000 \\
1,060,900 \\
1,092,727 \\
1,125,509 \\
1,159,274\end{array}$ \\
\hline
\end{tabular}




\section{E Findings: Alternative Option - Condominiums With First Floor Offices}

The following figures and narrative illustrate the financial analysis of the mixed use alternative under the three varying scenarios. The five tables present a summary of the key measures of success. The first table addresses the residential segment of the project, the next three refer to the office segment and the final table deals with the entire project. These indicators are interpreted and explained in the following text. The analysis will focus first on the residential condominium segment alone, then on the office segment, and finally on the entire project. The complete detailed financial spread sheets are then presented at the conclusion of the section.

\section{RESIDENT IAL CONDOMINIUM SEGMENT}

Just as in the evaluation of the preceeding alternative, it is clear in all three scenarios that the value added to the property through condominium development is substantial. Even though the estimated gross selling price varies close to a million dollars from the worst to best case projections, the return remains extremely high. Under the optimistic scenario the total discounted return for just the condominium segment of the project is $\$ 1,483,469$. It's important to compare this figure with the return projected under the optimistic scenario for the "condominiums only" alternative. Although the mixed use development offers 12 fewer units for sale, the return is only $\$ 400,000$ less (much less than the actual cost of the units). This vividly illustrates the advantages of fewer units that sell quickly over a large number of units with a longer selling period. The total discounted return under the other two scenarios is even closer to the all residential alternative.

\section{SUMMARY OF KEY INDICATORS RESIDENTIAL CONDOMINIUM SEGMENT}

\begin{tabular}{|l|c|c|c|}
\hline & $\begin{array}{c}\text { PESSIMISTIC } \\
\text { SCENARIO }\end{array}$ & $\begin{array}{c}\text { MODERATE } \\
\text { SCENARIO }\end{array}$ & $\begin{array}{c}\text { OPTIMISTIC } \\
\text { SCENARIO }\end{array}$ \\
\hline $\begin{array}{l}\text { Total Return After Taxes and } \\
\text { Brokerage Fees }\end{array}$ & 738,556 & $1,171,692$ & $1,637,501$ \\
Total Discounted Return At & 628,491 & $1,030,689$ & $1,483,469$ \\
NPV of Profit & 429,741 & 831,939 & $1,284,719$ \\
$\%$ Return on Initial Investment & $372 \%$ & $590 \%$ & $824 \%$ \\
At & $186 \%$ & $558 \%$ & infinity \\
Internal Rate of Return & $2,569,255$ & $2,879,036$ & $3,146,982$ \\
& & & \\
\hline
\end{tabular}


project is positive in all three scenarios. This indicates the investor is receiving greater than his required rate of return. Again the NPV of the optimistic scenario $(\$ 1,284,719)$ is relatively close to the NPV of the "condominiums only" alternative. This indicator under the pessimistic $(\$ 429,741)$ and moderate $(\$ 831,839)$ scenarios is just slightly less than the preceeding alternative.

While the positive NPV's indicate the rate of return is higher than $12.8 \%$, the internal rate of return identifies the actual rate. The IRR is very high in all three scenarios. As noted in the preceeding alternative this is because the condominiums are sold in a short period of time. The optimistic scenario exhibits an IRR of infinity because the preconstruction sales are greater than the initial investment. The IRR for the pessimistic and optimistic scenarios are $186 \%$ and $558 \%$ respectively.

The relatively small equity participation required makes the return on investment extremely high. The optimistic scenario shows an ROI of $824 \%$. The moderate scenario exhibits an ROI of $590 \%$ and even though the pessimistic alternative yields a much lower return, the initial investment is more than tripled.

The final measure of success, investment value, indicates that, according to the selling rate of the moderate scenario, the investor would be justified in paying $\$ 2,879,036$ for acquisition and renovation. Since the actual cost is only $\$ 2,047,097$, the investor is receiving a good deal (more than his required rate of return). The optimistic scenario illustrates the project as even a better deal with an investment value of $\$ 3,146,982$ compared to the actual cost of $\$ 1,862,263$. And, even under the pessimistic scenario the investment value is much greater than the actual cost. 
OFFICE SEGMENT

Operation Phase

The main financial benefit of the property during the first five years is its ability to shelter other income. This is evidenced by the negative before tax cash flows and positive after tax cash flows. Tax shelter ability decreases over the life of the project reflecting the ratio of interest to principal. The total tax shelter (federal and state) under the moderate scenario ranges from $\$ 49,954$ to $\$ 34,899$ over the five year span.

The after tax cash flow is particularly high in the first year due to the project:s eligibility for an Investment Tax Credit. This is one of the most attractive features associated with the office segment. This allows the investor to receive a tax credit equal to $20 \%$ of the rehabilitation cost. The building is eligible because it is more than 40 years old. However, only the office segment may receive an ITC, residential uses are excluded. To use the ITC, the straight line method of depreciation must be employed and the amount of the credit must be deducted from the depreciable basis. For the purpose of analysis, the ITC is viewed as income in the first year, $\$ 123,223$ under the moderate scenario. Another way to view the ITC is in relation to the initial investment. In this case, the ITC reduces the initial investment from $\$ 106,093$. to $-\$ 17,130$, strikingly portraying its advantages.

Due to the ITC, the return on investment is significantly high in the first year of all three scenarios, well over $100 \%$ under the moderate and optimistic, and $91 \%$ under the pessimistic scenario. Years two through five exhibit a much lower return on investment, ranging from $2 \%$ to $5 \%$ under the worst case scenario and from $11 \%$ to $17 \%$ under the best conditions.

This pattern is paralleled in the discounted after tax cash flows. The positive discounted ATCF's in all years of all three scenarios indicates that the project is never yielding less than the required rate of return. However, this indicator is large in the first year and very small in the following years. Under the moderate scenario, after the cash flows have been discounted at $12.8 \%$, the excess in years two through five is only between $\$ 2,000$ and $\$ 4,000$. This illustrates that the project is yielding at just slightly over the required rate of return in these years.

The internal rate of return takes into account the after tax cash flows for all five years as well as the initial investment. The pessimistic scenario exhibits an operation phase IRR of only $2 \%$. The moderate and optimistic scenarios show a much greater potential with IRR's of $32 \%$ and $59 \%$ respectively.

Termination Phase

The purpose of retaining ownership of the office segment of the project is not only to utilize the tax shelter, but also to wait until property values have appreciated significantly and the units would bring a higher selling price. Consequently, examining the termination phase is critical to evaluation of the investment. The three scenarios approximate varying market conditions at the time of sale.

In general, the model assumes that $5 \%$ of the property value will be devoted to renovation of the units before their sale as office condominiums. The base price in year one for all the units is $\$ 1,000,000$. This includes a parking 
SUMMARY OF KEY INDICATORS: OFFICE SEGHENT - PESSIMISTIC SCENARIO

\begin{tabular}{|c|c|c|c|c|c|}
\hline OPERATION PHASE & YEAR 1 & YEAR 2 & YEAR 3 & YEAR 4 & YEAR 5 \\
\hline \begin{tabular}{|l|} 
Before Tax Cash Flow \\
Return on Investment BT \\
Total Tax Shelter (Fed. \\
\& State) \\
After Tax Cash Flow \\
Disc. After Tax Cash \\
Flow \\
Return on Investment AT \\
Total Benefit (ATCF \& \\
Equity) \\
Internal Rate of Return
\end{tabular} & $\begin{array}{c}(71,612) \\
(.52) \\
67,021 \\
124,793 \\
110,632 \\
91 \% \\
112,379\end{array}$ & $\begin{array}{c}(43,800) \\
(.32) \\
46,121 \\
2,321 \\
1,824 \\
2 \% \\
116,176\end{array}$ & $\begin{array}{c}(40,081) \\
(.29) \\
43,793 \\
3,712 \\
2,587 \\
3 \% \\
121,220\end{array}$ & $\begin{array}{c}(36,144) \\
(.26) \\
41,168 \\
\\
5,025 \\
3,104 \\
4 \% \\
127,585\end{array}$ & $\begin{array}{c}(31,977) \\
(.23) \\
38,181 \\
6,205 \\
3,398 \\
5 \% \\
135,470 \\
2.29 \%\end{array}$ \\
\hline TERMINATION PHASE & YEAR 1 & YEAR 2 & YEAR 3 & YEAR 4 & YEAR 5 \\
\hline $\begin{array}{l}\text { Discounted Net to Sel- } \\
\text { ler } \\
\text { Total Discounted Return } \\
\text { AT } \\
\text { NPV of Profit } \\
\text { Internal Rate of Return } \\
\text { Investment Value }\end{array}$ & $\begin{array}{l}197,290 \\
307,105 \\
171,550 \\
882,776\end{array}$ & $\begin{array}{l}171,339 \\
282,714 \\
147,159 \\
858,385\end{array}$ & $\begin{array}{l}150,437 \\
264,149 \\
128,595 \\
839,821\end{array}$ & $\begin{array}{l}134,070 \\
250,654 \\
115,099 \\
826,325\end{array}$ & $\begin{array}{r}121,919 \\
241,683 \\
106,129 \\
39.49 \% \\
817,355\end{array}$ \\
\hline
\end{tabular}

SUMMARY OF KEY INDICATORS: OFFICE SEGMENT MODERATE SCENARIO

\begin{tabular}{|c|c|c|c|c|c|}
\hline OPERATION PHASE & YEAR 1 & YEAR 2 & YEAR 3 & YEAR 4 & YEAR 5 \\
\hline $\begin{array}{l}\text { Before Tax Cash Flow } \\
\text { Return on Investment BT } \\
\text { Total Tax Shelter (Fed. } \\
\text { \& State) } \\
\text { After Tax Cash Flow } \\
\text { Disc. After Tax Cash } \\
\text { Flow } \\
\text { Return on Investment AT } \\
\text { Total Benefit (ATCF \& } \\
\text { Equity) } \\
\text { Internal Rate of Return }\end{array}$ & $\begin{array}{l}(43,224) \\
(.41) \\
49,954 \\
129,953 \\
115,207 \\
122 \% \\
115,870\end{array}$ & $\begin{array}{c}(39,712) \\
(.37) \\
42,772 \\
\\
3,060 \\
2,405 \\
3 \% \\
121,154\end{array}$ & $\begin{array}{c}(35,993) \\
(.34) \\
40,457 \\
\\
4,464 \\
3,110 \\
4 \% \\
126,605\end{array}$ & $\begin{array}{c}(32,056) \\
(.30) \\
37,853 \\
\\
5,798 \\
3,581 \\
5 \% \\
133,292\end{array}$ & $\begin{array}{l}(27,889) \\
(.26) \\
34,899 \\
7,010 \\
3,839 \\
7 \% \\
141,404 \\
31 \%\end{array}$ \\
\hline TERMINATION PHASE & YEAR 1 & YEAR 2 & YEAR 3 & YEAR 4 & YEAR 5 \\
\hline $\begin{array}{l}\text { Discounted Net to Sel- } \\
\text { ler } \\
\text { Total Discounted Return } \\
\text { AT } \\
\text { NPV of Profit } \\
\text { Internal Rate of Return } \\
\text { Investment Value }\end{array}$ & $\begin{array}{l}230,137 \\
345,344 \\
239,251 \\
895,209\end{array}$ & $\begin{array}{l}212,718 \\
330,329 \\
224,236 \\
880,195\end{array}$ & $\begin{array}{l}198,133 \\
318,855 \\
212,762 \\
868,721\end{array}$ & $\begin{array}{l}186,232 \\
310,535 \\
204,442 \\
860,400\end{array}$ & $\begin{array}{r}176,996 \\
305,137 \\
199,044 \\
66.95 \% \\
855,003\end{array}$ \\
\hline
\end{tabular}


SUMMARY OF KEY INDICATORS: OFFICE SEGMENT - OPTIMISTIC SCENARIO

\begin{tabular}{|c|c|c|c|c|c|}
\hline OPERATION PHASE & YEAR 1 & YEAR 2 & YEAR 3 & YEAR 4 & YEAR 5 \\
\hline $\begin{array}{l}\text { Before Tax Cash Flow } \\
\text { Return on Investment BT } \\
\text { Total Tax Shelter (Fed. } \\
\text { \& State) } \\
\text { After Tax Cash Flow } \\
\text { Disc. After Tax Cash } \\
\text { Flow } \\
\text { Return on Investment AT } \\
\text { Total Benefit (ATCF \& } \\
\text { Equity } \\
\text { Internal Rate of Return }\end{array}$ & $\begin{array}{l}(23,773) \\
(.27) \\
36,488 \\
\\
123,617 \\
109,509 \\
140 \% \\
111,086\end{array}$ & $\begin{array}{l}(19,697) \\
(.22) \\
29,518 \\
9,821 \\
7,718 \\
11 \% \\
120,497\end{array}$ & $\begin{array}{c}(15,386) \\
(.17) \\
26,901 \\
11,515 \\
8,023 \\
13 \% \\
130,626\end{array}$ & $\begin{array}{c}(10,386) \\
(.12) \\
23,966 \\
13,168 \\
8,134 \\
15 \% \\
141,554\end{array}$ & $\begin{array}{l}(6,008) \\
(.07) \\
20,744 \\
14,737 \\
8,070 \\
17^{\%} \\
153,470 \\
58.48 \%\end{array}$ \\
\hline TERMINATION PHASE & YEAR 1 & YEAR 2 & YEAR 3 & YEAR 4 & YEAR 5 \\
\hline $\begin{array}{l}\text { Discounted Net to Sel- } \\
\text { ler. } \\
\text { Total Discounted Return } \\
\text { AT } \\
\text { NPV of Profit } \\
\text { Internal Rate of Return } \\
\text { Investment Value }\end{array}$ & $\begin{array}{l}283,292 \\
392,881 \\
304,498 \\
881,136\end{array}$ & $\begin{array}{l}266,438 \\
383,746 \\
295,363 \\
872,000\end{array}$ & $\begin{array}{l}251,717 \\
377,048 \\
288,665 \\
865,302\end{array}$ & $\begin{array}{l}239,077 \\
372,542 \\
284,159 \\
860,796\end{array}$ & $\begin{array}{l}228,578 \\
370,112 \\
281,729 \\
89.5 \% \\
858,366\end{array}$ \\
\hline
\end{tabular}

space for each unit. The breakdown is comparable to the prices for residential units in the "condominiums only" alternative.

The pessimistic scenario represents the worst possible market conditions in which the units do not appreciate in value. The moderate and optimistic scenarios assume an annual appreciation rate of 2 and 3 percent respectively.

From the termination phase information the investment appears safe. Even if units sell only at the base price, the net present value of pro$f i t$ is $\$ 106,129$. In the more likely event of the property value appreciating, as in the moderate and optimistic scenarios, the NPV is significantly larger (ie. moderate - $\$ 199,044$ and optimistic - $\$ 281,729$ ). In either case the project is yielding much greater than the required rate of return.
The actual rate, the IRR, is $39 \%$ under the pessimistic scenario, $67 \%$ under the moderate and $90 \%$ under the optimistic scenario (if sold in the fifth year). This indicates a significant payoff to the investor which makes the office option attractive if the first floor residential units are not expected to sell easily.

The investment value calculated for the three scenarios supports the previous findings. In the moderate scenario, if the office condominiums are sold in year five, the investment value is $\$ 855,003$. This compares to an actual cost of only $\$ 682,366$, and representing a very good deal. This holds true even under the worst case scenario where the investment value is close to $\$ 110,000$ greater than the actual cost. 


\section{Condominiums With First Floor Offices}

\section{PESSIMISTIC SCENARIO}

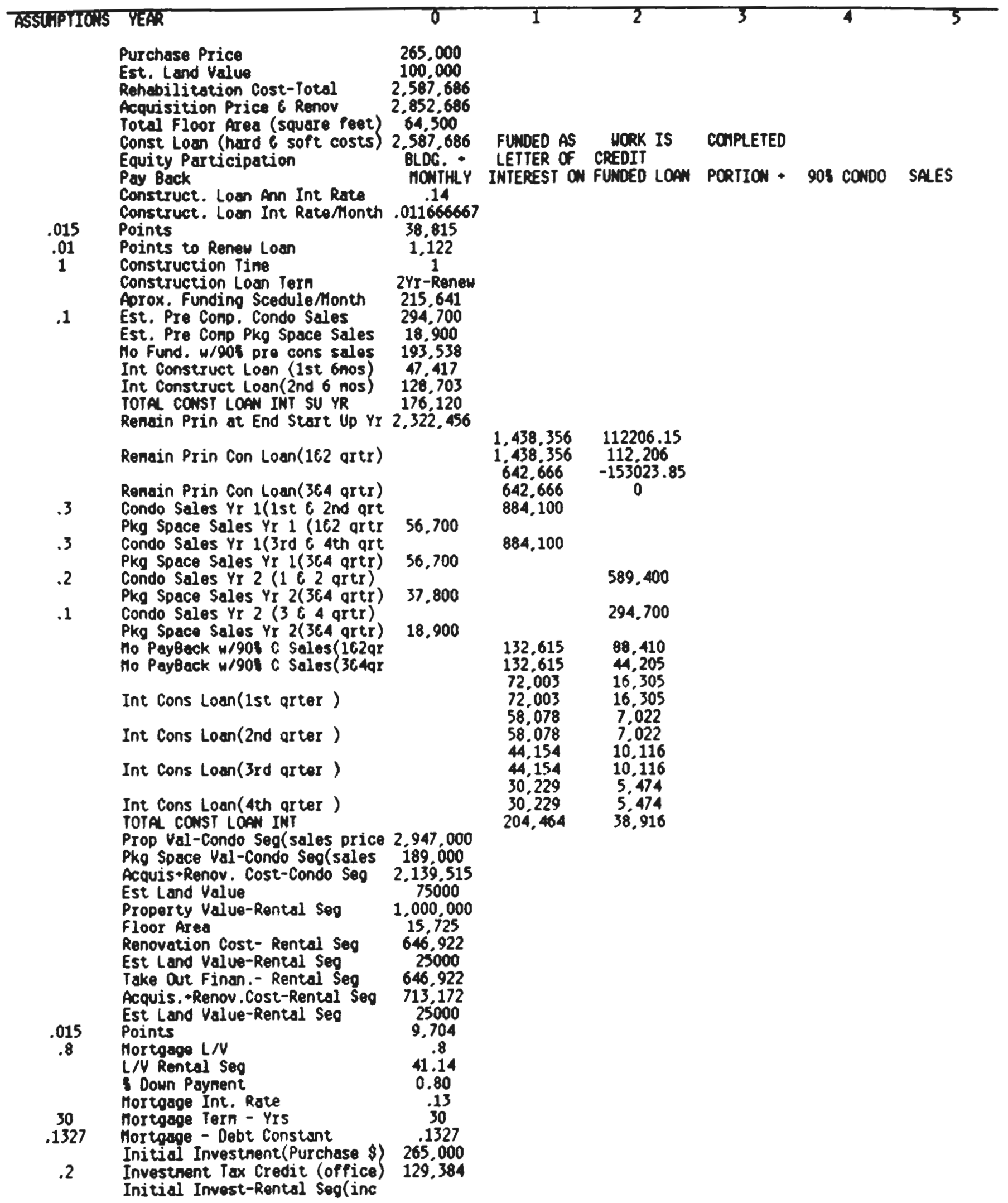




\begin{tabular}{|c|c|c|c|c|c|c|c|}
\hline & & 0 & 1 & 2 & 3 & 4 & 5 \\
\hline .128 & $\begin{array}{l}\text { Cons Loan Int } 6 \text { Points) } \\
\text { Initial Investnent-Condo Seq } \\
\text { Constant for Acc Deprec. } \\
\text { Incone Tax Rate } \\
\text { Econ Life of BIdg } \\
\text { Investor Req. RoI } \\
\text { No of Units } \\
\text { Initial Equity }\end{array}$ & $\begin{array}{l}137.080 \\
137.080 \\
198.750 \\
1.75 \\
0.50 \\
15 \\
.128 \\
46 \\
265.000\end{array}$ & & & & & \\
\hline 0.06 & $\begin{array}{l}\text { CondonINIU G PKG SPACE SALES } \\
\text { Estinated Gross Sale PIice } \\
\text { Brokerage Fees } \\
\text { Net Selling Price } \\
\text { Book Value of Unsold Units } \\
\text { Book Value of Building } \\
\text { Acc Depreciation } \\
\text { Est. Acc Deprec. Unsold Units } \\
\text { SL Depreciation }\end{array}$ & $\begin{array}{c}313.600 \\
18.816 \\
294.784 \\
1.858 .063 \\
\\
123.871\end{array}$ & $\begin{array}{l}1.881 .600 \\
112.896 \\
1.768 .704 \\
855.787\end{array}$ & $\begin{array}{c}940,800 \\
56,448 \\
884,352 \\
0\end{array}$ & & & \\
\hline .5 & $\begin{array}{l}\text { Est SL Deprec. Unsold Units } \\
\text { Book Val of Units\&Spaces Sold } \\
\text { Capital Cains } \\
\text { Depr.Subj.-0rd IncTax (Dep)SL) }\end{array}$ & $\begin{array}{r}213.951 \\
99.649\end{array}$ & $\begin{array}{c}86.709 \\
1.283 .709 \\
597.891\end{array}$ & $\begin{array}{l}68.129 \\
641.854 \\
298.946\end{array}$ & & & \\
\hline .2 & $\begin{array}{l}\text { Ant Subj, - Cap Gains Tax } \\
\text { Capital Gains Tax Rate } \\
\text { TOTAL TAM LIAOILITY(fron sale) } \\
\text { PUIChase Price-Condo Seg } \\
\text { CONDO SEG COSTS }\end{array}$ & $\begin{array}{c}99.649 \\
.2 \\
19,930 \\
198.750\end{array}$ & $\begin{array}{l}597.891 \\
119.578\end{array}$ & $\begin{array}{l}298,946 \\
59,789\end{array}$ & & & \\
\hline $1,940,765$ & $\begin{array}{l}\text { Costruct. Loan Prin-Condo Seg } \\
\text { Const Loan Interest-Condo Seg } \\
\text { Points-Condo Seg }\end{array}$ & $\begin{array}{l}194,076 \\
176,120 \\
29,111\end{array}$ & $\begin{array}{c}1,164,459 \\
153,348 \\
842\end{array}$ & $\begin{array}{l}582,229 \\
29.187\end{array}$ & & & \\
\hline 0.06 & $\begin{array}{l}\text { Brokerage Fees } \\
\text { Tax Liability fron Sales } \\
\text { TOTA COSTS-CONDO SEC } \\
\text { CONOO SEG REVENUES }\end{array}$ & $\begin{array}{l}18,816 \\
19,930 \\
438,053\end{array}$ & $\begin{array}{c}112,896 \\
119,578 \\
1,551,123\end{array}$ & $\begin{array}{l}56,448 \\
59,789 \\
727,654\end{array}$ & & & \\
\hline .05375 & $\begin{array}{l}\text { SUn of Tax Deductibles } \\
\text { Fed Tax Shelter } \\
\text { MaSS St Tax Shelter } \\
\text { TOTAL TAX SHELTER } \\
\text { CONdOMiniUn \& PKg Space Sales } \\
\text { TOTAL REVENUES- CONDO SEG } \\
\text { TOTAL AFTER TAX RETURN } \\
\text { CIM AFTER TAX RETURN } \\
\text { DISC. RETURN } \\
\text { TOTAL DISC. RETURN } \\
\text { NPV OF PROFIT } \\
\text { ROI AFTER TAXES (CUn) }\end{array}$ & $\begin{array}{c}224,047 \\
112,024 \\
12.043 \\
124,066 \\
313,600 \\
437,666 \\
(387) \\
(387) \\
(387) \\
(387) \\
(199.137) \\
(0.00)\end{array}$ & $\begin{array}{c}267,086 \\
133,543 \\
14,356 \\
147,899 \\
1,881,600 \\
2,029,499 \\
478,376 \\
477,989 \\
424,092 \\
423,705 \\
224,955 \\
2.40\end{array}$ & $\begin{array}{l}85.635 \\
42,818 \\
4.603 \\
47,421 \\
940,800 \\
988.221 \\
250,567 \\
738.556 \\
204,786 \\
628.491 \\
429.741 \\
3.72\end{array}$ & & & \\
\hline $\begin{array}{l}\text { TRY OF'S } \\
\text { TILL NPV }=0 \\
\text { MUST RECALC }\end{array}$ & $\begin{array}{l}\text { INTERHAL RATE OF RETURN } \\
\text { Trial Disc Factor } \\
\text { Total Disc Return (Trial OF) } \\
\text { Cun TOtal Disc Return(Trial DF } \\
\text { Net Present Value } \\
\text { INTERNA RATE OF RETURN } \\
\text { INUESTHENT VALUE-Condo SEg }\end{array}$ & $\left.\begin{array}{c}1.86 \\
(387) \\
387\end{array}\right)$ & $\begin{array}{l}167.264 \\
166,877 \\
2.364,470\end{array}$ & $\begin{array}{c}31,856 \\
198.733 \\
(17) \\
186.0 \\
2.569 .256\end{array}$ & & & \\
\hline .05 & $\begin{array}{l}\text { REVENUE FROH RENTALS } \\
\text { Ho. Rent Type } \| 1 \\
\text { No. of Type } \# 1 \text { Units }\end{array}$ & 3 & 500 & 525 & 551 & 579 & 608 \\
\hline .05 & $\begin{array}{l}\text { No. Rent Type } 12 \\
\text { No. of Type } 12 \text { Units }\end{array}$ & 3 & 600 & 630 & 662 & 695 & 729 \\
\hline .05 & $\begin{array}{l}\text { No. Rent Type } 113 \\
\text { No. of Type } 113 \text { Urites }\end{array}$ & 6 & 700 & 735 & 772 & 810 & 851 \\
\hline $\begin{array}{l}1.05 \\
.05 \\
.01\end{array}$ & $\begin{array}{l}\text { Ho Pkg Rental for } 12 \text { Spaces } \\
\text { GROSS SCHED INCONE } \\
\text { Vacancy Allowance } \\
\text { Bad Debt Allow. } \\
\text { EFFECTIVE GROSS INC RENTALS } \\
\text { EXPENSES FOR RENTALS }\end{array}$ & 12 Units & $\begin{array}{c}600 \\
97,200 \\
29,160 \\
972 \\
67,068\end{array}$ & $\begin{array}{c}630 \\
102,060 \\
5,103 \\
1,021 \\
95,936\end{array}$ & $\begin{array}{c}662 \\
107,163 \\
5,358 \\
1,072 \\
100,733\end{array}$ & $\begin{array}{c}695 \\
112.521 \\
5.626 \\
1.125 \\
105.770\end{array}$ & $\begin{array}{c}729 \\
118,147 \\
5,907 \\
1,181 \\
111,058\end{array}$ \\
\hline $\begin{array}{l}.025 \\
.09 \\
.09 \\
.59\end{array}$ & $\begin{array}{l}\text { Property Taxes } \\
\text { Insur ance } \\
\text { Uater/Sewer } \\
\text { Adninistration/Manangenent }\end{array}$ & & $\begin{array}{l}25.000 \\
1,415 \\
1,415 \\
9.278\end{array}$ & $\begin{array}{l}25.500 \\
1.444 \\
1.444 \\
9.463\end{array}$ & $\begin{array}{l}26.010 \\
1.472 \\
1.472 \\
9.653\end{array}$ & $\begin{array}{l}26.530 \\
1.502 \\
1.502 \\
9.846\end{array}$ & $\begin{array}{c}27.061 \\
1.532 \\
1.532 \\
10.043\end{array}$ \\
\hline
\end{tabular}




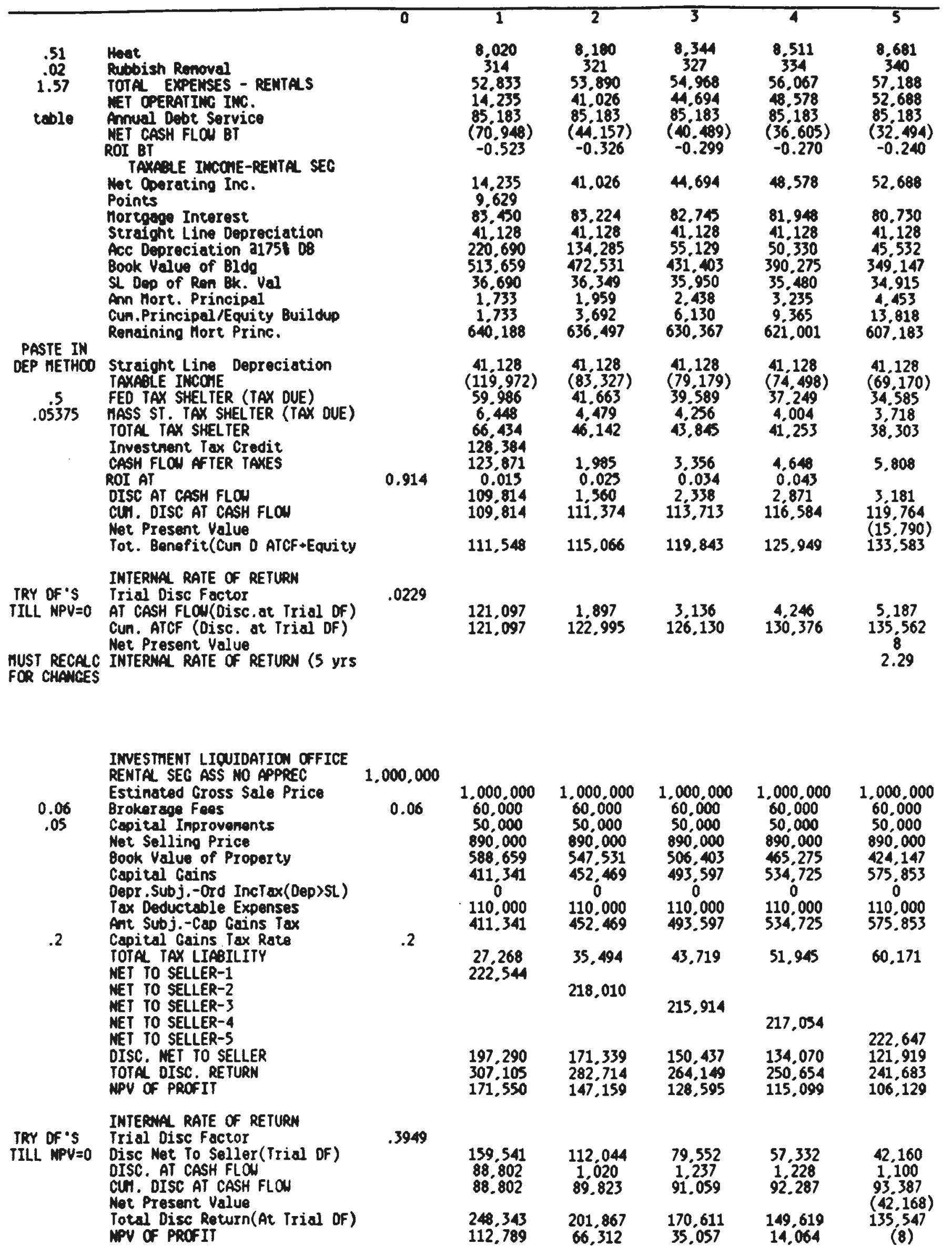




\section{$\mathbf{0}$}

MUST RECAL INTERMAL RATE OF RETURN (5 yTS FOR CHANCES

INVESTHENT VALUE

KEY IMDICATORS

OFFICE RENTAL SEGHENT

OPERATION PHASE

NET Before TaX CASH FLOH

ROI BT

TOTAL TAX SHELTER - ST \& FEO

After Tax Cash Flow

DISC. AT CASH FLOW

ROI AT

CU. DISC AT CASH FLO

Disc. Total Benefit (ATCF - Equity)

MUST RECALC INTERNAL RATE OF RETURN ( 5 yIS FOR CHAWCES

TERIIHATION PHASE

USINC EST. ANH APPREC . $=0$

Estinated Gross Sale Price

DISC. NET TO SELLER

TOTAL DISC. RETURN

MPV OF PROFIT

MUST RECALC INTERNAL RATE OF RETURN (5 yIS FOR CHANGES

INUESTMENT VAUUE

RESIUENTIAL CONDCMINIUN SEG

INUESTHENT LIOUIDATIOY

Estinated Gross Sale Price

TOTAL TAK SHELTER - ST G FED

ROI AFTER TAXES

TOTAL DISC. RETURN

MPV OF PROFI

MUST RECALC INTERNAL RATE OF RETURN (5 y FOR CHAMCES

INUESTMENT VALUE
1

82.776

858.385

839.821

826,325

39.49

817.355

$\begin{array}{ccccc}(70.948) & (44.157) & (40.489) & (36.605) & (32.494) \\ (0.52) & (0.33) & (0.30) & (0.27) & (0.24) \\ 66.434 & 46.142 & 43.845 & 41.253 & 38.303 \\ 123.871 & 1.985 & 3.356 & 4.648 & 5.808 \\ 109.814 & 1.560 & 2.338 & 2.871 & 3.181 \\ 0.91 & 0.01 & 0.02 & 0.03 & 0.04 \\ 109.814 & 111.374 & 113.713 & 116.584 & 119.764 \\ 111.548 & 115.066 & 119.843 & 125.949 & 133.583 \\ & & & & \end{array}$

$\begin{array}{ccccc}1,000,000 & 1,000,000 & 1,000.000 & 1,000,000 & 1.000 .000 \\ 197.290 & 171.339 & 150.437 & 134.070 & 121.919 \\ 307.105 & 282.714 & 264.149 & 250.654 & 241.683 \\ 171.550 & 147.159 & 128.595 & 115.099 & 106.129 \\ & & & & 39.49\end{array}$

$\begin{array}{lllll}882.776 & 858.385 & 839.821 & 826.325 & 817.355\end{array}$

$\begin{array}{ccc}313.600 & 1.881 .600 & 940.800 \\ 124.066 & 147.899 & 47.421 \\ (0.00) & 2.40 & 3.72 \\ (387) & 423.705 & 628.491 \\ (199.137) & 224.955 & 429.741 \\ & & 186.0\end{array}$

$1.940 .377 \quad 2.364 .470 \quad 2.569 .256$ 


\section{Condominiums With First Floor Offices MODERATE SCEMARIO}

Purchase Price

265.000

Ext. Lend Valu

100,000

Pehobilitotion Cost-Total

2.44 .463

Aoquigition Pries 6 Renow

$2,729,433$

Total floor Ares (souare foot) 64,500

const loen (hard 6 soft costs) 2,44,433

Equity Partigipation

.40. 4.33

Fumed as une Is

COMPETED

Par Deck

Construct. Laen inn Int Rete

Construst. Law Int Ratemonth .01166s67

.015 Points

.01 Points to Amen Laen

1 Construction Iin

Construction Loen Tern

36. 967

.1

Est. PI Con Condo salenth

Est. Pre Comp pien sose sales

Ho fund. w/ses pro cons cales

Int Construct Loen (1st 6not)

Int Construct Losn(2nd 6 nos)

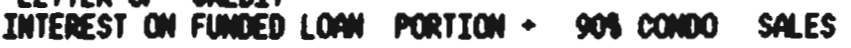
.14

Rersin Pin at End start of $Y_{1} 2,164,763$

Amain Prin Con Laen(162 artr)

Bamain Prin Con Lan (364 artr)

. 4 Condo Sales h 1(1st 6 2nd qut

Pko sper sales Yr 1 (162 qreT

.4 Condo sales Yr 1(3rd o th qrt

1 Pkg spece Sales Vr 1 (3et qrer)

1 Condo Sales H 2 (1 6 2 artr)

- Pro space Sales Yr 2(3et qrer) Condo sales ir 2 ( 364 qrtr) Ple space sales Vr 2(364 qrtr)

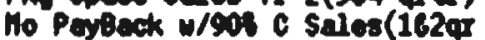
Ho Paybock w/90 C Sales(304qr

Int Cons Lan(1st qrter )

Int Cons Lasn(2nd qrer)

Int cons $\operatorname{Lan}(3 \mathrm{rd}$ qut )

Int Coms Losn(4th grter )

TOTAL Const Low INT

Prop Val-Condo sen (sales orice 3,350 000

Pro spece Val-condo sen(tales 210,000

Acovisthinov. Cost-conds Sed 2.047,097

Est Land Valie 75000

property Valus-Rental Seo $1,000,000$

Floor Area

15,725

Renovation cost- Pental sen 616,116

Est Land Value-Rental Seg 23000

Tate out Find - Pental Seg 616.116

Acquis. - henow. Cost-Rental sed 692,366

Est Land Valu-Rental seo silom

.015 Points

.8 Hortgee LN

LN Rental Seo

S Down Payment

hortoage Int. Race

30 Hortoag Tarn - Yrs

Hor hortas Tern - Yis

Initial Investment (Purchase 8)

Imvertumt $\operatorname{Tax}$ Credit (opfice)

Initial Inwert-Rental Seo(inc

Cons Las Int 6 Points)

9.242

.8

39.18

0.80

.13

30

.1327

265.000

123.223

106.093

10.093 .015

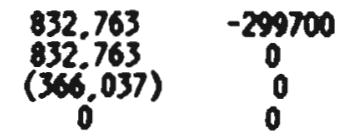

$1,332,000$

1.332 .000

333.000

0

199.000

199,000

61,781

61.781

4.802

4.802

19.823

19.823

(1, 156) (1)

122, 405 


\begin{tabular}{|c|c|c|c|c|c|c|c|}
\hline & & 0 & 1 & 2 & 3 & 4 & 5 \\
\hline .128 & $\begin{array}{l}\text { Initial Investnent-Condo Seg } \\
\text { Constent for Acc Deprec. } \\
\text { Incom Tax Rate } \\
\text { Econ LIfe of B1dp } \\
\text { Investor Req. RoI } \\
\text { No. of Units } \\
\text { Initial Equity }\end{array}$ & $\begin{array}{c}198.750 \\
1.75 \\
0.50 \\
15 \\
.128 \\
40 \\
265.000\end{array}$ & & & & & \\
\hline 0.06 & $\begin{array}{l}\text { CowonINIM G PKG SPACE SALES } \\
\text { Estinated Gross Sole Price } \\
\text { Brokerage Fees } \\
\text { Nat Selling Price } \\
\text { Book Value of Unsold Units } \\
\text { Book Value of Building } \\
\text { Acc Depreciation } \\
\text { Est. Acc Deprec. Unsold Units } \\
\text { SL Depreciation }\end{array}$ & $\begin{array}{l}354,000 \\
21,240 \\
332,760 \\
1,774,888 \\
118,326\end{array}$ & $\begin{array}{l}2,832,000 \\
169,920 \\
2,662,080 \\
409,410\end{array}$ & $\begin{array}{l}354,000 \\
21,240 \\
332,760 \\
(0)\end{array}$ & & & \\
\hline & $\begin{array}{l}\text { Est SL Deprec. Unsold Units } \\
\text { Book Val of Unitsespaces Sold } \\
\text { Capital Gains }\end{array}$ & $\begin{array}{l}204,710 \\
149,290\end{array}$ & $\begin{array}{l}70,995 \\
1,637,678 \\
1,194,322\end{array}$ & $\begin{array}{l}65,079 \\
204,710 \\
149,290\end{array}$ & & & \\
\hline .5 & $\begin{array}{l}\text { Depr Subj, - Ord IncTax(Dep)SL) } \\
\text { Ant Subj, - Cad Gains Tax }\end{array}$ & 149.290 & 1.194 .322 & 149.290 & & & \\
\hline .2 & $\begin{array}{l}\text { Capital Gains Tax Rate } \\
\text { TOTAL TAX LIABILITY(fron sale) } \\
\text { Purchase Price-Condo Seg } \\
\text { CONDO SEG COSTS }\end{array}$ & $\begin{array}{c}.2 \\
29.858 \\
198.750\end{array}$ & 238.864 & 29.858 & & & \\
\hline $1,848,347$ & $\begin{array}{l}\text { Costruct. Loan Prin-Condo Seg } \\
\text { Const Loan Interest-Condo Seg } \\
\text { Points-Condo Seg }\end{array}$ & $\begin{array}{l}184.835 \\
164.161 \\
27.725\end{array}$ & $\begin{array}{c}1,478,678 \\
91,804 \\
0\end{array}$ & $\begin{array}{c}184,835 \\
0\end{array}$ & & & \\
\hline 0.06 & $\begin{array}{l}\text { Br okerage Fees } \\
\text { Tax Liability Fron Sales } \\
\text { TOTAL COSTS-CONDO SEG } \\
\text { CONDO SEG REVENUES }\end{array}$ & $\begin{array}{l}21.240 \\
29.858 \\
427.819\end{array}$ & $\begin{array}{c}169.920 \\
238,864 \\
1,979.266\end{array}$ & $\begin{array}{l}21.240 \\
29.858 \\
235.933\end{array}$ & & & \\
\hline .05375 & 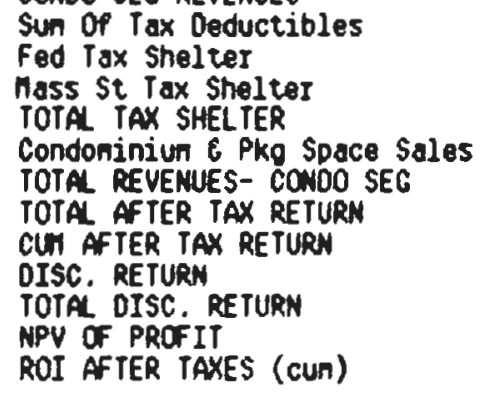 & $\begin{array}{c}213.126 \\
106.563 \\
11,456 \\
118,019 \\
354.000 \\
472,019 \\
44.200 \\
44,200 \\
44,200 \\
44,200 \\
(154,550) \\
0.22\end{array}$ & $\begin{array}{c}261.724 \\
130.862 \\
14.068 \\
144,930 \\
2.832 .000 \\
2.976 .930 \\
997.663 \\
1.041 .863 \\
884.453 \\
928.653 \\
729.903 \\
5.24\end{array}$ & $\begin{array}{c}21,240 \\
10,620 \\
1,142 \\
11,762 \\
354.000 \\
365.762 \\
129.829 \\
1,171,692 \\
102,036 \\
1,030.689 \\
831,939 \\
5.90\end{array}$ & & & \\
\hline $\begin{array}{l}\text { TRY OF'S } \\
\text { IILL MPV }=0 \\
\text { NUST RECALC }\end{array}$ & $\begin{array}{l}\text { INTERNAL RATE OF RETURH } \\
\text { Trial Disc Factor } \\
\text { Totsl Oisc Return (Trial DF) } \\
\text { CUn Total Disc Return(Trial of } \\
\text { Net Present Value } \\
\text { INTERNAL RATE of RETURN } \\
\text { INUESTHENT VALUE-Condo SEO }\end{array}$ & $\begin{array}{r}5.584 \\
44.200 \\
44.200 \\
1.892 .547\end{array}$ & $\begin{array}{l}151.528 \\
195.728 \\
2.777 .000\end{array}$ & $\begin{array}{c}2,995 \\
198,723 \\
(27) \\
558.4 \\
2.879 .036\end{array}$ & & & \\
\hline .05 & $\begin{array}{l}\text { REVENUE FROA RENTALS } \\
\text { Mo. Rent Type HI }\end{array}$ & 3 & 500 & 525 & 551 & 579 & 608 \\
\hline .05 & Ho. Rent Type "I2 & 3 & 600 & 630 & 662 & 695 & 729 \\
\hline .05 & $\begin{array}{l}\text { No. Rent Type "I3 } \\
\text { No. of Type } 113 \text { Units }\end{array}$ & 6 & 700 & 735 & 772 & 810 & 851 \\
\hline 1.05 & $\begin{array}{l}\text { Mo Pko Rental for } 12 \text { Spaces } \\
\text { GROSS SCHED INCONE }\end{array}$ & 12 & $\begin{array}{l}600 \\
97.200\end{array}$ & $\begin{array}{c}630 \\
102,060\end{array}$ & $\begin{array}{c}662 \\
107,163\end{array}$ & $\begin{array}{c}695 \\
112.521\end{array}$ & $\begin{array}{c}729 \\
118,147\end{array}$ \\
\hline $\begin{array}{l}.05 \\
.01\end{array}$ & $\begin{array}{l}\text { Vacancy Allowance } \\
\text { Bad Debt Allow. } \\
\text { EFFECIIVE GROSS INC RENTALS } \\
\text { EXPENSES FOR RENTASS }\end{array}$ & 12 Units & $\begin{array}{r}4,860 \\
972 \\
91,368\end{array}$ & $\begin{array}{l}5,103 \\
1,021 \\
95,936\end{array}$ & $\begin{array}{c}5,358 \\
1,072 \\
100,733\end{array}$ & $\begin{array}{c}5,626 \\
1,125 \\
105,770\end{array}$ & $\begin{array}{c}5,907 \\
1,181 \\
111,058\end{array}$ \\
\hline $\begin{array}{l}.025 \\
.09 \\
.09 \\
.59 \\
.47 \\
.51\end{array}$ & $\begin{array}{l}\text { Property Taxes } \\
\text { Insur ance } \\
\text { Water/Sewer } \\
\text { Adninistration/Manangenent } \\
\text { Repairs/Maintenance/Security } \\
\text { Heat }\end{array}$ & & $\begin{array}{l}25.000 \\
1.415 \\
1.415 \\
9.278 \\
7.391 \\
8.020\end{array}$ & $\begin{array}{l}25.500 \\
1.444 \\
1.444 \\
9.463 \\
7.539 \\
8.180\end{array}$ & $\begin{array}{l}26.010 \\
1.472 \\
1.472 \\
9.653 \\
7.689 \\
8.344\end{array}$ & $\begin{array}{l}26.530 \\
1.502 \\
1.502 \\
9.846 \\
7.843 \\
8.511\end{array}$ & $\begin{array}{l}27.061 \\
1,532 \\
1.532 \\
10.043 \\
8.000 \\
8.681\end{array}$ \\
\hline
\end{tabular}




\begin{tabular}{|c|c|c|c|c|c|c|c|}
\hline $\begin{array}{l}1.57 \\
\text { table }\end{array}$ & 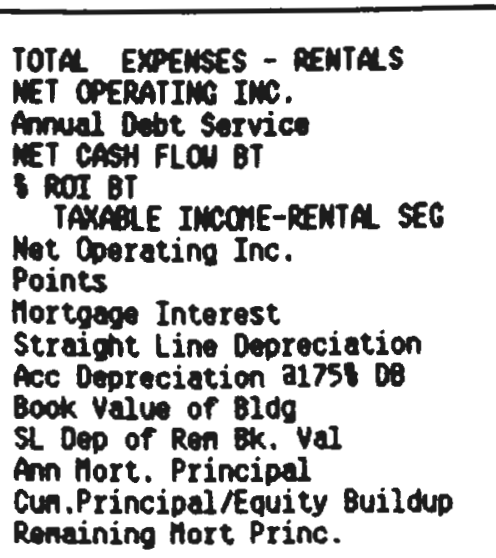 & $\overline{0}$ & $\begin{array}{c}1 \\
52.833 \\
38.535 \\
81.759 \\
(43.224) \\
-0.407 \\
38.535 \\
9.242 \\
80.095 \\
39.408 \\
260.026 \\
494.735 \\
35.338 \\
1.664 \\
1.664 \\
614.452\end{array}$ & $\begin{array}{c}2 \\
53.890 \\
42.046 \\
81.759 \\
(39.712) \\
-0.374 \\
42.046 \\
79.879 \\
39.408 \\
81.602 \\
955.327 \\
35.025 \\
1.880 \\
3.543 \\
610.909\end{array}$ & $\begin{array}{c}3 \\
54.968 \\
45.766 \\
81.759 \\
(35.993) \\
-0.339 \\
45.766 \\
79.418 \\
39.408 \\
53.122 \\
415.919 \\
34.660 \\
2.340 \\
5.884 \\
605.025\end{array}$ & $\begin{array}{c}4 \\
56.057 \\
49.703 \\
81.759 \\
(32.056) \\
-0.302 \\
49.703 \\
78.653 \\
39.408 \\
48.524 \\
376.512 \\
34.228 \\
3.105 \\
8.989 \\
596.036\end{array}$ & $\begin{array}{c}5 \\
57.186 \\
53.870 \\
81.759 \\
(27.899) \\
-0.263 \\
53.870 \\
77.485 \\
39.408 \\
43.926 \\
337.104 \\
33.710 \\
4.274 \\
13.263 \\
582.774\end{array}$ \\
\hline \multirow[t]{3}{*}{$\begin{array}{l}\text { PASTE IN } \\
\text { DEP METHOO } \\
.05375\end{array}$} & $\begin{array}{l}\text { Straight Line Deprociation } \\
\text { TAKAELE IMCONE } \\
\text { FED TAK SHELTER (TAK OUE) } \\
\text { MASS ST TAX SHELTER (TAK DUE) } \\
\text { TOTAL TAX SHELTER } \\
\text { Investnent TaX Gredit }\end{array}$ & & $\begin{array}{l}39.408 \\
(90.210) \\
45.105 \\
4.849 \\
49.954 \\
193.223\end{array}$ & $\begin{array}{l}39.408 \\
(77.240) \\
38.620 \\
4.152 \\
42.772\end{array}$ & $\begin{array}{l}39.408 \\
(73.060) \\
36.530 \\
3.927 \\
40.457\end{array}$ & $\begin{array}{l}39.408 \\
(68.358) \\
34.179 \\
3.674 \\
37.853\end{array}$ & $\begin{array}{l}39.408 \\
(63.022) \\
31.511 \\
3.387 \\
34.899\end{array}$ \\
\hline & $\begin{array}{l}\text { CASH FLOH AFTER TAKES } \\
\text { ROI AT } \\
\text { DISC AT CASH FLOH } \\
\text { CWH. DISC AT CASH FLOW } \\
\text { Net Present Value }\end{array}$ & & $\begin{array}{r}129.953 \\
1.225 \\
115.207 \\
115.207\end{array}$ & $\begin{array}{c}3.060 \\
0.029 \\
2.405 \\
117.611\end{array}$ & $\begin{array}{c}4.464 \\
0.042 \\
3.110 \\
120.722\end{array}$ & $\begin{array}{c}5.798 \\
0.055 \\
3.581 \\
124.303\end{array}$ & \multirow{2}{*}{$\begin{array}{c}7.010 \\
0.066 \\
3.839 \\
128.141 \\
22.048 \\
141.404\end{array}$} \\
\hline & Tot. Benefit(Cun O ATCF+Equity & & 116.870 & 121,154 & 126.605 & 133.292 & \\
\hline $\begin{array}{l}\text { MUST RECALC } \\
\text { FOR CHAWGES }\end{array}$ & $\begin{array}{l}\text { INTERHAL RATE of RETURN } \\
\text { Trial Disc Factor } \\
\text { AT CASH FLOW(Disc.at Trial DF) } \\
\text { Cun. ATCF (Disc, at Trial of) } \\
\text { Net Present Value } \\
\text { INTERNAL RATE of RETURN (5 yrs }\end{array}$ & .317 & $\begin{array}{l}98.673 \\
98.673\end{array}$ & $\begin{array}{c}1.764 \\
100.437\end{array}$ & $\begin{array}{c}1,954 \\
102.392\end{array}$ & $\begin{array}{l}1.927 \\
104.319\end{array}$ & $\begin{array}{c}1.769 \\
106.088 \\
(5) \\
31.70\end{array}$ \\
\hline .02 & $\begin{array}{l}\text { INVESTMENT LIQUIDATION OFFICE } \\
\text { RENTAL SEC ASS } 2 \text { APPREC }\end{array}$ & $1,000,000$ & & & & & \\
\hline $\begin{array}{l}0.06 \\
.05\end{array}$ & $\begin{array}{l}\text { Estinated Gross Sale Price } \\
\text { Brokerege Fees } \\
\text { Capital Inprovenents } \\
\text { Net Selling Price } \\
\text { Book Value of Property } \\
\text { Capital Gains } \\
\text { Depr. Subj. -Ord IncTax (Dep)SL) } \\
\text { Tax Deductable Expenses } \\
\text { Ant Subj.-Cap Gains Tax } \\
\text { Capital Gains Tax Rate }\end{array}$ & 0.06 & $\begin{array}{l}1.020 .000 \\
61.200 \\
51.000 \\
907.800 \\
570.735 \\
49.265 \\
0 \\
112.200 \\
449.265\end{array}$ & $\begin{array}{l}1.040 .400 \\
62.424 \\
52.020 \\
925.956 \\
532.347 \\
508.053 \\
0 \\
114.444 \\
508.053\end{array}$ & $\begin{array}{l}1.061 .208 \\
63.672 \\
53.060 \\
944.475 \\
493.980 \\
567.228 \\
0 \\
116.733 \\
567.228\end{array}$ & $\begin{array}{l}1.082 .432 \\
64.946 \\
54.122 \\
963.365 \\
455.633 \\
626.799 \\
0 \\
119.068 \\
626.799\end{array}$ & $\begin{array}{l}1.104 .081 \\
66.243 \\
55.204 \\
982.632 \\
417.308 \\
686.773 \\
0 \\
121.449 \\
686.773\end{array}$ \\
\hline \multirow{2}{*}{.2} & $\begin{array}{l}\text { TOTAL TAK LIABILITY } \\
\text { NET TO SELLER-1 } \\
\text { NET TO SELLER-2 } \\
\text { NET TO SELLER-3 } \\
\text { NET TO SELLER-4 } \\
\text { NET TO SFLLER-5 }\end{array}$ & & $\begin{array}{l}33.753 \\
259.595\end{array}$ & $\begin{array}{r}44.389 \\
270.658\end{array}$ & 55.079 & 301,502 & 76.630 \\
\hline & $\begin{array}{l}\text { NETS MET TO SELLER } \\
\text { DISC. OTAL OISC. RETURN } \\
\text { NPV OF PROFIT }\end{array}$ & & $\begin{array}{l}230.137 \\
345.344 \\
239.251\end{array}$ & $\begin{array}{l}212.718 \\
330.329 \\
224.236\end{array}$ & $\begin{array}{l}198.133 \\
318.855 \\
212.762\end{array}$ & $\begin{array}{l}186.232 \\
310.533 \\
204.412\end{array}$ & $\begin{array}{l}323.228 \\
176.996 \\
305.137 \\
199.044\end{array}$ \\
\hline \multirow{4}{*}{$\begin{array}{l}\text { TRY OF' 'S } \\
\text { TILL NPY=0 } \\
\text { MUST RECAL } \\
\text { FOR CHAWCES }\end{array}$} & $\begin{array}{l}\text { INTERNAL RATE of RETURN } \\
\text { Trial Disc Factor }\end{array}$ & .6695 & & & & & \multirow{3}{*}{$\begin{array}{c}24.922 \\
540 \\
81.183 \\
(24.910) \\
106.105 \\
12 \\
66.95\end{array}$} \\
\hline & $\begin{array}{l}\text { Disc Not To Seller (Trial DF) } \\
\text { DISC. AT CASH FLOH } \\
\text { CUH. OISC AT CASH FLO } \\
\text { Net Present Value }\end{array}$ & & $\begin{array}{l}155.493 \\
77.839 \\
77.839\end{array}$ & $\begin{array}{l}97.107 \\
1.098 \\
78.937\end{array}$ & $\begin{array}{l}61.112 \\
959 \\
79.897\end{array}$ & $\begin{array}{l}38.810 \\
746 \\
80.643\end{array}$ & \\
\hline & $\begin{array}{l}\text { Total Disc Return(At Trial DF) } \\
\text { MPV OF PROFIT } \\
\text { INTERHAL RATE OF RETURN ( } 5 \text { yrs }\end{array}$ & & $\begin{array}{l}233.332 \\
127.239\end{array}$ & $\begin{array}{l}176.044 \\
69.951\end{array}$ & $\begin{array}{c}141.008 \\
34.915\end{array}$ & $\begin{array}{l}119.453 \\
13.360\end{array}$ & \\
\hline & INVESTMENT VALUE & & 895.209 & 880.195 & 868.721 & 860.400 & 855.003 \\
\hline
\end{tabular}


0

KEY INOICATORS

OFFICE RENTAL SECHENT

OPERATION PHASE

MET 8oforo Tax CASH FLOU

ROI BT

TOTAL TAK SHELTER - ST G FED

After Tax Cash Flow

ROI AT

Disc.

Total 8enefit (ATCF + Equity)

HUST RECALC INTERNAL RATE OF RETURN ( 5 yTS

FOR CHAWCES

TERIINATION PHASE

USINC EST. ANN APPREC. $=0$

Estinated Gross Sale Price

OISC. NET TO SELLER

TOTAL OISC. RETURN

NPV OF PROFIT

MUST RECALC INTERMAL RATE OF RETURN (5 yrs FOR CHANCES

INVESTMENT VALUE

INUESTHENT LIOUIDATION

Estinated Gross Sale Price TOTAL TAX SHELTER - ST E FEO ROI AFTER TAXES

TOTAL DISC. RETURN

MPV OF PROFIT

MUST RECALC INTERNAL RATE OF RETURN (S YTS FOR CHAHCES

INVESTMENT VALUE

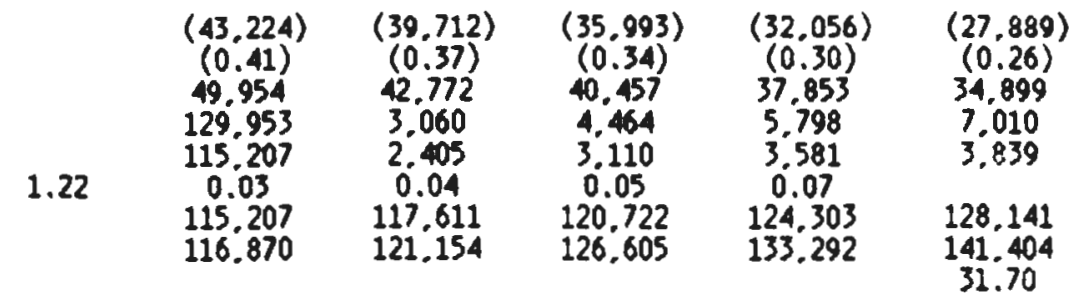

$\begin{array}{ccccc}1,020,000 & 1,040,400 & 1,061.208 & 1,082,432 & 1,104.081 \\ 230.137 & 212.718 & 198.133 & 186.232 & 176.996 \\ 345.344 & 330.329 & 318.855 & 310.535 & 305.137 \\ 239.251 & 224,236 & 212.762 & 204.442 & 199.044\end{array}$

$\begin{array}{lllll}895,209 & 880.195 & 868.721 & 860.400 & 855.003\end{array}$

RESIDENTIAL CONDOAINIU SEG

$\begin{array}{ccc}354.000 & 2.832 .000 & 354.000 \\ 118.019 & 144.930 & 11.762 \\ 0.22 & 5.24 & 5.90 \\ 44.200 & 928.653 & 1.030 .689 \\ (154.550) & 729.903 & 831,939 \\ & & 558.4 \\ & & \\ 1.892 .547 & 2.777 .000 & 2.879 .036\end{array}$




\section{Condominiums With First Floor Offices OPTIMISTIC SCENARIO}

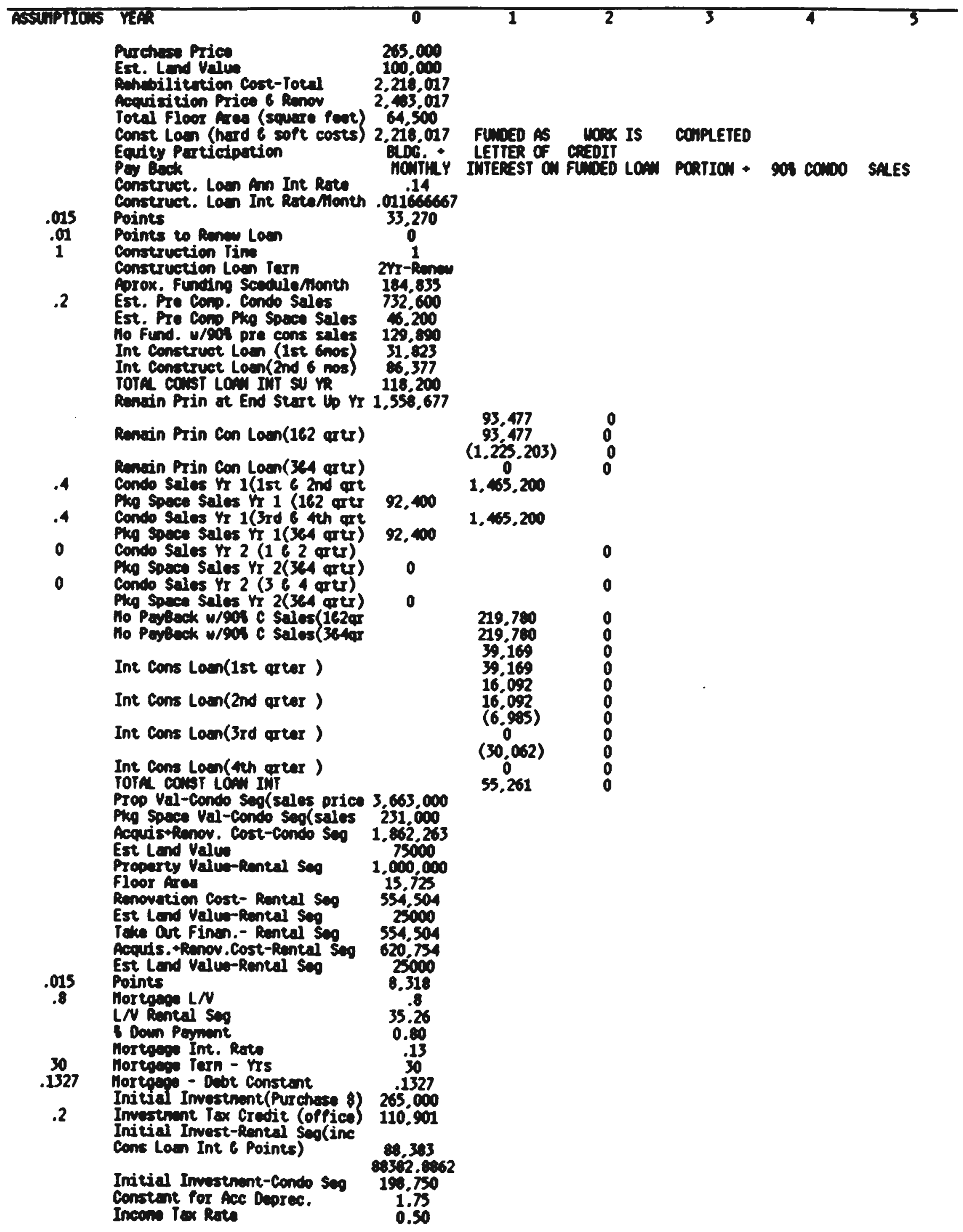




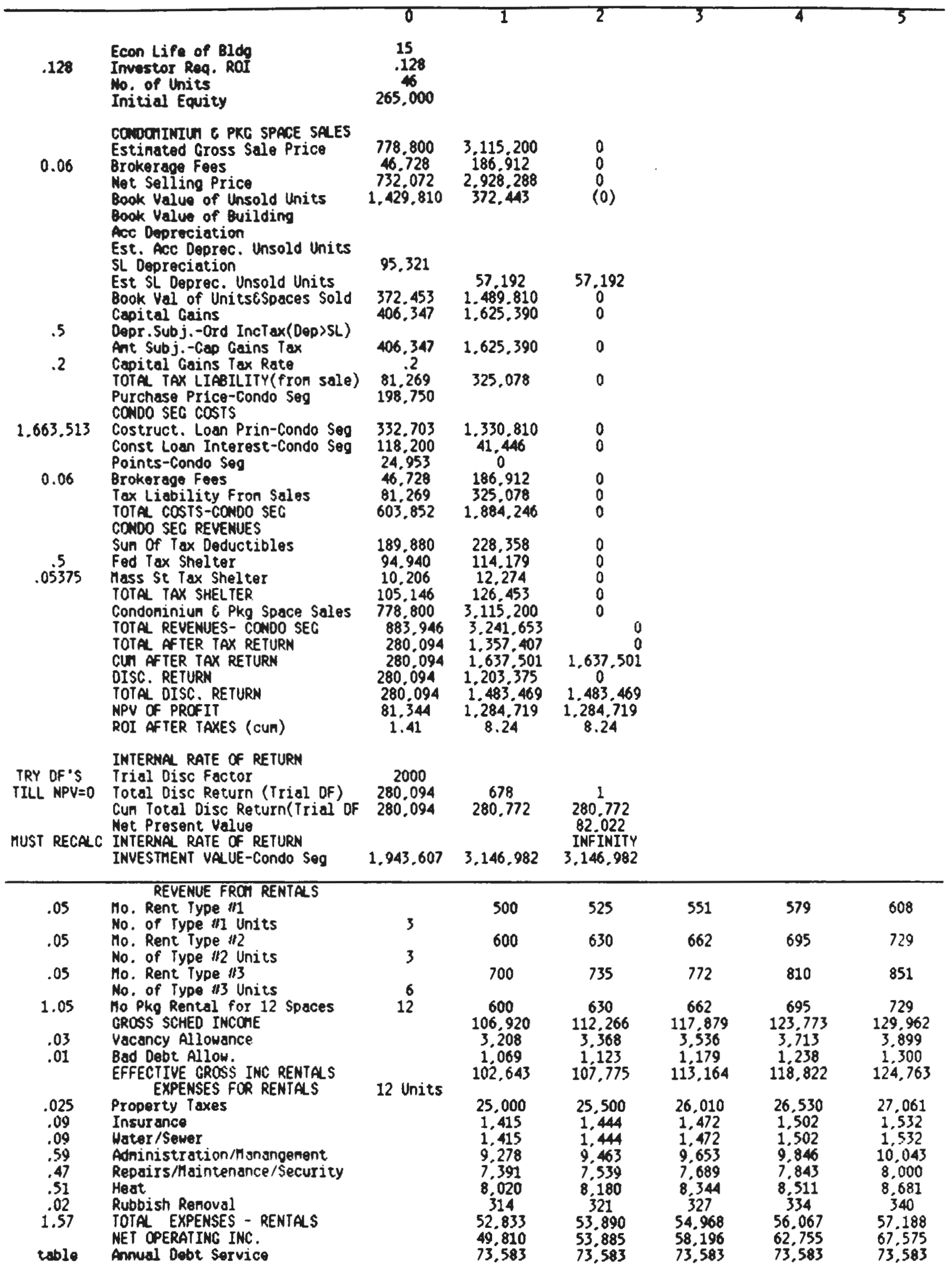




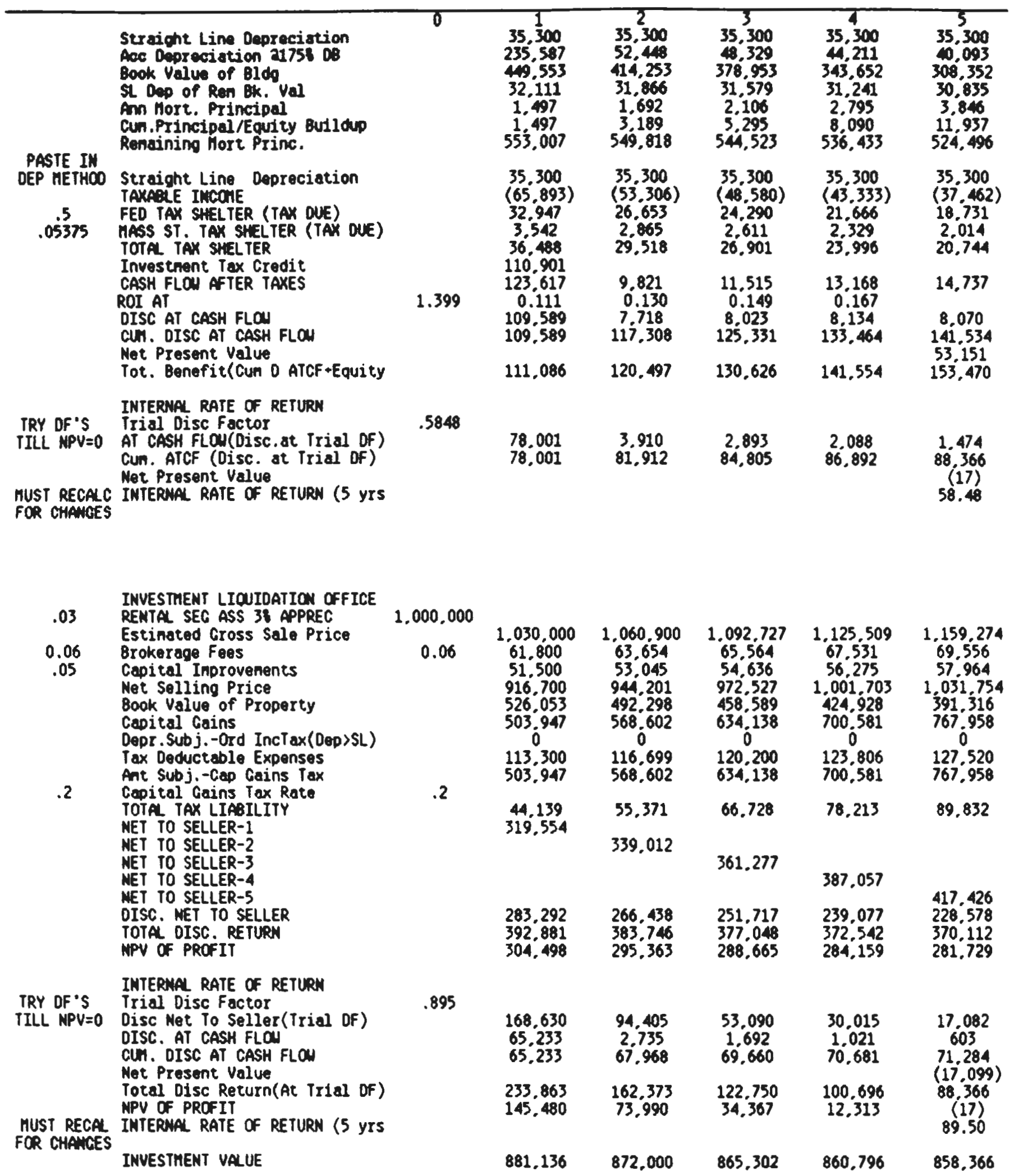




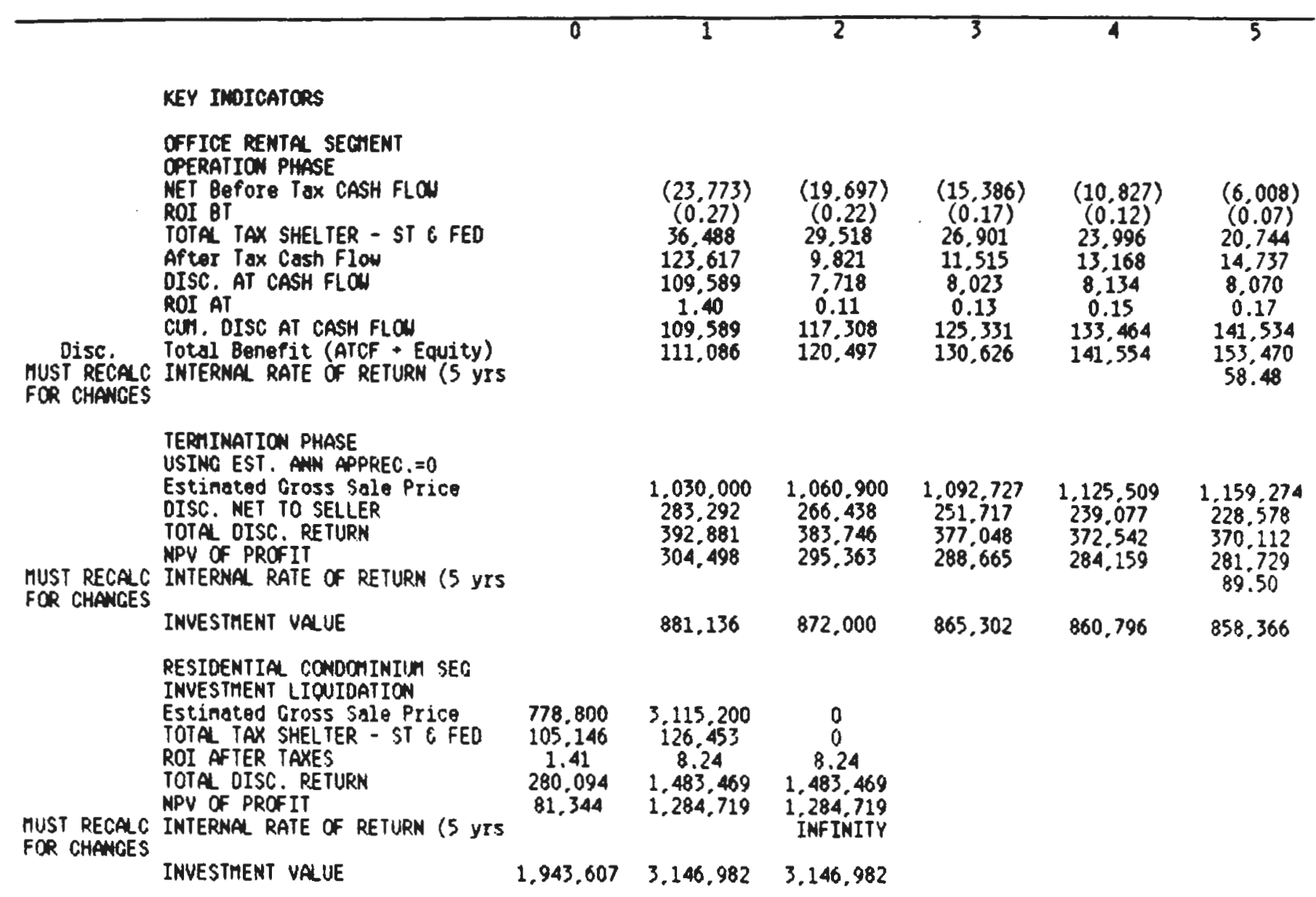


TOTAL PROJECT - RESIDENTIAL CONDOMINIUMS AND OFFICES

After viewing the residential and office segments, it is important to examine the project in total. The net present value of profit under all three scenarios is very high. This illustrates the project is yielding far in excess of the $12.8 \%$ required rate of return. Infact the NPV of the moderate and optimistic scenarios is over one million dollars.

The investment value also indicates that the project represents a financially sound undertaking. The investment value of the optimistic scenario, $\$ 4,005,348$ is over 1.5 million dollars greater than the actual cost of the project. The moderate and pessimistic scenario show an investment value of close to one million dollars over actual cost. Consequently, the project represents an excellent deal.

From all indications, it appears that the mixed use alternative represents a sound investment. If actual conditions approximate the moderate scenario, the investor can expect over one million dollars in excess of his $12.8 \%$ rate of return.

\section{F. Developer Assisted Mortgage Financing}

The market study revealed that a large percentage of potential buyers have the necessary income to meet mortgage payments but not the savings for a large down payment. Therefore, reducing the loan to value ratio may greatly improve marketability. The developer could accomplish this by buying down the initial equity requirement. However, because this is effectively decreasing the sales price of the units, this alternative must be weighed against the benefits of a shorter selling period.

The moderate scenario of the "condominiums only" alternative illustrates the benefits of a shorter selling period. All other factors remaining equal, but shortening the selling time to one year after construction, yields a total discounted return of $\$ 1,394,540$. This compares to $\$ 1,262,462$ if the selling period is two years. Consequently, the developer has the flexibility of using $\$ 132,078$ to buy down initial equity requirements if it appears he could cut the selling time in half.

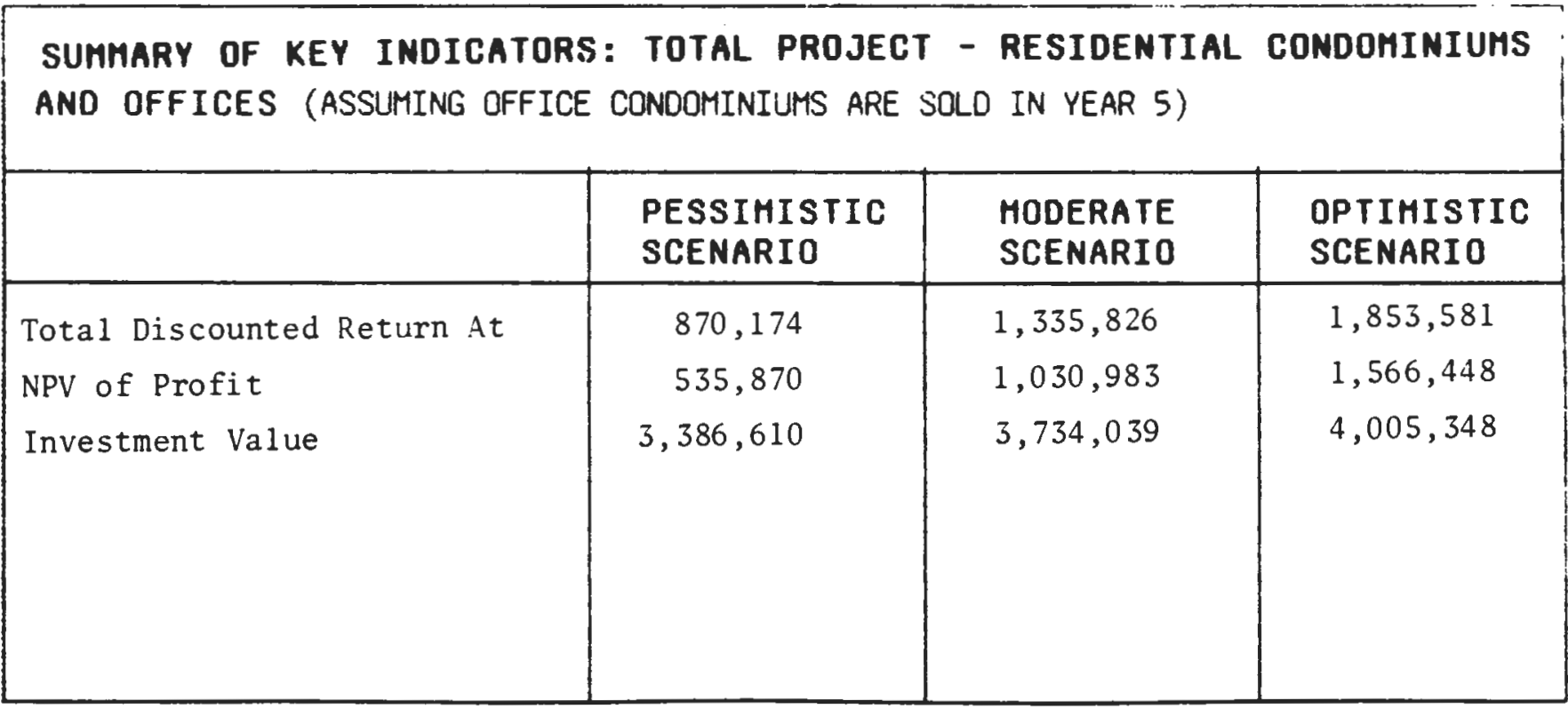


The same demonstration can be employed for the mixed use development. Shortening the selling period from $90 \%$ of the units being sold within 1 year after construction to $90 \%$ being sold within 6 months yields a total discounted return of $\$ 1,096,435$. This compares to $\$ 1,030,689$. This offers the developer $\$ 65,746$ for buy downs if it appears the selling period can be significantly decreased.

Consequently, it appears that the shorter selling period in both alternatives outweighs the benefits of a higher sales price to some degree. However, the decision to buy down initial equity requirements should not be made until the units go on the market. The decision should be made in light of how well the units sell during the pre completion stage and early months after construction. This financing opportunity should not be made available unless absolutely necessary to move units. First the developer should try to sell the units with no financing assistance. Next, sales should be attempted, offering the lowered down payment but with an inflated sales price to cover the cost of the buy downs. And lastly, the lowered initial equity requirements should be offered with the originally scheduled sales prices if the units are selling too slowly. 


\section{G. Final Recommendation For Optimum Development}

As clearly illustrated in the following table, the financial outcomes projected for the two development alternatives are quite similar. The moderate scenario of the mixed use development does exhibit a total discounted return of $\$ 1,335,826$, which is greater than that projected for the "codominiums only" alternative $(\$ 1,262,462)$. However, under the pessimistic and optimistic scenarios of the mixed use development, just the opposite relationship exists, the discounted returns are less (even though to a smaller degree) than in the "condominiums only" alternative.

With the key financial indicators so close, it is difficult to choose one of the two alternatives from pure$1 y$ a "bottom line" perspective. Both alternatives appear to be financially sound investments which promise healthy returns. Both alternatives also offer a similar degree of uncertainty (ie. the sales appeal of the first floor condominiums and market potential for office rentals). If forced to choose merely on the basis of indicators presented, the mixed use development alternative is the best option. Under the moderate scenario, which after all is the most likely, the project is expected to yield a discounted return approximately $\$ 73,000$ greater than the other alternative. This is significant enough to place favor with the mixed use alternative.

However, the most appropriate way to decide between the alternatives is with regard to the needs of the individual investor. If the investor wishes to make his profit quickly and be out of the deal, the "condominiums only" alternative makes the most sense. This alternative promises a good return without tying up resources for an extended period of time. On the other hand, if the investor expects income from other sources which he would like to shelter over the mext few years, the mixed use alternative would be the most suitable. This would allow the investor to make a rather large profit

\begin{tabular}{|l|c|c|c|}
\hline \multicolumn{3}{|c|}{ SUMMARY OF KEY INDICATORS } \\
\hline \multicolumn{1}{|c|}{$\begin{array}{c}\text { PESSIMISTIC } \\
\text { SCENARIO }\end{array}$} & $\begin{array}{c}\text { MODERATE } \\
\text { SCENARIO }\end{array}$ & $\begin{array}{c}\text { OPTIMISTIC } \\
\text { SCENARIO }\end{array}$ \\
\hline RESIDENTIAL CONDOMINIUMS ONLY & & \\
\hline Total Discounted Return & 843,215 & $1,262,462$ & $1,873,280$ \\
NPV of Profit & 578,215 & 997,462 & $1,608,280$ \\
Investment Value & $3,430,901$ & $3,726,925$ & $4,091,297$ \\
\hline CONDOMINIUMS ITH FIRST FLOOR OFFICES & & $1,335,826$ & $1,853,581$ \\
\hline Total Discounted Return & 870,174 & $1,030,983$ & $1,566,448$ \\
NPV of Profit & 535,870 & $3,734,039$ & $4,005,348$ \\
Investment Value & $3,386,610$ & & \\
\hline
\end{tabular}


initially but also to maintain ownership of the office segment to shelter income and sell at a later date.

In addition, regardless of the alternative chosen, developer assisted mortgage arrangements should be considered if the units begin to sell too slowly. As suggested in the preceeding section, this should first be attempted with inflated selling prices to cover the cost of the buy downs. If the units still do not move quickly enough the prices may be lowered. In most instances, this would still be in the best interest of the developer as the shorter selling period would outweigh the effects of the decreased sales prices. 


\section{Chapter VI Conclusion}

FINANCIAL BENEFIT TO THE INVESTOR

The Bancroft-Rice property exhibits tremendous potential for redevelopment. Both the residential and mixed use alternatives promise very high returns with a relatively small initial investment. The low purchase price of $\$ 265,000$ makes the site almost irresistible in light of the over $\$ 1.2$ million projected Total Discounted Return. Thi is allows a Net Present Value of approximately $\$ 1$ million.

As described in Chapter II, the Bancroft-Rice site is being sold as a package with two other somewhat less desirable schools $(\$ 265,000=$ total price for all three schools). However, the prospect of more than quardrupling the initial investment with the Bancroft project alone certainly compensates for the expected lower return from development at the other sites. It is evident that the City is very anxious to dispose of the property and has consequently severely under-priced it.

The recommended optimum development alternative is dependent on the needs of the perspective investor. The "condominiums only" alternative offers the best option for the investor who wishes to make his profit quickly and has no interest in remaining involved in the project. The Return on Investment forecasted for this option under the moderate scenario is well over $500 \%$ with an Internal Rate of Return over $400 \%$. Even if the units take two full years to sell and prices drop $10 \%$, the initial investment is still expected to more than triple. This option offers a high return without tying up resources for an extended period of time.

The mixed use alternative is recommended for the investor who needs a tax shelter over the next few years and is willing to maintain ownership of a portion of the project. This alternative would provide the investor a large profit initially (ie. well over $500 \%$ return on investment under the moderate scenario). It would also offer tax shelter benefits and an Investment Tax Credit equal to $20 \%$ of the rehabilitation costs. This also allows the investor to wait until the neighborhood property values have appreciated significantly and then sell at a high price. The Net Present Value of Profit under the moderate scenario is $\$ 1.03 \mathrm{mil}$ lion for the entire mixed use project.

As indicated in the financial analysis, regardless of which alternative is selected, shortening the selling time for the condominiums would generously increase profits. If the units begin to sell too slowly, the developer assisted mortgage financing suggested in Chapter $V$ should be instituted. This would increase the marketability of the units by reducing the down payment requirement.

TOTAL BENEFIT OF THE CITY OF BOSTON

This project, whether entirely residential or mixed use, will be very beneficial to the City. The school buildings, currently a neighborhood nuisance attracting vandalism and loitering, will be placed in service once again. The proposed rehabilitation promises an 
outstandingly attractive site, adding to the value of the immediate area. The project would also offer much needed high quality housing units without displacing a single current resident. All these indirect factors point to the potential positive impact of the project, however, the most striking benefit is the overwhelming revenue generated compared to the attributable municipal expenditures.

The fiscal impact analysis, detailed in Appendix E. clearly illustrates the project's direct financial benefit to the City. The four principal sources of public revenue are identified as departmental, state aid, federal aid and property tax. The projected increase in these revenue sources attributable to the residential project totals $\$ 136,678$. This figure contrasts with an increase in City expenditures of only $\$ 77,218$. The relatively small increase in necessary expenditures is primarily due to the expected lack of public education costs. The design of the units, market analysis, and description of the target population all indicate the probable absence of school aged children.

The comparison of revenues and expenditures shows that the project will much more than pay for its share of public services. The revenue, generated by the residential project is expected to be over one and a half times greater than its attributable municipal costs annually. The revenue to cost ratio of the mixed use alternative would be even larger. This is because the office segment would be taxed at a higher rate but most likely require less spent on public services.

\section{SUMMARY}

In total, the project offers considerable benefit to the City. The prospect of receiving almost two times as much revenue as would be expended appears to be a very attractive opportunity. These financial benefits coupled with the improvement of the site and lasting value added to the neighborhood would likely make the City amenable to sale.

The property also holds tremendous potential for the investor. The forecasted million dollar plus profit and small initial equity requirement makes this opportunity very difficult pass up. In addition, the successful completion of the project will establish credibility and may very well lead to other projects involving the adaptive reuse of public buildings. 
Appendices 
APPENDIX A.

\section{Regulation of Uses: $\mathrm{H}$ Zoning Districts}

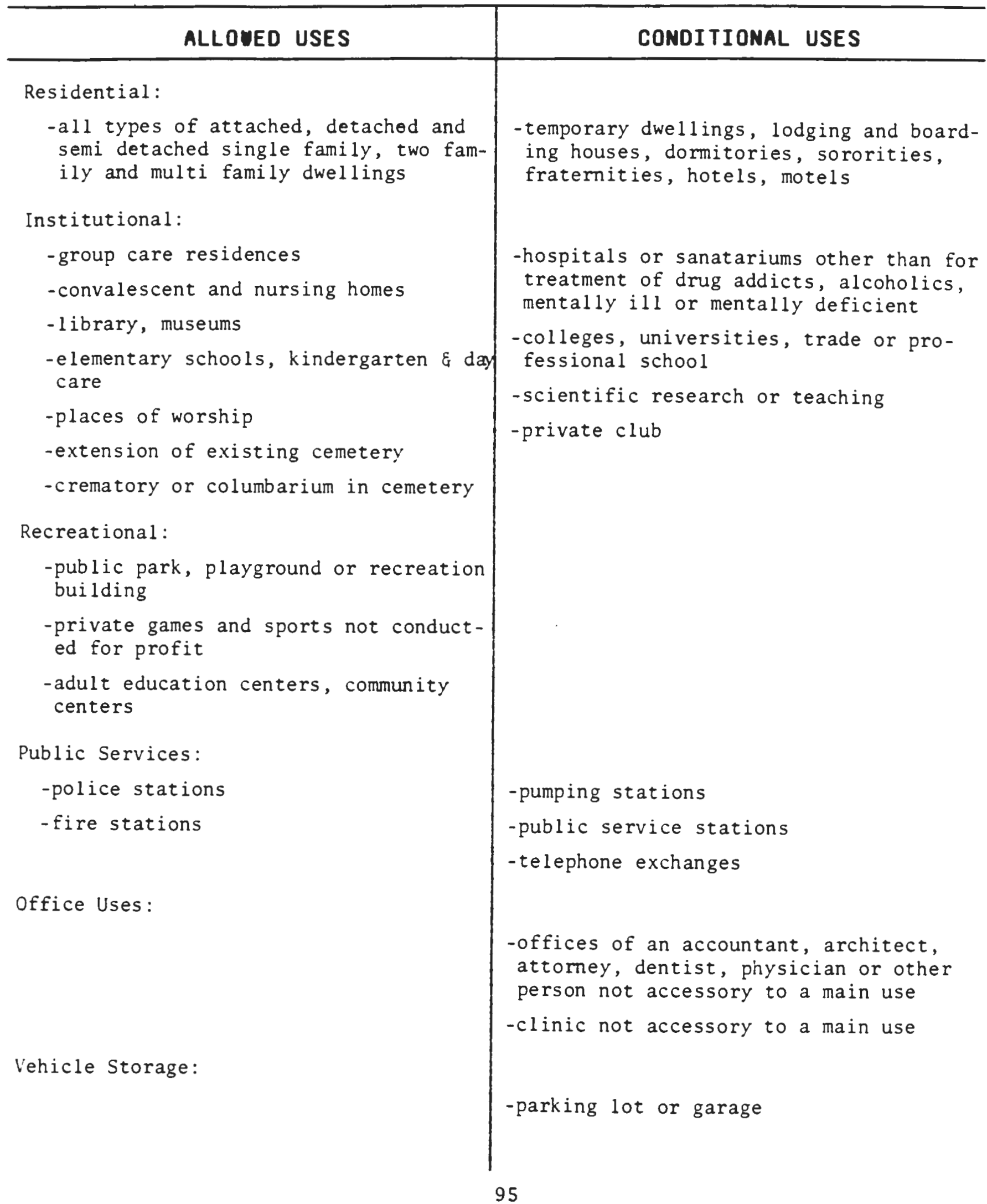




\section{Regulation of Uses: $\mathrm{H}$ Zoning Districts}

\begin{tabular}{l} 
ALLOUEO USES \\
\hline Accessory Uses: \\
- swimming pool or tennis court \\
- customary home occupation \\
- uses accessory to permitted office \\
occupant \\
- storage of flammable liquid or gas \\
- amusement games in sorority, frater- \\
nity or private club \\
- dwellings for personnel accessory to \\
main use \\
- as an accessory use to a building \\
with 50 dwelling units or more in a \\
hotel, barber shops, dining rooms, \\
news stands and similar establish- \\
ments primarily for the residents \\
thereof, when conducted wholly within \\
the building and entered solely from \\
within the structure
\end{tabular}

-keeping of animals for profit or labor-

atory research

\section{CONDITIONAL USES}


Dimensional Regulations

\begin{tabular}{|c|c|c|c|c|c|}
\hline \multicolumn{2}{|c|}{ REGULATION } & \multicolumn{2}{|c|}{$\begin{array}{l}\text { INTERPRETATION } \\
\text { FOR THE SITE }\end{array}$} & \multicolumn{2}{|c|}{ STATUS OF COMPLIANCE } \\
\hline & & Bancroft & Rice & Bancroft & Rice \\
\hline Lot siz Min. & None & None & None & C & C \\
\hline $\begin{array}{l}\text { Lot Area Min./ } \\
\text { Dwelling Unit }\end{array}$ & None & None & None & C & C \\
\hline Lot Width & None & None & None & C & C \\
\hline $\begin{array}{l}\text { Floor Area } \\
\text { Ratio }\end{array}$ & 3 & & & & \\
\hline $\begin{array}{l}\text { Lot Size X } \\
\text { F.A.R. } \\
=\text { Allowable }\end{array}$ & & $18,454 \times 3$ & $27,125 \times 5$ & & \\
\hline $\begin{array}{l}\text { Floor Area } \\
\text { (sq. ft.) }\end{array}$ & & $=55,362$ & $=81,375$ & $\begin{array}{l}\text { C, Allowable ad- } \\
\text { dition }=32,882 \\
\text { sq. ft. }\end{array}$ & $\begin{array}{l}\text { C, Allowable ad- } \\
\text { dition }=40,855 \\
\text { sq. ft. }\end{array}$ \\
\hline Max. Height & None & None & Yone & C & $\mathrm{C}$ \\
\hline $\begin{array}{l}\text { Front Yard Min. } \\
\text { Depth (ft.) }\end{array}$ & 15 & 15 & 15 & $\begin{array}{l}\text { NC, Need to apply } \\
\text { for Variance on } \\
\text { grounds that the } \\
\text { structure pre- } \\
\text { dates the Zoning } \\
\text { Code }\end{array}$ & $\begin{array}{l}\text { NC, Veed to apply } \\
\text { for Variance on } \\
\text { grounds that the } \\
\text { structure pre- } \\
\text { dates the Zoning } \\
\text { Code }\end{array}$ \\
\hline $\begin{array}{l}\text { Usable Open } \\
\text { Space: }\end{array}$ & & & & & \\
\hline $\begin{array}{l}\text { Min. sq.ft./ } \\
\text { Dwelling Unit }\end{array}$ & 100 & $100 / D . V$ & $100 / D . V$. & $\begin{array}{l}\text { Existing open } \\
\text { space including } \\
\text { area likely to } \\
\text { be used for park- } \\
\text { ing }=12,834 \text { sq. } \\
\mathrm{ft} .\end{array}$ & $\begin{array}{l}\text { Existing open space } \\
\text { including area like- } \\
\text { ly to be used for } \\
\text { parking }=16,777 \mathrm{sq} . \\
\text { ft. }\end{array}$ \\
\hline Unit & & $\begin{array}{l}\text { *may include } \\
\text { bal conies } \\
\text { and roofs }\end{array}$ & $=\begin{array}{l}\text { *may include } \\
\text { balconies } \\
\text { and roofs }\end{array}$ & & \\
\hline $\begin{array}{l}\text { Min. sq.ft./ } \\
\text { other use }\end{array}$ & Vone & None & None & C & C \\
\hline
\end{tabular}




\section{Dimensional Regulations}

\begin{tabular}{|c|c|c|c|c|c|}
\hline \multicolumn{2}{|c|}{ REGULATION } & \multicolumn{2}{|c|}{$\begin{array}{c}\text { INTERPRETATION } \\
\text { FOR THE SITE }\end{array}$} & \multicolumn{2}{|c|}{ STATUS OF COMPLIANCE } \\
\hline & & Bancroft & Rice & Bancroft & Rice \\
\hline $\begin{array}{l}\text { Rear Yard Min. } \\
\text { Depth ( } f t .)\end{array}$ & $10+\frac{L}{20}$ & $\begin{array}{l}10+\frac{115}{20} \\
=16\end{array}$ & $\begin{array}{l}10+\frac{70}{20} \\
=14\end{array}$ & C & C \\
\hline $\begin{array}{l}\text { Side Yard Min. } \\
\text { (ft.) }\end{array}$ & Vone & None & None & $\mathrm{C}$ & C \\
\hline $\begin{array}{l}\text { Setback of Par- } \\
\text { apet Min. Dis- } \\
\text { tance from Lot } \\
\text { Line (ft.) }\end{array}$ & $\frac{4+L^{1}}{6}$ & $\frac{45+120}{6}$ & $\frac{25+70}{6}$ & $\begin{array}{l}\text { NC, Need to apply } \\
\text { for Variance on } \\
\text { grounds struc- } \\
\text { ture predates } \\
\text { Zoning Code }\end{array}$ & $\begin{array}{l}\mathrm{NC} \text {, Need to apply } \\
\text { for Variance on } \\
\text { grounds structure } \\
\text { predates Eoning } \\
\text { Code }\end{array}$ \\
\hline $\begin{array}{l}\text { Rear Yard Yax. } \\
o \text { occupied by } \\
\text { Accessory } \\
\text { Buildings }\end{array}$ & 35 & 35 & 35 & $\begin{array}{l}\text { C, No accessory } \\
\text { buildings }\end{array}$ & $\begin{array}{c}\text { C, No accessory } \\
\text { buildings }\end{array}$ \\
\hline
\end{tabular}

\section{DIMENSIONAL REGULATIONS TABLE KEY}

$C=$ Currently in compliance with regulation

$\mathrm{NC}=$ Currently not in compliance with regulation

$\mathrm{L}=$ Length of wall parallel to lot line, measured parallel to lot line

$\mathrm{H}=$ Height of building above the height below which no setback is required

$\mathrm{L}^{1}=$ Length of wall parallel to lot line, measured parallel to lot line at greatest length above the height below which no setback is required 


\section{Points of Interest}

The school property's value is enhanced by its close proximity to many of Boston's parks, landmarks and other places of special interest. The following narrative and photographs depict a number of these attractive sites. The map illustrates their location in relation to the BancroftRice.

\section{Charles River Esplanade}

This park, dating from 1874, still serves as a valuable recreational resource. The mature vegetation and scenic lagoons provide a pleasant attractive atmosphere for passive and active recreation. The park contains dock facilities for many boaters. The Hatch Shell, an accoustic performance stage, is the focus of activity from May to September. The Boston Pops Orchestra, Boston Ballet and other groups perform free concerts which attract thousands annually. The existence of the park has protected the river from over-development and maintained it for public use. Magnificant views of the river have been preserved both for travelers along Storrow Drive and residents on Beacon Street.

\section{Boston Public Garden}

The Boston Public Garden is part of the famous park system designed by Frederick Law olmsted, the father of Landscape Architecture. The system provides a continuous chain of greenery affectionately named the "Emerald Necklace". The idea of the grand scheme was to allow garden paths from one end of the City to the other. The Public Garden today is one of the finest Darks in America. It serves as a flowering oasis in the heart of the City. It is particularly famous for its swan boats and monumental statuary The lively color accent provided by flowers and greenery are a welcome relief from the predominantly nuetral colors of the surrounding architecture

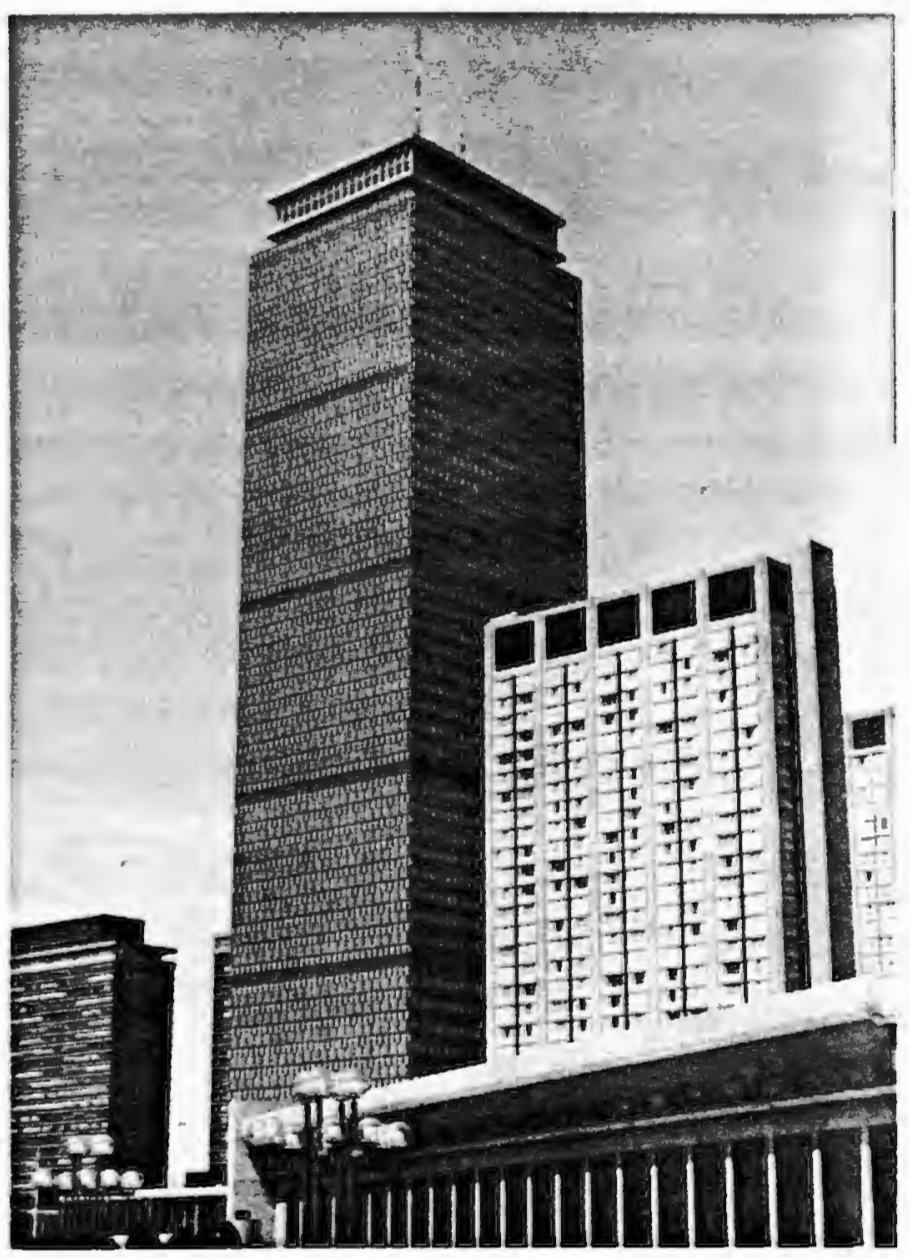

\section{Prudential Center (above)}

In comparison to other highlights of the area, the Prudential Center represents only a mediocre design. The stubby 52 story tower meets the sky abruptly, and is no match for the elegant John Hancock Building. However, the Center hosts many attractive components: the Sheraton Hotel, several restaurants, and many retail establishments including two large anchor stores.

\section{old South church (next page)}

The New old South Church is a splendid Boston Landmark. It was built in 1875 and designed in the Italian Gothic Style. Its pointed arches, polychromatic finish and car- 
ved ornamentation total a most impressive facade.

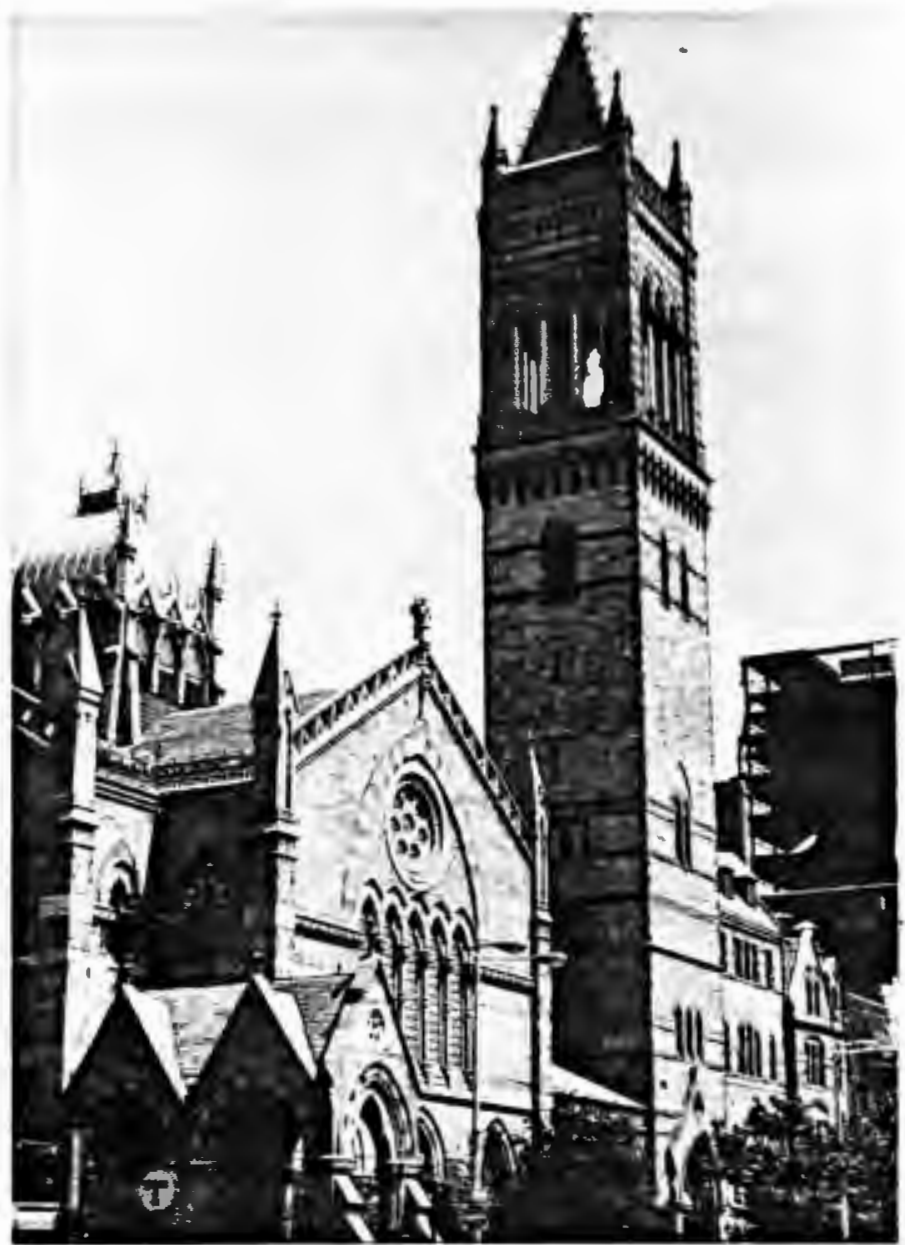

Trinity Church and Parish House

Trinity Church (1877) in Copley Square established Henry Hobson Richardson in the architectural world. It was his finest achievement and gained him world wide fame. This splended landmark was designed in the Romanesque Style with a Greek floor plan, represented by the square cross. Many of the attractive features of the church, characteristic of Richardson, include: double end columns, varying capitals, light and dark materials used together, beautifully carved motiffs and narrow grouped columnettes. The tower of the Church is also an interesting element. Its intricate niniature detail relieves what otherwise might be a very heavy feature.
The attractive Parish House immediately adjacent to Trinity Church was also designed by Richardson. The private garden, a unique feature in an urban church maintains almost "italian villa" characteristics, with its fountain, statuary and mazes of vegetation

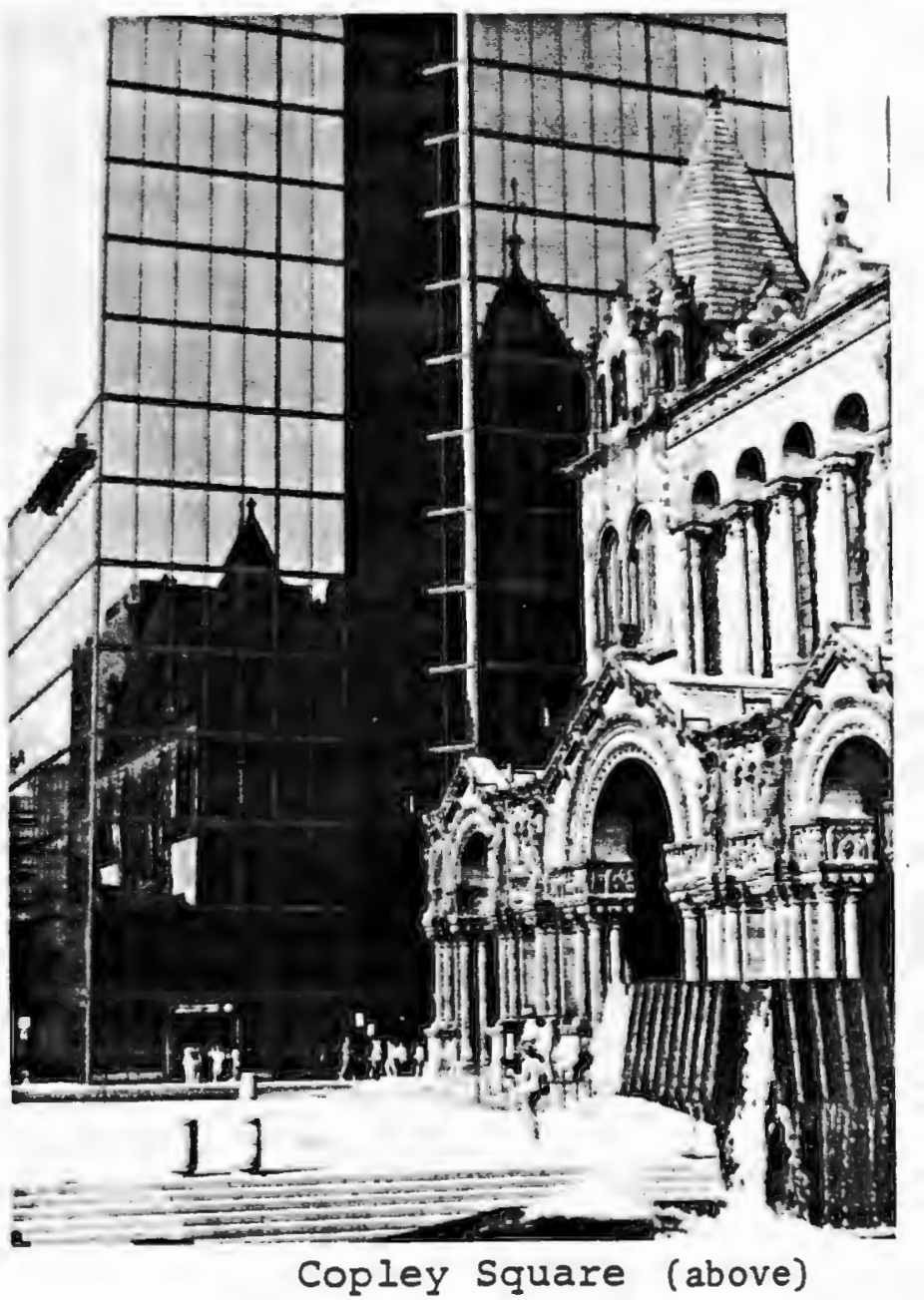

This plazza type courtyard links the Boston Public Library and Trinity Church. The attractive fountain provides a lively accent to the square.

Christian Science Center

The Christian Science Center headquarters of the church, contains a complex of buildings surrounding a magnificent reflecting pool. The structures are complemented by flower gardens and small trees. The original Mother Church was built in 1894. The church extension, constructed in 1906, 
is a grand domed limestone structure exhibiting Italian Renaissance and Byzantine influence. The Christian Science Publishing Society Building dates from 1935 and the three new structures were added in the early seventies. The abundance of white limestone and water in the complex makes the entire grouping of buildings seem to sparkle. The sitting areas and reflecting pool are used as open space for brown bag lunches or leisurely walks.

\section{Boston Public Library}

The handsome Boston Public Library houses an outstanding number of volumes and audio-visual materials. The original building was constructed in 1894 and designed in the grand Italian Renaissance Style. The Addition, completed in 1971 is also an attractive and compatible structure. The Library adds to the architectural integrity of the area as well as the educational benefits of the residents.

\section{New John Hancock (right)}

The unique parallelagram shaped tower was designed by I.M. Pei and constructed in 1969-72. The structure has been dubbed the "glass knife" illustrative of the elegant way the building meets the sky. As one drives around the City, the tower appears and disappears due to the unique shape and reflective glass. It provides beautiful mirror images of Trinity Church and the other attractive surrounding buildings. The grid iron arrangement of glass paines mimics the layout of blocks in the Back Bay, the only area of the City with parallel streets. The clean sleek design and predominance of glass minimizes the visual Mass of the building and proves to be a successful way to situate 62 floors on the site without overwhelming the surrounding area.

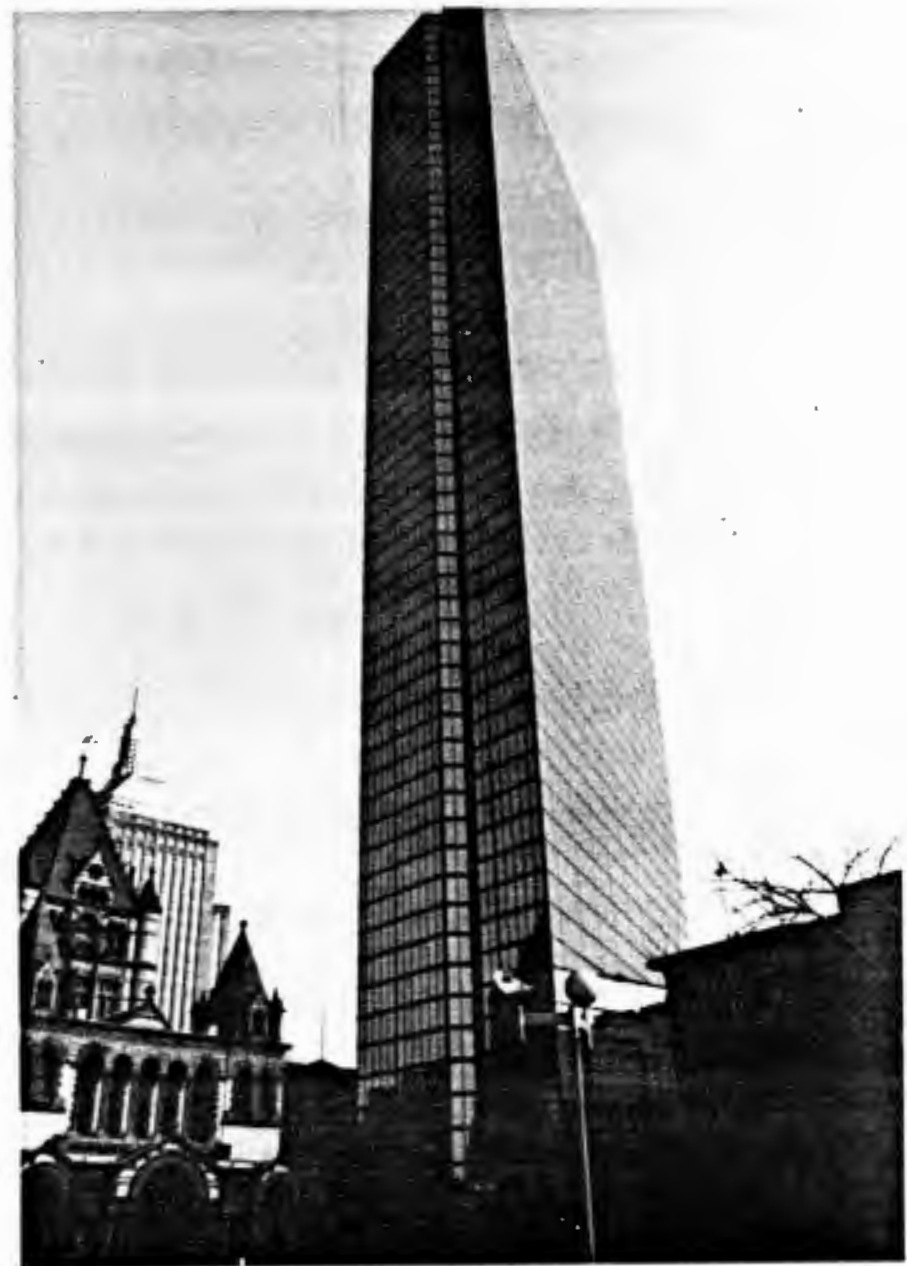

Copley Plaza Hotel

The Copley Plaza Hotel forms the South wall of Copley Square. The hotel was completed in 1912. Its style is elegant and tasteful. The facade is reminiscent of the grandiose massing of buildings in the French Academic tradition. The Hotel's restaurants, Grand Balls and Concerts entertain many visitors and residents. 


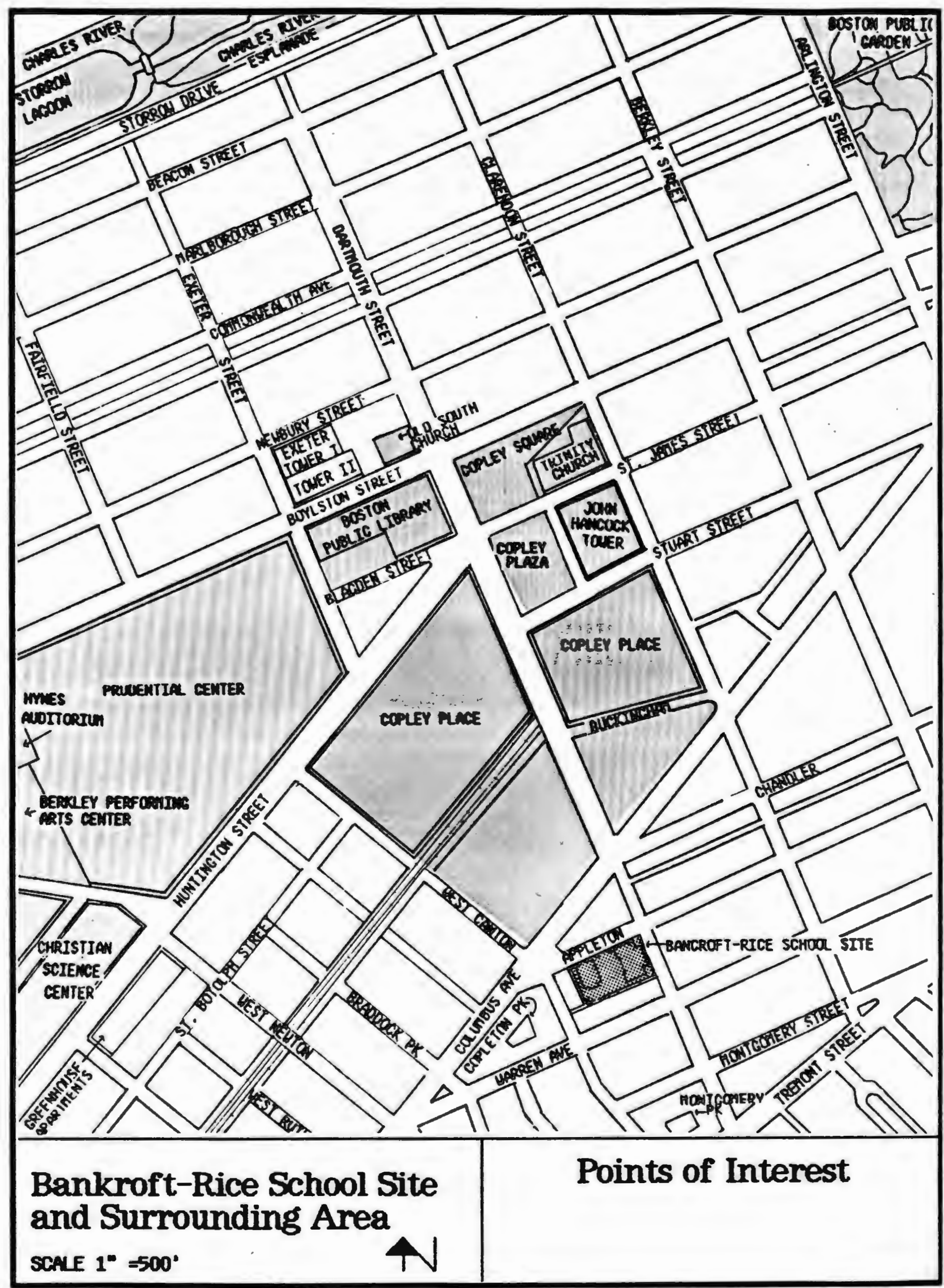




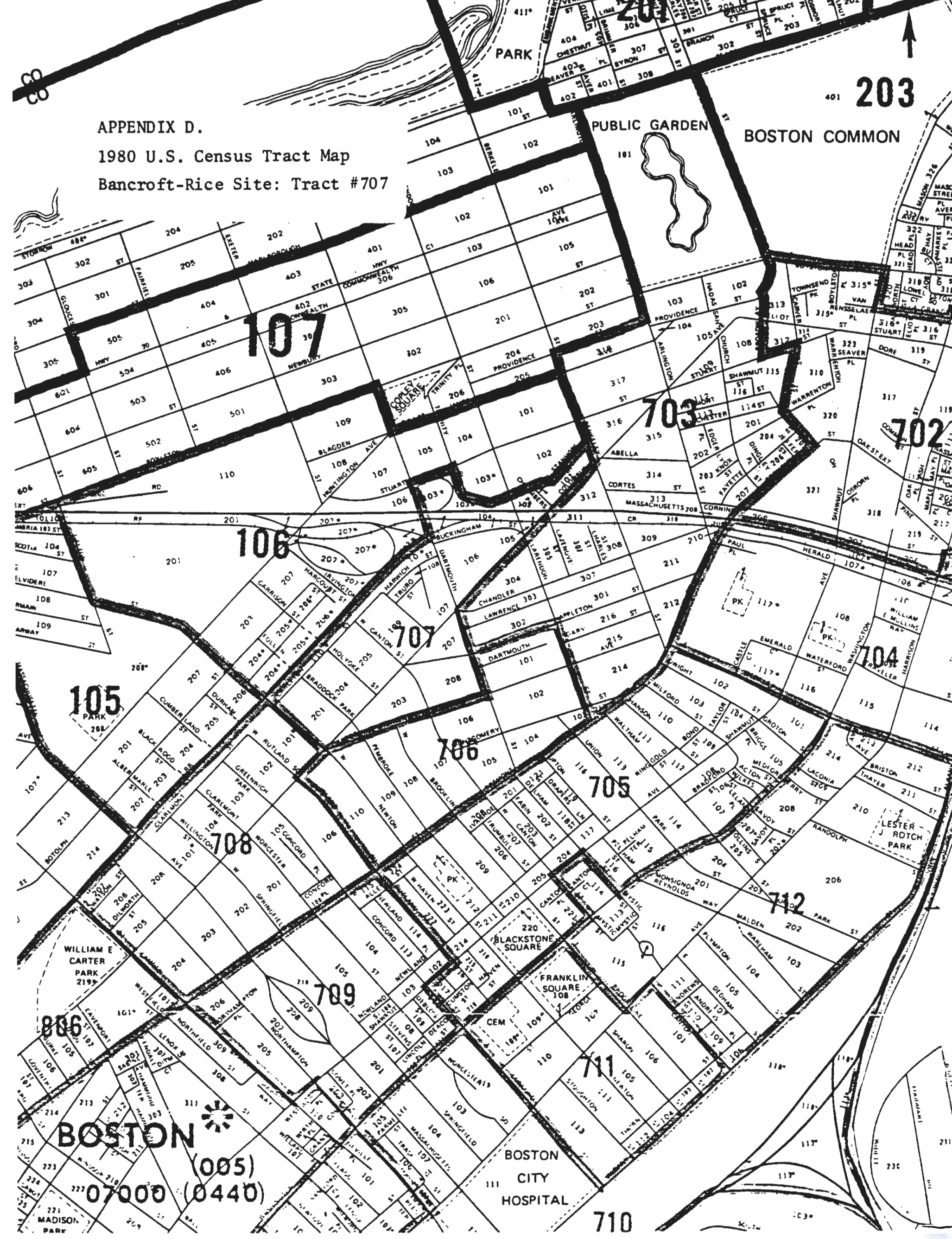


APPENDIX E.

\section{Fiscal Impact Analysis}

\section{PROJECT SUMMARY}

Project market value

Additional population (Residential only)

Additional school enrollment (Residential only)

\section{REVENUE FORECAST SUMMARY}

$\begin{array}{llr}\text { Revenue } & \text { Current Revenues } & \text { Revenue Incr } \\ \text { Departmental* } & \$ 199,700,000.00 & \$ 28,376.86 \\ \text { State Aid } & \$ 190,100,000.00 & \$ 27,012.72 \\ \text { Fed. Aid } & \$ 18,500,000.00 & \$ 2,628.80 \\ \text { Project-Related Property Tax Rev. } & \$ 78,660.00 \\ \text { Additional Project Revenues } & \$ & 0.00 \\ \text { TOTAL PROJECT-RELATED REVENUES } & \$ 136,678.40\end{array}$

\section{PER CARITA COSTING METHOD SUMMARY}

Total municipal expenditures

Total school expenditures

Residential share of local tax base:

Non-residential refinement coeff.:

Residential expenditures

Per capita residential expenditures

Per student school expenses

Forecast municipal exp. growth

Forecast school exp. growth

TOTAL forecast exp. growth

TOTAL forecast revenue growth

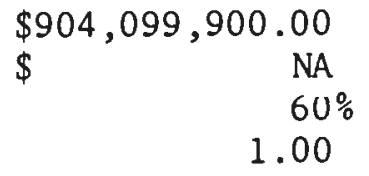

1.00

$\$ 542,459,940.00$

$\$ 963.52$

NA

$\$ \quad 77,081.00$

$\$ \quad 0.00$

$\$ \quad 77,081.00$

$\$ 136,678.00$

\section{BALANCE: REVENUES COMPARED TO EXPENDITURES $\$ 59,597.00$}

*Departmental includes city, health and hospitals, parking meters, parking fines, payments in lieu of taxes, interests on investments, and other revenues. 


\section{End Notes}

1. Boston Public Facilities Department, "Design and Development Guidelines, Surplus School Buildings".

2. Massachusetts Bay Transportation Authority, 1976. South West Corridor Development Plan.

3. Boston Inspectional Services Department, 1983. Boston Zoning Code and Enabling Legislation (as assembled through June 30, 1983).

4. Survey of Area Realtors:

AES Realty, Boston, Massachusetts.

AE Rondeau Realty, Boston, Massachusetts.

Betty Gibson Associates, Boston, Massachusetts.

Century 21 Cityside, Boston, Massachusetts.

Copley Square Associates, Boston, Massachusetts.

58 Charles Street Associates, Boston, Massachusetts.

Urban Renaissance Properties, Boston, Massachusetts.

5. Ibid.

6. Ibid.

7. Ibid.

8. Raw Data Sources: Boston Activities Budget, 1984,. Boston Department of Tax Assessment,. Boston Department of Budget.

Information sources for charts and graphs are noted on the figures. 


\section{Bibliography}

Barrett, G. Vincent and Blair. John P., 1982. How to Conduct and Analyze Real Estate Market and Feasibility Studies. New York: Van Nostrant Reinhold Company.

Boston Inspectional Services Department, 1983. Boston Zoning Code and Enabling Legislation (as assembled through June 30, 1983).

Boston Public Facilities Department, "Design and Development Guidelines, Surplus School Buildings".

Lynn, Theodore S. and Goldberg, Harry F, 1976. Real Estate Limited Partnerships. New York: John Wiley and Sons, Inc.

Maisel, Sherman J. and Ronlac, Stephen E., 1976. Real Estate Investment and Finance. New York: McGraw Hill.

Massachusetts Bay Transportation Authority, 1976. South West Corridor Development Plan.

Reynolds, Henry, 1984. Home-Tech Remodeling and Renovation Cost Estimator, Volume 1 Field Manual. Bethesda, Maryland: Home-Tech Publications.

United States Census Bureau, 1960. Census of Population and Housing.

United States Census Bureau, 1970. Census of Population and Housing.

United States Census Bureau, 1980. Census of Population and Housing.

Weimer, Arthur M., Hoyt, Homer ana Bloom, George F., 1972. Real Estate. New York: Ronald Press Company. 